\title{
Antioxidants: Classification, Natural Sources, Activity/Capacity Measurements, and Usefulness for the Synthesis of Nanoparticles
}

\author{
Jolanta Flieger $^{1, *(\mathbb{D},}$, Wojciech Flieger ${ }^{2}\left(\mathbb{D}\right.$, Jacek Baj ${ }^{2} \mathbb{D}$ and Ryszard Maciejewski ${ }^{2} \mathbb{D}$ \\ 1 Department of Analytical Chemistry, Medical University of Lublin, Chodźki 4A, 20-093 Lublin, Poland \\ 2 Chair and Department of Anatomy, Medical University of Lublin, Jaczewskiego 4, 20-090 Lublin, Poland; \\ wwoj24@gmail.com (W.F.); jacek.baj@umlub.pl (J.B.); ryszard.maciejewski@umlub.pl (R.M.) \\ * Correspondence: j.flieger@umlub.pl; Tel.: +48-81448-7182
}

Citation: Flieger, J.; Flieger, W.; Baj, J.; Maciejewski, R. Antioxidants:

Classification, Natural Sources, Activity/Capacity Measurements, and Usefulness for the Synthesis of Nanoparticles. Materials 2021, 14, 4135. https://doi.org/10.3390/ ma14154135

Academic Editor: Benjamin Solsona

Received: 18 June 2021

Accepted: 23 July 2021

Published: 25 July 2021

Publisher's Note: MDPI stays neutral with regard to jurisdictional claims in published maps and institutional affiliations.

Copyright: (c) 2021 by the authors. Licensee MDPI, Basel, Switzerland. This article is an open access article distributed under the terms and conditions of the Creative Commons Attribution (CC BY) license (https:// creativecommons.org/licenses/by/ $4.0 /)$.

\begin{abstract}
Natural extracts are the source of many antioxidant substances. They have proven useful not only as supplements preventing diseases caused by oxidative stress and food additives preventing oxidation but also as system components for the production of metallic nanoparticles by the so-called green synthesis. This is important given the drastically increased demand for nanomaterials in biomedical fields. The source of ecological technology for producing nanoparticles can be plants or microorganisms (yeast, algae, cyanobacteria, fungi, and bacteria). This review presents recently published research on the green synthesis of nanoparticles. The conditions of biosynthesis and possible mechanisms of nanoparticle formation with the participation of bacteria are presented. The potential of natural extracts for biogenic synthesis depends on the content of reducing substances. The assessment of the antioxidant activity of extracts as multicomponent mixtures is still a challenge for analytical chemistry. There is still no universal test for measuring total antioxidant capacity (TAC). There are many in vitro chemical tests that quantify the antioxidant scavenging activity of free radicals and their ability to chelate metals and that reduce free radical damage. This paper presents the classification of antioxidants and non-enzymatic methods of testing antioxidant capacity in vitro, with particular emphasis on methods based on nanoparticles. Examples of recent studies on the antioxidant activity of natural extracts obtained from different species such as plants, fungi, bacteria, algae, lichens, actinomycetes were collected, giving evaluation methods, reference antioxidants, and details on the preparation of extracts.
\end{abstract}

Keywords: antioxidants; natural extracts; antioxidant activity/capacity; green synthesis; nanoparticles

\section{Introduction}

Recently, much research has been devoted to free radical chemistry. There are undeniable pieces of evidence that free radicals are responsible for the oxidative damage of biomolecules such as proteins, lipids, or nucleic acids in the structures of cell nuclei and molecular membranes. Maintaining the balance between free radicals and antioxidants is a prerequisite for staying healthy. Thus, the control of oxidative stress processes may turn out to be fundamental in both the prevention and treatment of many diseases, such as diabetes, atherosclerosis, coronary artery disease, cancer, inflammation, liver diseases, cardiovascular diseases, cataracts, nephrotoxicity, and neurodegenerative processes accompanying aging. In order to maintain redox homeostasis, excess free radicals are neutralized by enzymes and non-enzymatic antioxidants, which, with the exception of a few produced by the human body, e.g., glutathione, uric acid, and uricinol, must be supplied with the diet. Since synthetic antioxidants butylated hydroanisole (BHA), butylated hydrotoluene (BHT), n-propyl gallate (PG) pose a potential health risk due to contamination with chemical precursors, toxic solvents, and the formation of hazardous by-products, natural antioxidants are an attractive alternative. For this reason, there is an extensive search for effective, non-toxic, and natural antioxidants. According to PubMed, in the last 5 years, over three thousand review articles that prove the effectiveness of natural antioxidants in preventing 
diseases caused by oxidative stress have been published. Therefore, antioxidants have become co-adjuvants utilized in conventional therapies with the aim of combating oxidative stress. Many natural antioxidants have been shown to have strong antiviral effects. The efficacy of flavonoids, i.e., (+)—catechin, luteolin, apigenin, quercetin, and quercetin 7-rhamnoside, has been proven in coronavirus infections (Porcine epidemic diarrhea virus (PEDV), Transmissible gastroenteritis virus (TGEV) [1-3]. In the absence of effective therapies for the treatment of diseases caused by coronaviruses, antioxidants may prove to be an effective alternative to fight the SARS- and MERS-CoV pandemic [4]. The site of action of antioxidants is the oxidative stress pathway, which plays a key role in coronavirus-induced pathogenesis. Diniz et al. [4] reviewed different effects of natural antioxidants against coronavirus covering reduction nucleocapsid $(\mathrm{N})$ protein expression, inhibition 3C-like protease (3CLpro) [5-8] enzyme responsible for replication of SARS-CoV (quercetin and its derivatives), papain-like protease (PLpro) (isobavachalcone and psoralidin) [9], and helicase protein by affected ATPase activity (myricetin and scutellarein) [10]. A recently published review demonstrated the usefulness of antioxidants in the treatment of neurological disorders caused by COVID-19 [11]. However, reports that do not confirm the effectiveness of antioxidants in vivo cannot be ignored [12]. The activity of antioxidants is mainly limited by ADMET (Absorption, Distribution, Metabolism, Excretion, and Toxicology)processes related to poor absorption caused by restrictions in the penetration of cell membranes and degradation that occurs in the stomach and intestines. It has also been reported that low molecular weight antioxidants lose their ability to scavenge free radicals inside cells. This is especially true for the scavenging of the hydroxyl radical $\left(\mathrm{OH}^{\bullet}\right)$, superoxide $\left(\mathrm{O}_{2}{ }^{\bullet-}\right)$, and $\mathrm{H}_{2} \mathrm{O}_{2}[13,14]$.

The sources of natural antioxidants are mainly plants, i.e., edible vegetables, fruits, spices, and herbs, which are rich in vitamins, phenolic compounds, carotenoids, and microelements [15-17]. However, it should be emphasized that the antioxidant activity is different for different varieties and morphological parts of natural resources. In addition, the activity of natural products is influenced by many other factors, such as climatic and soil conditions or harvest time. They hinder the standardization of natural products to a large extent. Due to the fact that natural antioxidants have the ability to inhibit the processes of oxidation and the growth of microorganisms, including many pathogenic ones, e.g., Salmonella spp. and Escherichia coli [18], they are more and more often used as preservatives in food products [19] or as packaging ingredients for food [20]. In recent years, a large body of evidence has been published that natural antioxidants increase the stability of edible oils [21-23], the stability of carotenoid dyes, and the aroma of fruit juices [24] and that they work well as additives in meat products [25,26] and even in bakery products [27], successfully replacing artificial preservatives and stabilizers. It should be emphasized that the choice of bioactive compounds for the food industry is significantly limited due to the obvious taste requirements [28] and the need for approval by EFSA (European Food Safety Authority) or FDA (American Food and Drug Administration). Currently, we can observe an interesting trend in the strategy of using by-products of the processing industry $[29,30]$. This is related not only to environmental protection or economic reasons but to the fact that they have a significant content of bioactive substances, exceeding that in the flesh of fruit, such as polyphenols in apple and olive pomace [31], lycopene in tomato pomace [32], phenolic compounds from the group of flavonoids (anthocyanins, catechins), and phenolic acids and stilbenes in grape skins [33] or citrus fruits [34].

In recent years, natural extracts have become attractive, also due to the rapid development of nanotechnology. As a source of substances with reducing potential, they have replaced the toxic reagents used in chemical synthesis and ushered in the era of the so-called biogenic synthesis and nanobiotechnology [35].

Numerous spectroscopic, biochemical, and electrochemical assays are used to test antioxidant abilities, which are still modified so that they can effectively assess the potential of antioxidants, taking into account the variability of their mechanisms of action. They are usually based on a free radical scavenging reaction or the prevention of their formation by 
the addition of an antioxidant. Various techniques used for this purpose differ in terms of repeatability and costs associated with the necessity of using specialized equipment. Valuable reviews, published in recent years, describe problems related to (i) the mechanisms responsible for the antioxidant activity [17]; (ii) the antioxidant activity of natural extracts prepared from various plant species [36], microorganisms [37], and food ingredients [38]; and (iii) the preventive role of antioxidants in various diseases such as diabetes [39], human gut diseases [40], and cancer [41], as well as the use of natural extracts for the synthesis of nanoparticles [42].

This review gathers together issues related to antioxidants (classification, natural sources, measurement of antioxidant activity) as well as their application in nanotechnology. Within the review, two main issues can be distinguished:

(i) The wide range of industrial and biomedical applications of antioxidants requires effective and rapid in vitro tests to evaluate total antioxidant activity. Various methods were collected in the review, i.e., chromatographic, spectrometric, and electrochemical. Particular attention was paid to the method based on metallic nanoparticles, which are used as optical probes (SNPAC). The method is useful for measuring the antioxidant activity of both simple chemical compounds and mixtures of natural origin. The SNAPC tests are effective in assessing electron transfer but are not used very often. The review includes information on the extracts from plants, lichens, fungi, algae, and actinomycetes (reference antioxidants, extraction process, antioxidant activity tests, and activity parameters).

(ii) Natural extracts as a source of both reducing and stabilizing substances are used for the green synthesis of nanoparticles. The review includes examples of the synthesis of metallic/metal oxides of nanoparticles using extracts from various plant species and microorganisms (yeast, algae, cyanobacteria, fungi, and bacteria). The information collected allows us to trace the links between the type of antioxidant, its origin, activity, and suitability for the efficient synthesis of nanoparticles. Extensive data were collected on the methods of extract preparation, antioxidant activity tests, detection methods, NPs synthesis conditions, and the morphology of the obtained nanoparticles.

This review highlights recent trends in antioxidant research, measurement of antioxidant activity, biogenic nanoparticle synthesis, and nano-drug delivery systems.

\section{Free Radicals/Antioxidants}

\subsection{Free Radicals vs. Oxidative Stress}

Free radicals can be defined as highly reactive species that contain an unpaired electron in the valence shell. They can donate this electron but also accept it from other molecules, acting as an oxidant or reducing agent [43]. In the human body, reactive forms (RS) come from metabolic processes involved in the respiratory chain, phagocytosis, prostaglandin synthesis, and the cytochrome P-450 system [44].

The most reactive species found in biological systems include the hydroxyl radical $\left(\mathrm{OH}^{\bullet}\right)$, which is formed by attaching three electrons to an oxygen molecule, e.g., as a result of the Fenton reaction, and the superoxide radical $\left(\mathrm{O}_{2}{ }^{\bullet-}\right)$, which is formed mainly in mitochondria, as a byproduct of electron transport in the respiratory chain. Other reactive forms of oxygen (ROS), nitrogen (RNS), and chlorine occurring as free radicals and nonradicals that as oxidizing agents can be easily converted into radicals are listed in Table $1[45,46]$. 
Table 1. Examples of reactive species. Reproduced with permission from Graves, D.B., [J. Phys. D Appl. Phys.]; published by IOP Publishing, 2012 [47].

\begin{tabular}{|c|c|c|}
\hline Reactive Species & Form & Example \\
\hline $\begin{array}{l}\text { Reactive oxygen } \\
\text { species (ROS) }\end{array}$ & $\begin{array}{l}\text { Radical } \\
\text { Non-radical }\end{array}$ & $\begin{array}{l}\mathrm{HO}^{\bullet},{ }^{1}[\mathrm{O}]_{2}, \mathrm{O}_{2}{ }^{\bullet-} \mathrm{HOO} \bullet, \mathrm{ROO}^{\bullet}, \mathrm{RO}^{\bullet}, \mathrm{CO}_{2}^{\bullet-}, \mathrm{CO}_{3}^{\bullet-} \\
\mathrm{O}_{3}, \mathrm{H}_{2} \mathrm{O}_{2}, \mathrm{HOCl}, \mathrm{HOI}, \mathrm{HOBr}, \mathrm{ROOH}, \mathrm{CO}, \mathrm{ONOOH}, \\
\mathrm{ONOO}^{-}, \mathrm{O}_{2} \mathrm{NOO}^{-}, \mathrm{HOOCO}_{2}^{-},\left(\mathrm{O}_{2} \mathrm{1Dg}\right)\end{array}$ \\
\hline $\begin{array}{l}\text { Reactive nitrogen } \\
\text { species (RNS) }\end{array}$ & $\begin{array}{l}\text { Radical } \\
\text { Non-radical }\end{array}$ & $\begin{array}{l}\mathrm{NO}^{\bullet}, \mathrm{NO}_{2}^{\bullet}, \mathrm{NO}_{3}^{\bullet} \\
\mathrm{ROONO}, \mathrm{RO}_{2} \mathrm{ONO}, \mathrm{CH}_{3} \mathrm{C}(\mathrm{O}) \mathrm{OONO}_{2}, \\
\mathrm{~N}_{2} \mathrm{O}_{4}, \mathrm{~N}_{2} \mathrm{O}_{3}, \mathrm{~N}_{2} \mathrm{O}_{5}, \mathrm{HNO}_{2} \mathrm{NO}_{2} \mathrm{Cl} \mathrm{NO}^{-}, \mathrm{NO}^{+}\end{array}$ \\
\hline $\begin{array}{l}\text { Reactive } \\
\text { chlorine species }\end{array}$ & $\begin{array}{l}\text { Radical } \\
\text { Non-radical }\end{array}$ & $\begin{array}{l}\mathrm{Cl}^{\bullet} \\
\mathrm{ClBr}, \mathrm{Cl}_{2}, \mathrm{ClO}_{2}\end{array}$ \\
\hline Reactive sulfur species & $\begin{array}{l}\text { Radical } \\
\text { Non-radical }\end{array}$ & $\begin{array}{l}\mathrm{S}^{\bullet} \\
\mathrm{H}_{2} \mathrm{~S}, \mathrm{RSSR}, \mathrm{RS}(\mathrm{O}) \mathrm{SR}, \mathrm{RSOH}, \mathrm{RS}(\mathrm{O})_{2} \mathrm{SR}, \mathrm{RSR}^{\prime}\end{array}$ \\
\hline
\end{tabular}

ROS/RNS generated in oxygen metabolism are necessary in the regulation of gene expression, cell proliferation, apoptosis, the processes of protein phosphorylation or calcium concentration in cells, activation of proteins controlling cell division, and elimination of microorganisms. Free radicals are also generated under the influence of external sources, such as exposure to X-rays, ozone, smoking, air pollution, and industrial chemicals [48,49]. There is a balance in the cell between RS production and its neutralization by defense systems. Under physiological conditions, this balance is slightly shifted in favor of pro-oxidative conditions, providing continuous, mild oxidative stress [50].

Each disturbance of this particular balance may lead to the development of oxidative stress, i.e., a state in which the oxidizing potential increases to a level that threatens the stability of cellular structures [51]. Under oxidative stress, biologically important macromolecules such as DNA, proteins, carbohydrates, and lipids are damaged. The excess of free radicals changes their structure and thus the physiological functioning of the cell by disrupting redox signaling and the accumulation of cytotoxic compounds, such as malonyl dialdehyde or 4-hydroxynonenal [52,53].

There is evidence that free radicals can accumulate throughout the body with age, initiating the aging process, as well as various neurodegenerative diseases such as Alzheimer's disease, Parkinson's disease, muscular dystrophy, and atherosclerosis [54]. An imbalance between ROS and the antioxidant defense system has also been recognized in the induction of diabetes and age-related eye disease [55]. Currently, it is believed that oxidative stress has a significant negative impact also on inflammatory diseases, cancer, ischemic diseases, immunodeficiency syndrome, hypertension, alcoholism, smoking-related diseases, and many others [56-61]. Oxidative stress was first described and defined by Sies in 1991 [62].

The reasons for the occurrence of oxidative stress may be (i) an increase in the rate of ROS production, (ii) deficiencies of low-molecular-weight antioxidants, and (iii) inactivation of enzymes with antioxidant activity. Increased and/or prolonged state of oxidative stress may cause serious damage to the cell and even lead to its death [63]. Therefore, the current discussions focus on the role of free radicals in the pathogenesis of many diseases and the usefulness of antioxidants in their potential therapy [55,64,65].

Antioxidants are produced by the protective system of various organisms in order to respond to the destructive effects of free radicals. Antioxidants are able to reduce the damage caused by ROS/RNS and even chlorine. The action of the protective system may limit the negative effects of free radicals by preventing the formation of reactive radicals or by interrupting free radical reactions [66].

\subsection{Antioxidants}

Antioxidants act by delaying or preventing the oxidation of other chemicals. The first studies on the role of antioxidants in biology focused on their use in preventing unsaturated fats from going rancid [67-69]. However, the milestone that led to the understanding of the 
role of antioxidants for living organisms was the identification of vitamins A, C, and E [70] and the understanding of the mechanism of lipid peroxidation prevention by vitamin $\mathrm{E}$ [71]. The classification of antioxidants, along with the most representative examples, is shown in the diagram (Figure 1). Antioxidants are usually classified into enzymatic and nonenzymatic. Among them, there are various compounds with different modes and places of action and different final effects. This diversity determines the individual role of each of them in the body. It should be emphasized that the network of interacting antioxidant enzymes, such as superoxide dismutase enzymes (SODs), catalase (CAT), glutathione peroxidase (GPx), and glutathione reductase (GRd), shows the highest antioxidant defense effectiveness [72].

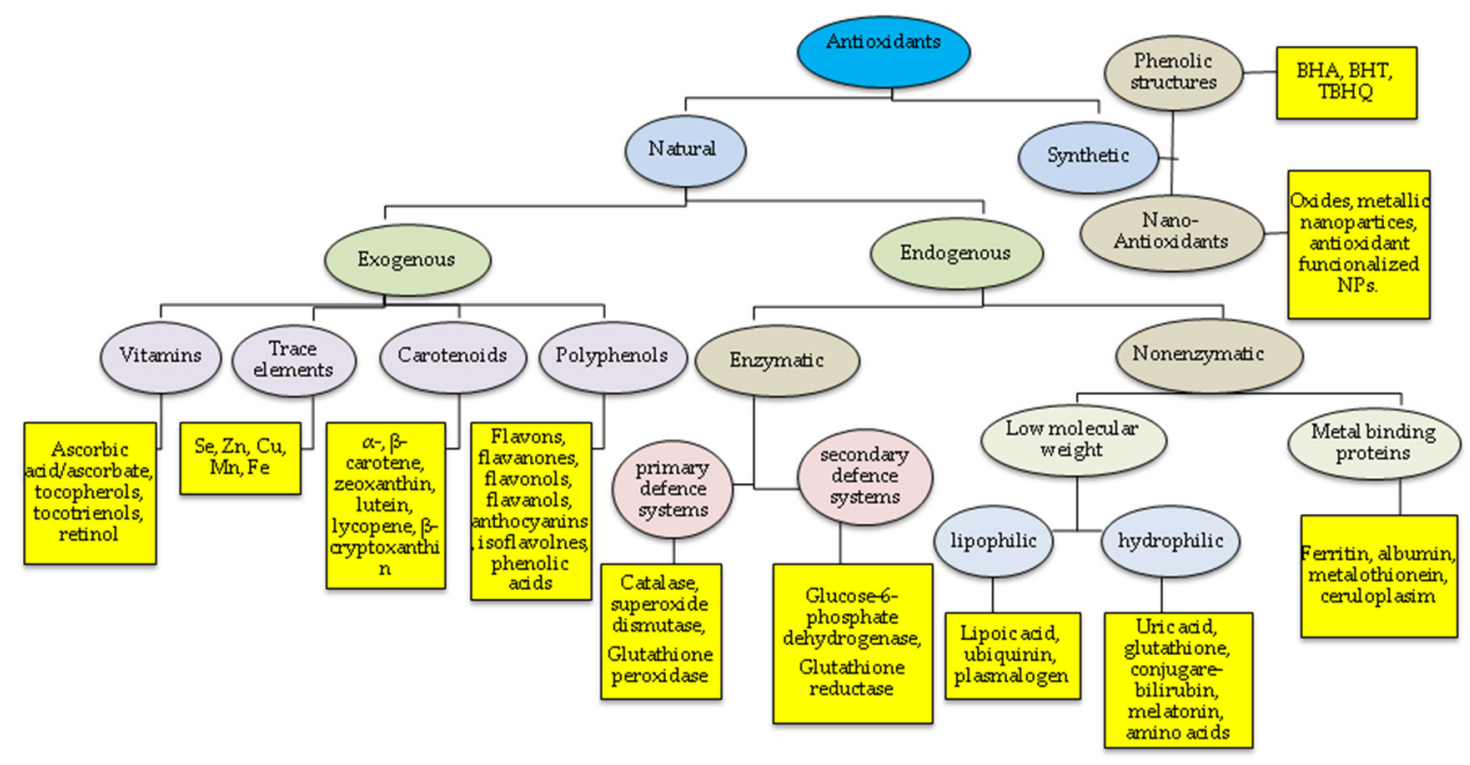

Figure 1. Antioxidants classification.

Low-molecular-weight antioxidants, including vitamin C, E, coenzyme $Q$, carotenes, glutathione, and trace elements, are also responsible for inactivating reactive radicals. Some of them, including glutathione, ubiquinone, albumin and metallothioneins, and uric acid, are produced in the body [73], but most are exogenous compounds derived from natural sources such as plants (flavonoids, phenolic acids, carotenoids, stilbenes, coumarins, lignans, organosulfur compounds, vitamins) or minerals (selenium, zinc, manganese) provided with the diet. When endogenous antioxidants involved in free radical defenses cannot protect the body against ROS, there is a need for exogenous antioxidants. Almost all living organisms, both prokaryotes and eukaryotes, are capable of producing bioactive compounds.

Many of the naturally occurring antioxidants are now isolated, fully characterized, and available for various applications as prophylactic and therapeutic agents to inhibit the adverse effects generated by ROS [74,75].

A good diet that includes fruit, tea, wine, vegetables, and grains is a rich source of antioxidants. Some drugs, apart from their therapeutic effect, also have antioxidant effects, e.g., captopril belonging to angiotensin-converting enzyme (ACE) inhibitors, Nacetylcysteine [76], or dihydropyridine calcium antagonists [77]. However, the concentrations used in the therapy do not provide antioxidant activity in vivo.

The source of antioxidants and other bioactive compounds are also microorganisms, including actinomycetes, bacteria [78], cyanobacteria, fungi, and lichens [79]. Compared to plants, these organisms can grow very quickly under strictly controlled conditions, which makes them a favorable source of natural bioactive molecules for industrial food, pharmaceuticals, nutraceuticals, and agricultural applications. 
Antioxidants can also be delivered to the body in the form of dietary supplements. The synthetic forms of antioxidants are bioequivalent to their natural forms, e.g., biovitamin $\mathrm{C}$ vs. chemically synthesized L-ascorbic acid, or synthetic and natural R, R, R- $\alpha$-tocopherol. Antioxidants are also used as additives to prevent the oxidation of unstable ingredients in the food, cosmetic, and pharmaceutical industries. This mainly concerns synthetic antioxidants with a phenolic structure, such as butylated hydroanisole (BHA), butylated hydrotoluene (BHT), and tert-butylated hydroquinone (TBHQ), which are added to foodstuffs to prevent lipid rancidity [80].

Antioxidants differ in their ability to scavenge free radicals. It has been shown that antioxidant activity can be significantly correlated with the number of active groups such as $\mathrm{OH}$ or $\mathrm{NH}_{2}$ and the position of these functional groups in the order ortho > para > meta, from the highest to the lowest active [81]. It should be remembered that antioxidants can act through various mechanisms, not only scavenging radicals, but also sequestering transition metal ions, decomposing hydrogen peroxide or hydroperoxides, quenching active pro-oxidants, and enhancing endogenous antioxidant defense but also by repairing the resulting cellular damage. Therefore, antioxidants are sometimes classified as primary or chain-breaking antioxidants and as secondary or preventive antioxidants [82]. Primary antioxidants actively inhibit oxidation reactions by scavenging ROS/RNS, while secondary antioxidants act indirectly through chelation of transition metal (iron) ions [83,84] and other specific actions such as anti-inflammatory, induction of protective factors, inhibition of NADPH oxidase (nicotinamide adenine dinucleotide phosphate oxidase), inhibition of xanthine oxidase, and regulation of redox-sensitive signal transduction pathways, including transcription factors and inhibition of poly (ADP-ribose) -1 (PARP-1) polymerase $[81,85,86]$. Another indirect way of antioxidant activity is the activation of transcription factors, including Nrf2, which in turn leads to the activation of endogenous antioxidant enzymes [87].

Currently, the role of exogenous antioxidants in preventing or delaying oxidative damage is becoming more and more controversial. The initial enthusiasm for their positive health effects was mainly based on in vitro experiments. In the initial studies, the in vivo bioavailability of the antioxidants, which is generally quite low, was neglected. In this context, the activity of scavenging free radicals by antioxidant metabolites seems to be more reliable $[50,88]$. The high in vitro chemical reactivity of the antioxidant is therefore not evidence of its effectiveness in vivo. Moreover, as shown by individual studies $[89,90]$, supplementation with antioxidants may be ineffective and even very dangerous. An example may be the disappointing research on the effectiveness of vitamin $E$ in the risk of cardiovascular disease or hemorrhagic stroke [91-95]. Reports that the use of antioxidants not only prevent cancer but may also provoke it are also alarming [96]. As it turns out, it is especially dangerous to supplement with antioxidants in doses exceeding the daily intake. For example, supplementation with $\beta$-carotene over ten times the daily intake increased the incidence of lung cancer in smoking men by $18 \%$ [97]. Vitamin C supplementation is particularly controversial. Linus Pauling recommended health-promoting use of a high daily dose of $1000 \mathrm{mg}$ [98]. Unfortunately, it turned out that even at low concentrations of ascorbic acid, a pro-oxidative effect can occur in the presence of transition metals, e.g., iron. An example of this effect is the effect of ascorbic acid on iron-induced lipid peroxidation [99].

In the review by Hrelia and Angeloni [100], recent reports on new mechanisms of action of natural antioxidants are collected. Their study highlights the fact that natural antioxidants are heavily metabolized in vivo, a result of which is that their redox potential drops significantly at the physiological level.

The authors observed a growing interest in the scientific community in the interactions of natural antioxidants with proteins that are involved in intracellular signaling cascades and modulation of the gut microflora.

Currently, in research on natural antioxidants, research issues can be distinguished regarding (i) combination therapies using the synergistic effect of natural antioxidants, (ii) 
anti-aging effects of fermented preparations, (iii) enzyme research, (iv) genetic research, (v) studies on the effect of antioxidants on the intestinal microflora, and (vi) the effect of antioxidants on hormonal activity.

\section{Antioxidant Capacity/Activity Measurements}

Determination of antioxidant status attracts growing attention for clinical purposes [48,101] However, the determination of antioxidative potential, in this case, is difficult to establish due to the complex mechanisms of action for the individual anti-oxidants. Some of them act by scavenging free radicals, some by preventing the formation of ROS or inducing the signaling pathways or by repairing the oxidative damage. Cellular protection is ensured mainly by enzymes (glutathione peroxidase, SOD, catalase), whereas the nonenzymatic antioxidants act in the plasma. Additionally, the status of redox homeostasis differs significantly between the individuals; therefore, the reference values have not been established so far [102,103]. Presently, there is also no direct method dedicated to accurate measurement of oxidative stress in vivo conditions. Therefore, oxidative stress is measured by the use of multiple in vitro assays [102], which can identify free radicals directly like electron paramagnetic resonance (EPR) or electron spin resonance (ESR) spectroscopy, fluorescent probes, or indirect methods enabled to identify the stable products which are created as a consequence of the free radical attack, like chromatography, colorimetry, and immune, or enzymatic tests [104].

There is also some misunderstanding regarding specific terms that are used to describe antioxidants measurement assays. Bunaciu et al., in a critical review [105], pointed out that the terms "antioxidant activity" and "antioxidant capacity" need some more clarification because they are often used interchangeably despite having different meanings. It should be emphasized that the term "antioxidant activity" refers to kinetic-based assays measuring the rate constant of a reaction between reactants or scavenging percentages per unit time. Thus, the term is characteristic of a specific antioxidant and oxidant, expressed as reaction rates value. In turn, the antioxidant capacity can be defined as the efficiency of antioxidants to inhibit the oxidative degradation of the various bio-compounds. The measurements are based on the reaction between studied antioxidants and free radicals (reactive species inactivation, quenching, or scavenging) or on the reaction of the sample with transition metals. Antioxidant capacity expresses the amount (in moles) of a given free radical that is scavenged by a sample.

In the case of a heterogeneous mixture, the antioxidant capacity of each individual component is not possible to measure as all antioxidants react simultaneously to produce the total scavenging ability of the sample. In the case of the complex samples, the most reasonable way of their antioxidant capacity is using a variety of methods that can address the different mechanisms of action of individual components [106,107]. The collaborative effect of all sample components (i.e., synergistic or antagonistic effects) is responsible for "total antioxidant capacity" (TAC) measured.

Antioxidants' capacity can be estimated by considering the final effects of their presence, by the use of in vitro tests, or directly by more complex methods utilizing exogenic probes to detect oxidation. With such a variety of mechanisms involved in the action of antioxidants, determining the level of total antioxidant capacity (TAC) is one of the major challenges in antioxidant testing. Thus far, no universal method has been developed that would gain general and univocal acceptance. Therefore, when choosing a specific method, one should be aware of what kind of an antioxidant function is being measured [46,108].

The measured activity of primary antioxidants reflects their ability to scavenge ROS/RNS throughout hydrogen atom $\left(\mathrm{H}^{\bullet}\right)$ or electron $\left(\mathrm{e}^{-}\right)$transfer or both species simultaneously (i.e., proton-coupled electron transfer). Secondary antioxidants, which are known as preventive ones, are evaluated by the chelating ability of selected transition metal ions e.g., $\mathrm{Fe}(\mathrm{II})$ or $\mathrm{Cu}(\mathrm{I})$. Preventive antioxidants act by inhibiting Fenton reactions as a source of hydroxyl radicals or a Lewis acid-base neutralization (metal ion-antioxidant). In turn, endogenous antioxidative enzymes, being "first-line defense antioxidants" such as 
SOD, CAT, and GPx, which are able to scavenge superoxide anion radicals and hydrogen peroxides, require enzymatic methods for evaluation of the antioxidants activity [108].

Nonenzymatic primary antioxidant assays can be non-competitive or competitive [109]. Competitive assays such as TRAP, ORAC, TOSC, crocin bleaching, peroxyl radical trapping antioxidant parameter, act due to the competition between a fluorogenic or chromogenic probe and antioxidants for the reactive species (ROS/RNS). In the presence of antioxidants, the probe undergoes weaker oxidation, which is reflected in the changes of its measurable properties (absorbance, fluorescence, luminescence) [110] (Figure 2).

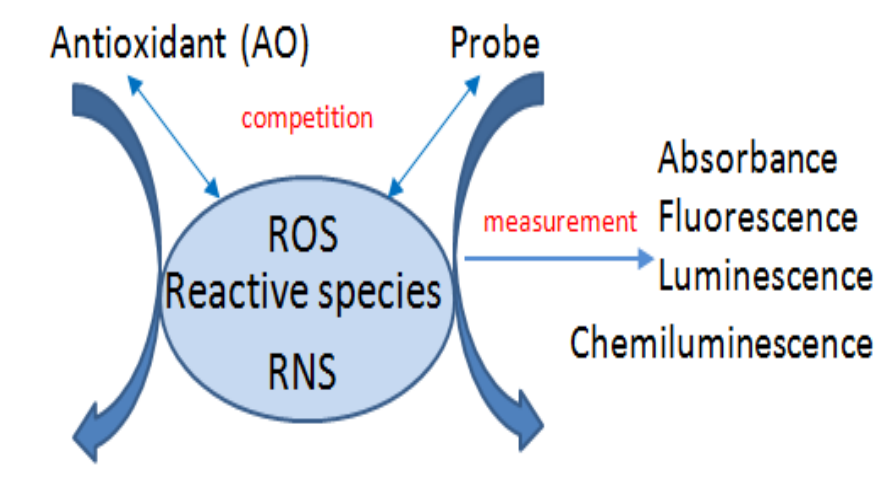

\section{Oxidized AO Oxidized probe}

Figure 2. Schematic illustration of competitive antioxidant (AO) assay.

The non-competitive (Figure 3) ones based on Folin-Ciocalteu reaction, ABTS/TEAC, CUPRAC, FRAP, DPPH, ABTS differ in the lack of the presence of any competing target molecule. TAC measurements are considered to be noncompetitive if they rely on electron transfer (ET) mechanism, whereas competitive measurements are usually based on a hydrogen atom transfer (HAT) [46].

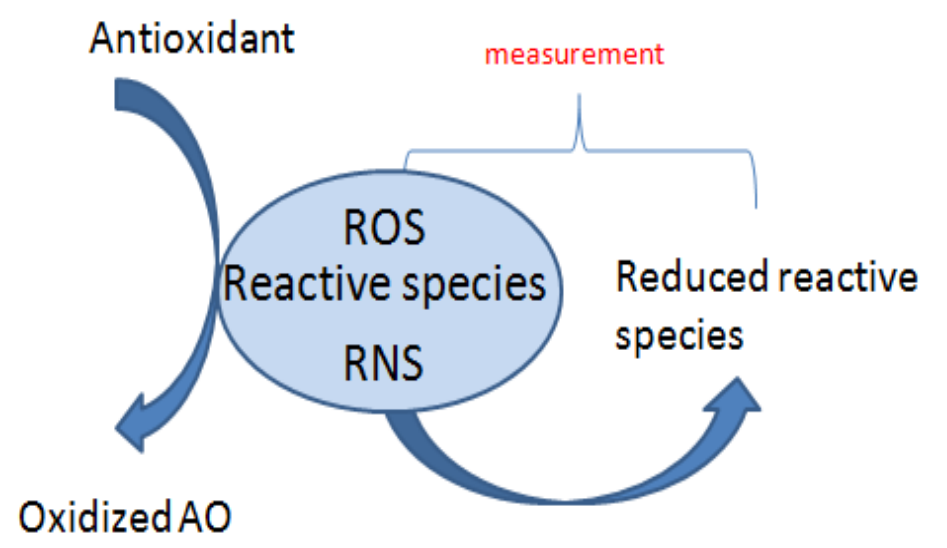

Figure 3. Schematic representation of non-competitive antioxidant (AO) assay.

In certain circumstances, ET/HAT mechanisms may not be easily identified like for 2,2'azinobis-(3-ethylbenzothiazoline-6-sulfonic acid (ABTS), and 2,2-diphenyl-1-picrylhydrazyl (DPPH) assays, which are sometimes classified as mixed-mode assays (ET/HAT). Both free radicals react according to two mechanisms: HAT (1) and SET (single electron transfer) (2):

$$
\text { HAT: } \mathrm{DPPH}^{\bullet}+\mathrm{A} \rightarrow \mathrm{DPPH}-\mathrm{H}+\mathrm{A}^{\bullet},
$$

SET: $\mathrm{DPPH}^{\bullet}+\mathrm{AH} \rightarrow \mathrm{DPPH}^{-}+\mathrm{AH}^{+\bullet} ; \mathrm{AH}^{+\bullet} \rightarrow \mathrm{AH}^{\bullet}+\mathrm{H}^{+} ; \mathrm{DPPH}^{-}+\mathrm{H}^{+} \rightarrow \mathrm{DPPH}-\mathrm{H}$, 
Experimental investigations [111,112] confirm that HAT and SET transformations may occur at the same time as a sequential proton-loss electron transfer (SPLET), which is also named as a proton-coupled electron transfer (PCET) [106]:

SPLET: $\mathrm{AH} \rightarrow \mathrm{AH}^{-}+\mathrm{H}^{+} ; \mathrm{AH}^{-}+\mathrm{DPPH}^{\bullet} \rightarrow \mathrm{AH}^{\bullet}+\mathrm{DPPH}^{-} ; \mathrm{DPPH}^{-}+\mathrm{H}^{+} \rightarrow$ DPPH-H

It has been proven that the HAT mechanism dominates in aqueous solutions. In turn, the SET and SPLET may dominate in non-aqueous solutions due to the possibility of organic solvents forming hydrogen bonds with molecules of antioxidants [113-116]. Among the SET methods, the most used are DPPH radical scavenging capacity assay, Trolox equivalent antioxidant capacity (TEAC or ABTS) assay, ferric reducing (FRAP) assay, reducing power assay (RP), and copper reduction (CUPRAC) assay. HAT assays include the total per-oxyl radical-trapping antioxidant parameter (TRAP) assay, the crocin bleaching assay, oxygen radical absorbance capacity (ORAC) assay, and total oxyradical scavenging capacity (TOSC) assay.

Antioxidant activity can also be estimated using nanoparticle-based assays utilizing nanoparticles probes exhibiting localized surface Plasmon resonance (LSPR) absorption $[117,118]$. It has been established that the LSPR absorption connected with the nanoparticles grove rises linearly depending on antioxidant concentration. Scampicchio et al. described such correlation for gold nanoparticles (AuNPs) generated under the influence of phenolic acid antioxidants being able to donate electrons. Özyürek et al. proved the same for silver nanoparticles (Ag-NPs), which were formed as a product of $\mathrm{AgNO}_{3}$ reduction with polyphenolic antioxidants.

Many studies are dedicated to the estimation of the antioxidant power of various individual chemicals, as well as food samples and natural extracts [119]. For this purpose, various tests were applied, including, among others, the oxygen radical absorbance capacity test, the Trolox equivalent antioxidant capacity, and the ability to reduce metal ions, such as copper or iron. Several reviews have been published that highlight the advantages and disadvantages of the available tests [120-124]. However, there is still no standard quantitative method for measuring antioxidant activity. Therefore, it is extremely difficult to compare the results obtained from different studies. The complexity and variety of research systems make it impossible to repeat and confirm experiments by independent laboratories. The most common methods related to the antioxidant assessment are summarized in Table 2.

Table 2. Examples of the non-enzymatic assays used for in vitro determination of antioxidant capacity with distinguished chromogenic agents, observed changes, the principle, mode, and mechanism of the assay (Mech).

\begin{tabular}{|c|c|c|c|c|c|c|}
\hline Assay & $\begin{array}{c}\text { The } \\
\text { Chromogenic Agents }\end{array}$ & Observed Changes & Principle of Assay & Mode & Mech & Ref \\
\hline \multicolumn{7}{|c|}{ Total antioxidant capacities } \\
\hline Crocin bleaching & crocin & bleaching of crocin & $\begin{array}{l}\text { The ability of AOs to inhibit } \\
\text { oxidation of crocin. }\end{array}$ & $\begin{array}{l}\text { Abs. } \\
443 \mathrm{~nm} \\
\mathrm{pH}=7.0-7.5\end{array}$ & HAT & {$[125,126]$} \\
\hline $\begin{array}{l}\text { ORAC } \\
\text { (Oxygen radical } \\
\text { absorbance capacity) }\end{array}$ & $\begin{array}{l}\text { fluorescein, } \\
\text { dichloro- fluorescein }\end{array}$ & fluorescence decay & $\begin{array}{l}\text { The fluorescence caused by } \\
\text { oxidation of the probe by } \\
\text { peroxyl-radical initiated by thermal } \\
\text { decomposition of AAPH, is } \\
\text { delayed/inhibited by AOs. }\end{array}$ & $\begin{array}{l}\text { Fl. } \\
\lambda_{\mathrm{ex}}=485 \mathrm{~nm} \\
\lambda_{\mathrm{em}}=538 \mathrm{~nm} \\
\mathrm{pH}=7.4\end{array}$ & HAT & [127] \\
\hline $\begin{array}{l}\text { TRAP (Total peroxyl } \\
\text { radical trapping } \\
\text { antioxidant parameter) }\end{array}$ & $\beta$-phycoerythrin & fluorescence decay & $\begin{array}{l}\text { Fluorescence decay along time due } \\
\text { to oxidation of the probe is delayed } \\
\text { by AOs. }\end{array}$ & $\begin{array}{l}\text { Fl. } \\
\lambda_{\text {ex }}=495 \mathrm{~nm} \\
\lambda_{\text {em }}=575 \mathrm{~nm} \\
\mathrm{pH}=7.5\end{array}$ & HAT & {$[128,129]$} \\
\hline$\beta$-carotene bleaching assay & $\beta$-carotene & $\begin{array}{l}\text { bleaching yellow color } \\
\text { of } \beta \text {-carotene }\end{array}$ & $\begin{array}{l}\text { The ability of AOs to slow down the } \\
\text { rate of } \beta \text {-carotene bleaching due to } \\
\text { its reaction with peroxyl radicals, } \\
\text { which are formed by linolenic } \\
\text { acid oxidation. }\end{array}$ & $\begin{array}{l}\text { Abs. } \\
470 \text { nm } \\
\text { pH }=5.5-7.5\end{array}$ & HAT & {$[130,131]$} \\
\hline $\begin{array}{l}\text { PCL } \\
\text { (Photochemiluminescence) }\end{array}$ & luminol & blue light emision & $\begin{array}{l}\text { An AO-sensitive inhibition of a } \\
\text { photo-induced, chemiluminescence } \\
\text { accompanying autooxidation of } \\
\text { luminol. }\end{array}$ & $\begin{array}{l}\mathrm{Cl} . \\
360 \mathrm{~nm} \\
\mathrm{pH}=10.5\end{array}$ & HAT & [132-134] \\
\hline
\end{tabular}


Table 2. Cont.

\begin{tabular}{|c|c|c|c|c|c|c|}
\hline Assay & $\begin{array}{c}\text { The } \\
\text { Chromogenic Agents }\end{array}$ & Observed Changes & Principle of Assay & Mode & Mech & Ref \\
\hline \multicolumn{7}{|c|}{ Reducing antioxidant power (RP) } \\
\hline $\begin{array}{l}\text { FRAP } \\
\text { (Ferric reducing } \\
\text { antioxidant potential) }\end{array}$ & $\begin{array}{l}\text { ferric tripyridyl } \\
\text { triazine }\end{array}$ & yellow color to blue & $\begin{array}{l}\text { AOs as reductant at low } \mathrm{pH} \text { can } \\
\text { reduce ferric tripyridyl triazine to } \\
\text { ferrous form, causing } \\
\text { absorbance ncrease. }\end{array}$ & $\begin{array}{l}\text { Abs. } \\
593 \mathrm{~nm} \\
\mathrm{pH}=3.6\end{array}$ & ET & [135] \\
\hline $\begin{array}{l}\text { CUPRAC } \\
\text { (cupric ion } \\
\text { reducing } \\
\text { antioxidant capacity) }\end{array}$ & $\mathrm{Cu}(\mathrm{II})$ complex & $\begin{array}{l}\text { light blue to } \\
\text { orange-yellow }\end{array}$ & $\begin{array}{l}\text { Ability of AO for the reduction of } \\
\mathrm{Cu}(\mathrm{II}) \text { in } \\
\text { bathocuproine(2,9-dimethyl-4,7- } \\
\text { diphenyl-1,10-phenanthroline) or } \\
\text { neocuproine } \\
\text { (2,9-dimethyl-1,10-phenanthroline) } \\
\text { complexes to } \mathrm{Cu}(\mathrm{I}) \text { forms. }\end{array}$ & $\begin{array}{l}\text { Abs. } \\
490 \mathrm{~nm} 450 \mathrm{~nm} \\
\mathrm{pH}=7\end{array}$ & ET & [136] \\
\hline $\begin{array}{l}\text { CERAC } \\
\text { (Ce(IV)-based } \\
\text { reducing capacity) }\end{array}$ & $\mathrm{Ce}(\mathrm{IV})$ & fluorescence & $\begin{array}{l}\text { The ability of AO to reduce Ce(IV) } \\
\text { to Ce(III) accopanied with } \\
\text { fluorescence elevation. }\end{array}$ & $\begin{array}{l}\text { Fl. } \\
\lambda_{\mathrm{ex}}=256 \mathrm{~nm} \\
\lambda_{\mathrm{em}}=360 \mathrm{~nm} \\
\mathrm{pH} \text { acidic }\end{array}$ & ET & {$[137,138]$} \\
\hline $\begin{array}{l}\text { CHROMAC (Chromium } \\
\text { reducing } \\
\text { antioxidant capacity) }\end{array}$ & $\mathrm{Cr}$ (VI) with DPC & red-violet product & $\begin{array}{l}\text { The reduction of chromate(VI) to } \\
\mathrm{Cr}(\mathrm{III}) \text { in acidic solution. The } \\
\text { remaining Cr(VI) reacts with DPC to } \\
\text { produce a chelate complex. The } \\
\mathrm{Cr}(\mathrm{VI}) \text { consumption was correlated } \\
\text { with } \mathrm{AO}^{\prime} \text { concentration. }\end{array}$ & $\begin{array}{l}\text { Abs. } \\
540 \mathrm{~nm} . \\
\mathrm{pH}=2.8\end{array}$ & ET & [139] \\
\hline $\begin{array}{l}\text { Phosphomolybdenum } \\
\text { assay }\end{array}$ & $\begin{array}{l}\text { Phosphormolybdenum } \\
\text { complex }\end{array}$ & green product & $\begin{array}{l}\text { The reduction of } \mathrm{Mo}(\mathrm{Vl}) \text { to } \mathrm{Mo}(\mathrm{V}) \\
\text { by } \mathrm{AO} \text {. }\end{array}$ & $\begin{array}{l}\text { Abs. } 695 \mathrm{~nm} \\
\text { pH acidic }\end{array}$ & ET & [140] \\
\hline $\begin{array}{l}\text { The Folin-Ciocalteu } \\
\text { (FC) assay }\end{array}$ & $\begin{array}{l}\text { Tungstate-molybdate } \\
\text { complexes }\end{array}$ & from yellow to dark blue & $\begin{array}{l}\text { FC reagent in a basic medium is able } \\
\text { to oxidize reducing substances, } \\
\text { mainly phenolic and polyphenolic } \\
\text { AOs. The change in color is } \\
\text { connected with transformation of } \\
\text { Mo(VI) to Mo(V), causing } \\
\text { absorbance increase. }\end{array}$ & $\begin{array}{l}\text { Abs. } \\
750-765 \mathrm{~nm} \mathrm{pH} \\
=10\end{array}$ & ET & [109] \\
\hline $\begin{array}{l}\text { PFRAP } \\
\text { (Potassium ferricyanide } \\
\text { reducing power assay) }\end{array}$ & $\begin{array}{l}\text { Ferricyanide reagent: } \\
\mathrm{Fe}(\mathrm{III}), \mathrm{Fe}(\mathrm{CN})_{6}{ }^{3-}\end{array}$ & prussian blue & $\begin{array}{l}\text { The AOs react with potassium } \\
\text { ferricyanide } \mathrm{Fe}(\mathrm{CN})_{6}{ }^{3-} \text { ) forming } \\
\text { potassium ferrocyanide } \mathrm{Fe}(\mathrm{CN})_{6}{ }^{4-} \\
\text { which further reacts with } \mathrm{FeCl}{ }_{3} \text { to } \\
\text { form prussian blue } \mathrm{KFe}\left[\mathrm{Fe}(\mathrm{CN})_{6}\right]\end{array}$ & $\begin{array}{l}\text { Abs. } \\
700 \mathrm{~nm} \\
\mathrm{pH}=6.6\end{array}$ & ET & [141] \\
\hline $\begin{array}{l}\text { FTC } \\
\text { (Ferric thiocyanate) }\end{array}$ & $\mathrm{Fe}(\mathrm{S}-\mathrm{CN})_{2}$ & red color & $\begin{array}{l}\text { A hydroperoxide formed from a } \\
\text { lipid (linoleic acid) oxidizes a } \\
\text { ferrous ion to a ferric ion. The AO } \\
\text { causes an inhibitory effect on } \\
\text { hydroperoxide formation or by its } \\
\text { ability to donate an electron to } \\
\text { ferric ion. }\end{array}$ & $\begin{array}{l}\text { Abs. } \\
500 \mathrm{~nm}\end{array}$ & ET & {$[142,143]$} \\
\hline $\begin{array}{l}\text { FOX (Ferrous } \\
\text { Oxidation-Xylenol } \\
\text { Orange Assay) }\end{array}$ & $\begin{array}{l}\text { ferric-XO } \\
\text { complex }\end{array}$ & blue-purple color & $\begin{array}{l}\text { The presence of hydroperoxides that } \\
\text { oxidize ferrous ion to ferric ion, } \\
\text { which subsequently react with } \\
\text { xylenol orange }(\mathrm{XO}) \text {. }\end{array}$ & $\begin{array}{l}\text { Abs. } \\
550 \mathrm{~nm} \text {. }\end{array}$ & ET & [144] \\
\hline \multicolumn{7}{|c|}{ Assays associated with lipid peroxidations } \\
\hline $\begin{array}{l}\text { LPO } \\
\text { (Lipid peroxidation } \\
\text { inhibition assay) }\end{array}$ & $\begin{array}{l}\text { N-methyl-2- } \\
\text { phenylindole }\end{array}$ & dye product & $\begin{array}{l}\text { AOs delay radical-induced malonyl } \\
\text { dialdehyde generation. MDA and } \\
\text { HAE are measured as an indicator } \\
\text { of lipid peroxidation. The product } \\
\text {-MDA with chromogenic reagent } \\
\text { gives carbocyanine adduct. }\end{array}$ & $\begin{array}{l}\text { Abs. } \\
586 \mathrm{~nm}\end{array}$ & ET & {$[138,145]$} \\
\hline $\begin{array}{l}\text { TBARS (Thiobarbituric } \\
\text { acid reactive } \\
\text { substances assay) }\end{array}$ & TBARS & red-pink color & $\begin{array}{l}\text { The reaction of lipid peroxidation } \\
\text { products (MDA), with TBA, leads to } \\
\text { the formation of MDA-TBA } \\
\text { adducts (TBARS). }\end{array}$ & $\begin{array}{l}\text { Abs. } \\
532 \mathrm{~nm} \\
\mathrm{pH}=4\end{array}$ & ET & $\begin{array}{l}{[130,131,} \\
146,147]\end{array}$ \\
\hline Conjugated diene assay & linoleic acid & UV absorbance & $\begin{array}{l}\text { Antioxidants delay conjugated } \\
\text { dienes formation. The AO effect can } \\
\text { be evaluated by monitoring the } \\
\text { conjugated diene formation. }\end{array}$ & $\begin{array}{l}\text { Abs. } \\
234 \mathrm{~nm}\end{array}$ & & [148] \\
\hline \multicolumn{7}{|c|}{ Radical scavenging assays } \\
\hline DPPH & $\begin{array}{l}\text { 2,2-diphenyl-1- } \\
\text { picrylhydrazyl } \\
\text { radical }\end{array}$ & $\begin{array}{l}\text { deep violet to pale } \\
\text { yellow or colorless }\end{array}$ & $\begin{array}{l}\text { The decrease in DPPH absorbance } \\
\text { depends linearly on } \\
\text { AO' concentration. }^{\prime} \text { ' }\end{array}$ & $\begin{array}{l}\text { Abs. } \\
515-517 \mathrm{~nm} \\
\mathrm{pH}=7\end{array}$ & $\mathrm{HAT} / \mathrm{ET}$ & Г $[130]$ \\
\hline ABTS & $\begin{array}{l}\text { 2,2'-azino-bis(3- } \\
\text { ethylbenzothiazoline- } \\
\text { 6-sulfonic } \\
\text { acid }\left(\mathrm{ABTS}^{+\cdot}\right)\end{array}$ & bluish-green to colorless & 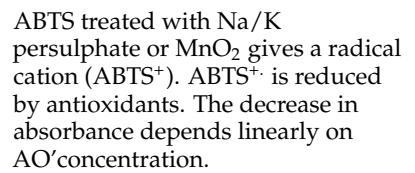 & $\begin{array}{l}\text { Abs. } \\
734 \mathrm{~nm} \\
\mathrm{pH}=7.4\end{array}$ & $\mathrm{HAT} / \mathrm{ET}$ & Г [149] \\
\hline
\end{tabular}


Table 2. Cont.

\begin{tabular}{|c|c|c|c|c|c|c|}
\hline Assay & $\begin{array}{c}\text { The } \\
\text { Chromogenic Agents }\end{array}$ & Observed Changes & Principle of Assay & Mode & Mech & Ref \\
\hline $\begin{array}{l}\text { DMPD } \\
\text { (N,N-dimethyl-p- } \\
\text { phenylene-diamine) }\end{array}$ & $\mathrm{DMPD}^{++}$radical cation & reduction of purple color & $\begin{array}{l}\text { DMPD }{ }^{+} \text {is generated through a } \\
\text { reaction between DMPD and } \\
\text { potassium persulphate the assay } \\
\text { measures scavenging of free radicals } \\
\text { by AOs. }\end{array}$ & $\begin{array}{l}\text { Abs. } \\
517 \mathrm{~nm} \\
\mathrm{pH}=5.25\end{array}$ & HAT & {$[150,151]$} \\
\hline $\begin{array}{l}\text { SOSA (Superoxide Anion } \\
\text { Radical } \\
\text { Scavenging Capacity) }\end{array}$ & NBT & yellow to blue & $\begin{array}{l}\text { The ability of the AO to compete } \\
\text { with NBT to scavenge } \mathrm{O}_{2}^{\bullet-} \\
\text { generated by an enzymatic } \\
\text { HPX-XOD, X-XOD or } \\
\text { PMS/NADH systems. }\end{array}$ & $\begin{array}{l}\text { Abs. } \\
560 \mathrm{~nm} \\
\mathrm{pH}=7.4\end{array}$ & ET & {$[135,152]$} \\
\hline $\begin{array}{l}\text { Nitric oxide free radical } \\
\text { scavenging activity }\end{array}$ & Griess reagent & $\begin{array}{l}\text { colorless to light pink to } \\
\text { deep purple }\end{array}$ & $\begin{array}{l}\text { NO was generated from sodium } \\
\text { nitroprusside and measured by the } \\
\text { Greiss reaction. AO reduces the } \\
\text { amount of nitrite. }\end{array}$ & $\begin{array}{l}\text { Abs. } \\
546 \mathrm{~nm} \\
\mathrm{pH}=7.4\end{array}$ & ET & [153] \\
\hline $\begin{array}{l}\text { Peroxynitrite Scavenging } \\
\text { Capacity Assay }\end{array}$ & Evans Blue & dye bleaching & $\begin{array}{l}\text { The percentage of scavenging of } \\
\text { ONOO }^{-} \text {by the Evans Blue was } \\
\text { measured in presence of AO. }\end{array}$ & $\begin{array}{l}\text { Abs. } \\
611 \mathrm{~nm} \\
\mathrm{pH}<7\end{array}$ & ET & [154] \\
\hline
\end{tabular}

$\mathrm{OH}$ radicals are generated by a

Co(II)-mediated Fenton-like reaction.

The reaction is confirmed by the

hydroxylation of p-hydroxybenzoic

HORAC (Hydroxyl

Radical Averting

Capacity Assay) fluorescein fluorescence decay

acid. Metal ion-induced $\mathrm{OH}$ radical

generation reaction can be

Fl.

monitored by the fluorescence decay

of fluorescein. In the presence of $\mathrm{AO}$

the formation of $\mathrm{OH}$ radicals can be

inhibited because the metal is

deactivated due to coordination

with $\mathrm{AO}$

A mixture of $\mathrm{Fe}(\mathrm{III})$-EDTA, $\mathrm{H}_{2} \mathrm{O}_{2}$

vit. $\mathrm{C}$ generates $\mathrm{OH}$ radical, is able to

degrade deo

The products

heated under acidic conditions form

MDA detected by adduct with TBA.

AO can inhibit deoxyribose damage.

The Fenton system generates a

constant flux of pure $\mathrm{OH}$ radicals.

ESR measurements evaluate the $\mathrm{OH}$

radicals scavenging capacity of AOs.

Scavenging Capacity

Fenton-like system

Assay

$\mathrm{Fe}(\mathrm{II})^{/} \mathrm{H}_{2} \mathrm{O}_{2}$

The ability of AOs to prevent

oxidation of DCFH by azide

generated peroxyl radicals in human

hepatocarcinoma HepG2 cells.

fluorescence

Activity Assays)

DCFH-DA

decay

Nonradical reactive oxygen species scavenging assay

Hydroxyl radicals are the

byproducts of $\mathrm{H}_{2} \mathrm{O}_{2}$ decomposition.

They initiate lipid peroxidation.

After the addition of AO, the

absorbance is measured against

$\lambda_{\text {ex }}=493$

$\lambda_{\mathrm{em}}=515 \mathrm{~nm}$

HAT [130,135,

blank (phosphate buffer).

Production of singlet oxygen $\left(1 \mathrm{O}_{2}\right.$ was achieved by monitoring RNO

bleaching. Singlet oxygen was generated by a reaction between $\mathrm{NaOCl}$ and $\mathrm{H}_{2} \mathrm{O}_{2}$.

Abs.

$532 \mathrm{~nm}$

ET

$\mathrm{pH}=7.4$

Electron spin

resonance ET

ET [157]

(ESR)

$\lambda_{\text {exc. }} 502 \mathrm{~nm}, \quad$ ET

[158]

$\lambda_{\mathrm{em}} 520 \mathrm{~nm}$

The stoichiometric conversion from

alkylaldehyde (hexanal) to

alkylcarboxylic acid in the presence

of radicals induced by heat, $\mathrm{O}_{2}$,

GC

ET

(Aldehyde/carboxylic alkylcarboxylic acid $\mathrm{H}_{2} \mathrm{O}_{2}$

$230 \mathrm{~m}$

$\mathrm{pH}=7.4$

ET

Metal chelating capacity assays (MCA)

The capacity to chelate ferrous ion can be disturbed by the presence of other complexing agents (AOs),

Abs.

which cause a decrease intensity of the complex (Fe(II) and ferrozine).

chelating assay

Fe(II) with

ferrozine

blue

The chelating activity can be

estimated by the measurement of

$\mathrm{pH}=4-10$

Copper(II) chelating

capacity assay

$\mathrm{Cu}(\mathrm{II})-\mathrm{PV}$

dark to

yellow

\section{Abs.}

$632 \mathrm{~nm}$

$\mathrm{pH}=6$
ET

[163] 
Table 2. Cont.

\begin{tabular}{|c|c|c|c|c|c|c|}
\hline Assay & $\begin{array}{c}\text { The } \\
\text { Chromogenic Agents }\end{array}$ & Observed Changes & Principle of Assay & Mode & Mech & Ref \\
\hline \multicolumn{7}{|c|}{ Nanoparticles (NPs)-based assays } \\
\hline $\begin{array}{l}\text { Gold nanoparticles } \\
\text { (Au-NPs) }\end{array}$ & NPs & $\begin{array}{l}\text { No color into } \\
\text { dark red }\end{array}$ & $\begin{array}{l}\text { The highest capacity of reducing } \\
\text { gold(III) to gold NPs corresponds to } \\
\text { the highest antioxidant activity. } \\
\text { Alternatively, cyclic voltammetry } \\
\text { measures anodic peak potentials }\end{array}$ & $\begin{array}{l}\text { Abs. } \\
555 \mathrm{~nm} \\
\mathrm{pH}=8\end{array}$ & ET & {$[117,118]$} \\
\hline $\begin{array}{l}\text { Silver nanoparticles } \\
\text { (Ag-NPs) }\end{array}$ & NPs & no color into pale yellow & $\begin{array}{l}\text { Nanoparticles generated from metal } \\
\text { salts upon reduction with } \\
\text { antioxidants in the presence of } \\
\text { citrate-stabilized silver seeds. }\end{array}$ & $\begin{array}{l}\text { Abs. } \\
423 \mathrm{~nm} \\
\mathrm{pH}=7\end{array}$ & ET & [118] \\
\hline
\end{tabular}

Abbreviations: AAPH (2,2'-azobis-2-methyl-propanimidamide,dihydrochloride); Abs. (Absorbance); DPC (1,5-diphenylcarbazide); XO (xylenol orange); MDA (malondialdehyde); HAE (4-hydroxyalkenals); NBT (nitroblue tetrazolium); Griess reagent (1\% sulfanilamide, $2 \%$ $\mathrm{H}_{3} \mathrm{PO}_{4}$, and $0.1 \%$ naphthylethylenediamine dihydrochloride); DCFH (dichlorofluorescein); Luminol (5-amino-2,3-dihydrophthalazine1,4-dione); Cl. (Chemiluminescence), Abs. (Absorbance); Fl. (Fluorescence); HPX-XOD (hypoxanthine-xanthine oxidase); X-XOD (xanthine-xanthine oxidase); PMS/NADH (phenazine methosulphate systems); AO (antioxidant); PV (pyrocatechol violet); RNO (N, Ndimethyl-p-nitrosoaniline); DCFH-DA (2',7'-dichloro-dihydrofluorescein diacetate); triazine (2,3,5- triphenyl-1,3,4-triaza-azoniacyclopenta1,4-diene chloride).

\subsection{Techniques Used to Assess Antioxidant Capacity}

A number of techniques are used to assess antioxidant capacities, such as UV-Vis spectroscopy, fluorescence spectroscopy, chemiluminescence, electron paramagnetic resonance (EPR), enzyme-catalyzed assays [164-168], and cell culture assays. Moreover, there are some electrochemical techniques, including controlled potential techniques, electrochemical sensors, and biosensors, which are commonly applied [169]. However, the most widely used techniques for evaluating the ability of an antioxidant to scavenge e.g., $\mathrm{ABTS}^{\bullet+}$, $\mathrm{DPPH}^{\bullet}, \mathrm{O}_{2}{ }^{\bullet-}, \mathrm{H}_{2} \mathrm{O}_{2}$, a total antioxidant reducing capacity, e.g., TEAC, ORAC, and FRAP belong to spectrometric techniques. These methods have been commonly used to determine the antioxidant capacity of many plant extracts, foods, and dietary supplements [170-174]. These assays despite some drawbacks [129] are easy to use.

\subsubsection{DPPH Free Radical Scavenging Assay}

To measure antioxidants' power, their ability to deactivate free radicals was used. One of the most frequently used stable free radicals is DPPH (1,1-diphenyl-2-picrylhydrazyl) discovered by Goldsmith and Renn in 1922 [175]. Due to the relocation of the unpaired electron, DPPH forms a stable radical cation and does not form dimers in alcohol solutions $[176,177]$. The DPPH solution has a dark purple color with maximum absorbance at wavelength $=517 \mathrm{~nm}$. By reaction with a substance that gives off a hydrogen atom, a reduced form of DPPH 2,2-diphenyl-1-picrylhydrazine is formed, and then the purple color of the solution changes to yellow with a concomitant decrease in absorbance (Figure 4).

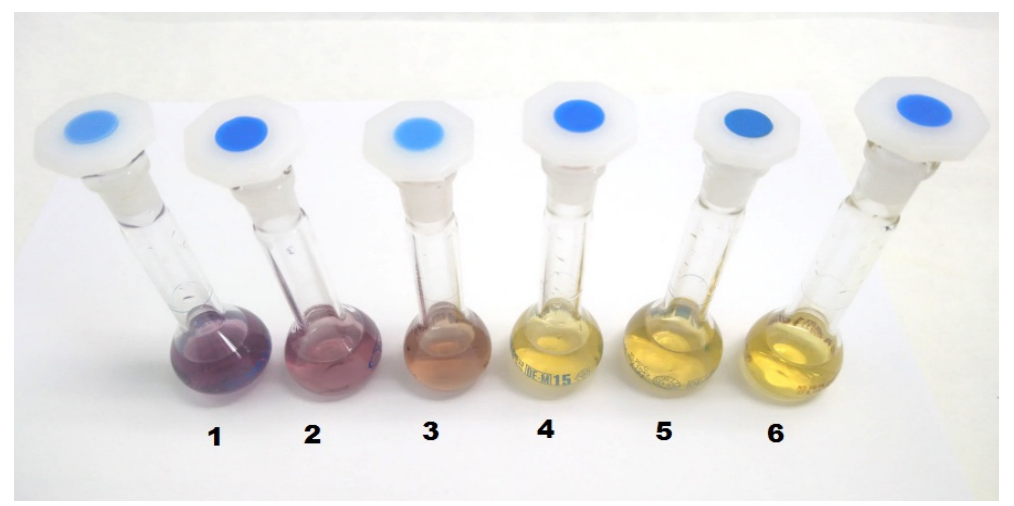

Figure 4. $1 \mathrm{mM}$ DPPH solutions containing an increasing amount of Salvia officinalis extract: $1-20 \mu \mathrm{L}$, 2-30 $\mu \mathrm{L}, 3-50 \mu \mathrm{L}, 4-80 \mu \mathrm{L}, 5-100 \mu \mathrm{L}, 6-120 \mu \mathrm{L}$. 
The drop in absorbance is proportional to the amount of DPPH oxidized form that remains in solution. The color change from purple to yellow can be monitored spectrophotometrically and utilized for the assessment of the free radical scavenging potential of many antioxidants and natural products. For the first time, the colorimetric method was described by Blois [177] for the evaluation of the antioxidant properties of the thiol-containing amino acid cysteine as the model antioxidant. Since that time, an easy and convenient colorimetric method has been extensively used to evaluate the antioxidant capacity of many products of natural origin [178-183]. The reaction of DPPH with antioxidants was adapted for illustration and measuring the kinetics of radical quenching [184,185]. Since the beginning of the 1960s, the method, as well as antioxidant activity calculations, have evolved into numerous modifications [186,187].

\section{DPPH Free Radical Scavenging Kinetics}

DPPH free radical scavenging has been conducted by using at least two commonly practiced procedures (a) fixed reaction time, when the researcher imposes reaction times of 15,30 , or $60 \mathrm{~min}$, and (b) steady-state saturation one, when the reaction time is related to the reaction kinetics. The reaction of DPPH radicals with antioxidants is a kinetically driven process. It has been proven that the time required to reach saturation state, i.e., the highest decrease in DPPH absorbance depends on concentration and the kind of antioxidant. To check out the kinetic behavior of the disappearance of DPPH radicals with individual antioxidants, kinetic scans should be performed at different concentration levels. Although at higher concentrations, the scavenging capacity is higher, sometimes the reaction cannot be completed quickly because of slow kinetics. For instance, the reaction of DPPH with ascorbic acid is fast and achieves completion within a minute [188], whereas even $3 \mathrm{~h}$ is not enough to finish the reaction for curcumin at so small a concentration as from 5 to $15 \mu \mathrm{M}$. In turn, the reaction time for BHT was found to be around $6 \mathrm{~h}$. Such antioxidants as lipoic acid, melatonin, and pentoxifylline demonstrate slow reaction with DPPH radical up to $2 \mathrm{mM}$. Such kinetic measurements have been performed for different chemicals used as reference antioxidants. Considering the time duration of reaction to achieve the steadystate, antioxidants can be divided into categories of fast ( $<30 \mathrm{~min}$ ), medium ( $30 \mathrm{~min}$ to $1 \mathrm{~h}$ ), and slow (>1 h) kinetics. In 2012, Mishra et al. [178] established the nature of individual chemicals such as alpha-tocopherol, ascorbic acid, sesamol, gallic acid, ferulic acid, and BHT-butylated hydroxytoluene, which are commonly used as references in the comparative evaluation of antioxidant properties. Among these reagents, there are examples of fast (ascorbic acid), medium (gallic acid), and slow reaction kinetics, which is observed for BHT. Despite the fact that the time to attain an equilibrium state depends on the nature of antioxidants, researchers have usually chosen a fixed reaction time mode where reaction time is pre-imposed to be $20-30 \mathrm{~min}$ instead of the real-time required to attain completion of the redox reaction [176], ignoring their kinetic behavior and the fact that many antioxidants might react with different kinetics or might not react at all. Furthermore, some authors emphasize the reversibility of the free radical reduction by antioxidants, which results in underestimation of the antioxidant capacity of many antioxidants [106,189].

Considering numerous methodologies of DPPH assay described in the literature, involving variation in (i) concentrations of reagents, (ii) sample' volume, (iii) the kind of reference molecules, (iv) antiradical parameters used, (v) units of applied parameters, and (vi) the kind of sample environment (methanol or semi-aqueous media), the antiradical potential of any sample assessed by DPPH assay, it is very difficult to compare results between laboratories. Mishra et al. [134] collected $\mathrm{IC}_{50}$ values of reference standards such as butylated hydroxyl anisole (BHA), ascorbic acid, gallic acid, BHT, and Trolox that determined by different authors. It appeared that the reported $\mathrm{IC}_{50}$ value of ascorbic acid was in the range from 11.85 to $629 \mu \mathrm{M}$. Unfortunately, such a large variation in $\mathrm{IC}_{50}$ values was also observed for remaining antioxidants. Recently, Xie and Schaich [190] have reevaluated the DPPH assay considering the solvent kind and $\mathrm{pH}$ values. 


\section{Parameters Used to Express the Antioxidant Potential}

The DPPH free radical scavenging activity is commonly expressed in terms of the percentage of inhibition of the free radical by examined antioxidants. The $\mathrm{EC}_{50}$ value relates to the antioxidant concentration required to achieve a 50\% decrease in the DPPH absorbance. This parameter is typically employed not only to express the antioxidant capacity but also to compare the activity of different compounds with each other. To find the above parameter, antiradical curves are plotted, representing the relationship between the concentration of antioxidants on the $x$-axis and relative scavenging capacity $(\mathrm{E} \%)$ on the y-axis. The radical scavenging capacity can be calculated using the following equation:

$$
\text { Percentage effect }(\mathrm{E} \%)=\frac{\left(\mathrm{Abs}_{\text {control }}-\mathrm{Abs}_{\text {sample }}\right)}{\mathrm{Abs}_{\mathrm{control}}} \times 100 \%
$$

However, to find the most credible $\mathrm{EC}_{50}$ value, an assay should be done using several antioxidant concentrations located near the estimated $\mathrm{ED}_{50}$ value. The above graph looks like a typical rectangular hyperbole, but it can be changed into a sigmoidal curve after the logarithmic transformation of the $\mathrm{x}$-axis $(\log [\mathrm{mol} / \mathrm{L}])$. The $\mathrm{EC}_{50}$ value is usually located in a short linear range, and it may be calculated by the use of the right-angled triangle [191,192]. This mathematical method must meet two assumptions: reaching the maximum response and recording at least two points located near the targeted point of the $50 \%$ maximal response. The following equation enables $\mathrm{EC}_{50}$ value calculation:

$$
\mathrm{EC}_{50}=\mathrm{D}-\frac{(\mathrm{A}-50 \% \text { max.response }) \times(\mathrm{D}-\mathrm{C})}{(\mathrm{A}-\mathrm{B})}
$$

It should be noted that sigmoid curves based on the Hill equation are easier to interpret [193]. The logarithmic curve does not have to be symmetrical around its midpoint, thanks to the model using the Richards equation which provides a fitting thanks to the introduction of the $S$ parameter, quantifying the asymmetry. Chen et al. [192] conducted a comparative study of several specialized computer programs based on various regression models towards the aim of $\mathrm{EC}_{50}$ estimation. The $\mathrm{EC}_{50}$ values obtained by the use of the statistical programs were similar to each other; however, GraphPad Prism@ five-parameter analysis showed the smallest variance in relation to the experimental estimated $\mathrm{EC}_{50}$. The authors claim that the observed differences in the results between the statistical processing programs GraphPad and SigmaPlot are due to the fact that the first one calculates actual $\mathrm{EC}_{50}$ values, while the second gives the inflection point as the $\mathrm{EC}_{50}$.

Antiradical power (ARP) is another parameter that can be used to define antioxidant activity. This parameter is defined as a reciprocal of $\mathrm{EC}_{50}$, which is why the higher value of $\mathrm{EC}_{50}$ is related to smaller antiradical power:

$$
\mathrm{ARP}=\frac{1}{\mathrm{EC}_{50}}
$$

The antioxidant capacity can be expressed as reference chemical equivalent such as Trolox ( $\mu \mathrm{mol} \mathrm{TE} / \mathrm{g})$, ascorbic acid, gallic acid (GAE/g), etc. Unfortunately, comparison of results presented by different studies is difficult because of the variety of units used for the above recalculations. We can find mass/mass units such as milligrams per gram of dry material, $\mu \mathrm{mol} / \mathrm{g}$, or mass/volume ones.

\section{DPPH Assay Approaches}

In the original DPPH assay, provided by batch experiments, several automation approaches based on flow injection analysis (FIA) [194,195] and sequential injection analysis (SIA) [196] have been proposed in recent decades. An interesting approach inspired by HPLC-FIA [197] has been elaborated on by Koleva [198]. In this method, the HPLCseparated analytes react postcolumn with the DPPH solution, and the induced bleaching is 
detected as a negative peak by the second detector at $517 \mathrm{~nm}$. Cerda et al. [199] described multi-syringe flow injection analysis (MSFIA) for determining the total antioxidant capacity of several food products. Flow injection analysis (FIA), similarly to sequential injection analysis (SIA), is beneficial for rapid testing of antioxidation/radical scavenging activity of large series of multicomponent samples [177]. Another advantage of automatic approaches in comparison to the standard spectrophotometric batch experiments lies in the visible improvement of measurement reproducibility. Another assay suitable for screening of either hydrophilic or lipophilic antioxidants is a high-throughput relative DPPH radical scavenging capacity (RDSC) assay elaborated by Cheng et al. [189]. The assay, which can be performed in aqueous and organic environments, utilizes a 96-well microplate reader with the spectrophotometric detector, ensuring acceptable accuracy, precision, and reproducibility.

The sophisticated instruments are required not only for the rapid determination of the antioxidant activity of complex mixtures but also for providing separation and identification of the selected antioxidant compounds. The HPLC method appears to be the method of choice in this case. For this purpose, HPLC should be used in combination with an appropriate detector, which is usually connected online to chromatographic apparatus. However, simultaneous determining of antioxidant capacity requires additional coupling with another radical scavenging detection mode. Such systems have been described in the literature; unfortunately, they are not adopted commonly due to their complexity and the lack of commercial availability. As an example, in 2007, Wu et al. [200] developed HPLC-ESI-MS and NMR for estimation of antioxidant capacity of polyphenolic acids in the plant extract. In turn, Nuengchamnong et al. [201] proposed RP-HPLC coupled with an electrospray ionization MS/MS system for the identification of antioxidant compounds in an extract of a Thai medicinal plant. An interesting HPLC approach, suitable for searching natural antioxidants in plant extract of Flos Lonicerae Japonicae, was developed by Tang et al. in 2008 [202]. The method's idea assumes that the peak areas of compounds with antioxidant activity undergo reduction after reaction with DPPH. The authors performed additional identification of antioxidants by the HPLC-DAD-TOF/MS hyphenated technique.

Traditional thin-layer chromatography with post chromatographic derivatization using DPPH solution for free radical scavenging activity evaluation, discovered by Glavind and Holmer in 1967 [203], exists nowadays in the modern version owing to video scanning technology [204].

\subsubsection{Electrochemical Methods}

Electrochemical measurements possess some major advantages in comparison to spectrophotometric methods mainly due to the fact that they are fast, less tedious, cheaper, and safer for the environment. They include electrochemical techniques of antioxidant characterization as potentiometry, amperometry, biamperometry, cyclic voltammetry (CV), square-wave voltammetry (SWV), and differential pulse (DPV). These methods utilize the fact that antioxidants are involved in redox reactions acting as reducing agents. The electrochemical techniques are able to measure their redox potentials.

\section{The Cyclic Voltammetry Method}

The cyclic voltammetry method is applied to screen the reducing capacity of the samples. Cyclic voltammetry (CV) operates due to the combination of three electrodes, namely working electrode, reference, and auxiliary electrode. A polarogram representing the relationship between current intensity and an increasing potential applied to the working electrode is recorded. The obtained voltammograms show well-defined voltammetric peaks corresponding to the oxidation and reduction processes. Lower Epa values are associated with the higher reducing activity of the tested sample. Therefore, considering the first oxidation potential, the following classes of chemical compounds can be distinguished: if Ep is lower than $0.8 \mathrm{~V}$, antioxidant power is high, and if Ep is between 0.8 and $1.3 \mathrm{~V}$, antioxidant power is low [205]. The area under the curve of the voltammetric peak 
(AUC) corresponds to the concentration of antioxidants. Broad anodic peaks are usually observed due to the response of multiple reducing agents with different oxidation potentials present in the respective extracts. In such cases, Chevion et al. [206]. Martinez et al. [207], and Zielińska and Zieliński [208] suggested that the area under the anodic current wave should be used for the evaluation of reducing the power of the samples. Lower AUC indicates a lower reducing capacity of the investigated extract. Usually, the reducing capacity is statistically significantly correlated with the active components of the extracts. Zielińska et al. [209] found the existence of a significant positive correlation between the total phenolic content $(\mathrm{r}=0.867 ; p<0.01)$ and total flavonoid content $(\mathrm{r}=0.752, p<0.01)$ with the reducing capacity of peels of the investigated apple cultivars.

\section{Biamperometry}

Determination of the antioxidant activity by biamperometric measurements is based on a high degree of reversibility redox couple potential, including $\mathrm{Fe}^{3+} / \mathrm{Fe}^{2+}, \mathrm{I}_{2} / \mathrm{I}^{-}$, $\mathrm{Br}_{2} / \mathrm{Br}^{-}, \mathrm{VO}_{3-} / \mathrm{VO}_{2}{ }^{-} \mathrm{Fe}(\mathrm{CN})_{6}{ }^{3-} / \mathrm{Fe}(\mathrm{CN})_{6}{ }^{4-}$, and $\mathrm{Ce}(\mathrm{IV}) / \mathrm{Ce}(\mathrm{III})$. The $\mathrm{DPPH}{ }^{\bullet} / \mathrm{DPPH}$ couple is also suitable for this purpose. The current intensity is proportional to the decreasing concentration of free radicals after reaction with the antioxidants. The obtained results of antioxidant activity are usually in very good agreement with those determined by the use of other conventional methods such as spectroscopic measurements. The biamperometric technique was applied by Milardovic et al. [210] for evaluation of the selected standard antioxidants (ascorbic acid, uric acid, gallic acid, $\mathrm{N}$-acetyl-l-cysteine, glutathione, caffeic acid, ferulic acid, sinapic acid, catechin hydrate, quercetin) and food samples such as coffee, tea, wine, and juices.

\subsubsection{Nanoparticle-Based Approach for the Antioxidant Activity Measurement}

More recently, the new nanoparticle-based approach for evaluation of antioxidant activity has been reported. This approach utilizes the unique optical, electronic, and catalytic properties of metallic nanoparticles (1-100 nm) [211-214].

For the first time, Scampicchio et al. [117] described a nanoparticle-based method for measuring antioxidant activity. The idea of the method was based on the catalytic growth of gold $(\mathrm{Au})$ NPs mediated by phenolic acids as active reducing agents (vanillic acid, propyl gallate, protocatechuic acid, caffeic acid, ferulic acid). It appeared that the antioxidant (reducing) power of the phenolic acids was correlated with the optical properties of generated nanoparticles. The absorbance characteristic of the plasmon of the Au NPs (555 nm) was linearly dependent upon the concentration of the investigated phenolic acids. The authors confirmed the good agreement between the total phenolic content estimated by the Folin-Cicolteau spectrophotometric determination and the results of the Au NPs protocol.

A few years later, Özyürek et al. [118] elaborated on a sensitive colorimetric method based on the reduction of $\mathrm{Ag}+$ ions to silver nanoparticles (AgNPs) for the detection of polyphenols. The AgNPs revealed the absorption band at $423 \mathrm{~nm}$, allowing the quantification of the polyphenols. The initial seeds were formed by the reduction of silver ions with trisodium citrate. The addition of antioxidants as secondary reductants caused the reduction of $\mathrm{Ag}+$ ions on silver seeds and the deposition of more $\mathrm{Ag}$ atoms on the seeds, resulting in the final core-shell AgNP structures. The growth of AgNPs on monodisperse seed particles caused a linear, concentration-dependent absorbance increase. The method was named by the research group "Silver NanoParticle Antioxidant Capacity", abbreviated as the SNPAC method, which is recommended for measuring the total antioxidant capacity (TAC) of a wide range of plant samples (Figure 5).

Until now, most assays applied for antioxidant capacity determination have involved the use of NPS of gold, silver, $\mathrm{Fe}_{3} \mathrm{O}_{4}$, quantum dots, and titania nanoparticles. The estimation of antioxidant activity relies on the antioxidant-mediated growth of NPs, monitoring changes in NPs size, changes in surface oxidation states, the degree of agglomeration of nanostructures, and optical monitoring of the plasmon absorption bands. AuNPs are 
still the most commonly used for that purpose. AuNPs have a very characteristic absorbance peak at $517 \mathrm{~nm}$. AuNPs are soluble and stable in different solvents such as water, dichloromethane, or methanol. NPs formation can be monitored visually owing to AuNPs' color, which depends on their shape and size, but also surface-adsorbed species, the refractive index of the dispersion medium, and interparticle interactions [215]. Different techniques have been engaged for detection and characterization of NPs such as the localized surface plasmon resonance (SPR), Surface-Enhanced Raman Scattering, spectrophotometry, Fourier Transform Infrared Spectroscopy (FTIR), Resonance Light Scattering, Raman spectroscopy, X-ray diffraction (XRD), and transmission electron microscopy (TEM) [216]. Selected methods suitable for measuring size, electric and mechanical properties, size distribution, hydrodynamic radius, elemental composition, and quantitative analysis of nanoparticles together with the methods' detection limits are illustrated in Figure 6.
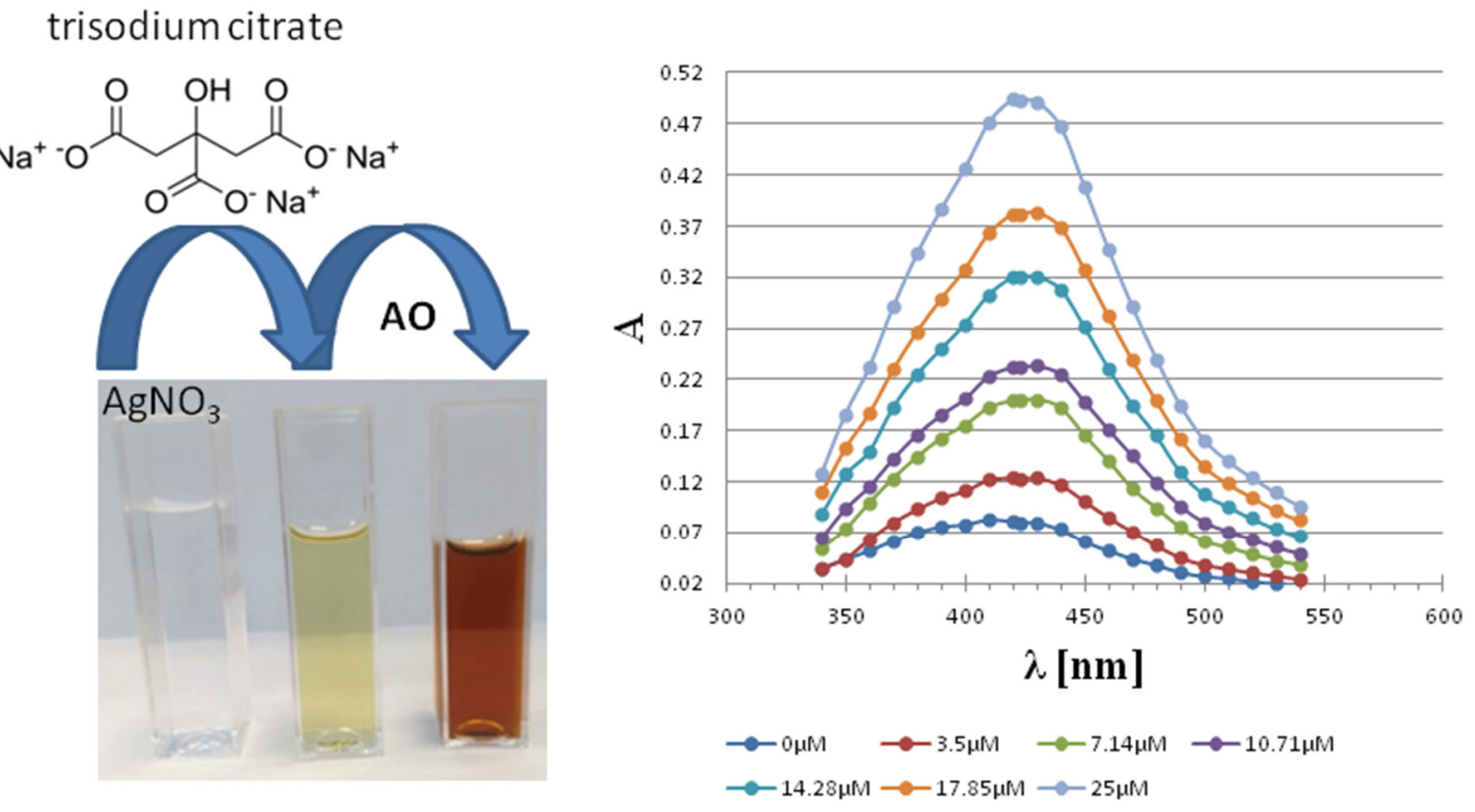

Figure 5. Scheme illustrating the idea of Silver NanoParticle Antioxidant Capacity (SNAPC) Assay. On the left side, sample preparation steps; on the right side, surface plasmon resonance absorption of citrate-stabilized AgNPs. Absorption is intensified by the addition of increasing ascorbic acid (AO) concentration, which corresponds to NPs growth.

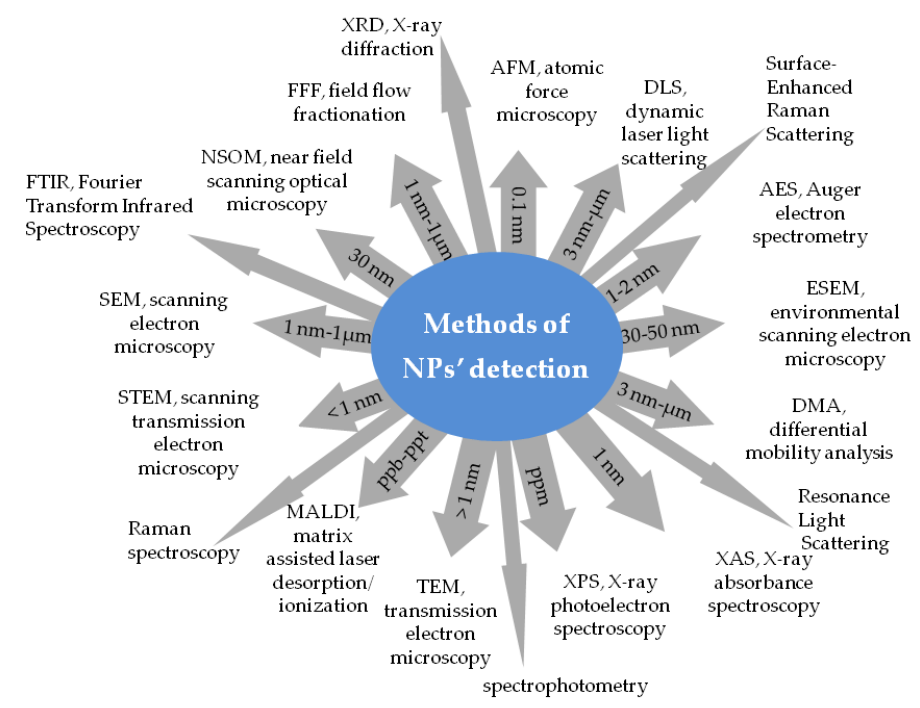

Figure 6. Selected methods applied to detection of nanoparticles together with detection limits [217]. 
Since nanoparticles-based assay is a new analytical tool, calibration is usually performed using control antioxidants [218-221], and additionally, the assay is compared with reference methods, e.g., ORAC and TEAC. Many authors achieved very good agreement between the TAC values obtained by the nanoparticle-based approach and the Trolox Equivalent Antioxidant Capacity (TEAC), CUPRAC [222], Folin-Ciocalteu, FRAP, and DPPH [218] as reference tests.

Antioxidant capacity determination by nanoparticles-based method also involves other metallic or metal oxide NPs. Gatselou et al., in 2016 [223], reported that phenolic compounds (i.e., gallates, catechins, dihydroxybenzoic acids, and cinnamates) generate changes in the localized surface plasmon resonance of rhodium NPs, causing characteristic spectral and color transitions in their suspensions. Under the influence of the reaction between phenolic compounds and rhodium, absorbance at $450 \mathrm{~nm}$ and $580 \mathrm{~nm}$ increased linearly together with increasing concentration of antioxidants in the range of 0-500 $\mu \mathrm{M}$.

Recently, antioxidant activity (AOA) assays using cerium oxide nanoparticles (CeO$\mathrm{NPs}$ ) as a novel colorimetric sensor were developed. Cerium oxide nanoparticles (CeO-NPs) may act as both an oxidant and an anti-oxidant, switching between trivalent and tetravalent oxidation states [224]. In 2018, Ozdemir Olgun [225] elaborated on a novel colorimetric sensor consisting of the poly(acrylic acid) sodium salt (PAANa)-coated CeO-NPs which oxidized a peroxidase substrate, namely tetramethyl benzidine (TMB) in acidic conditions to charge-transfer complex of a blue color. The analytical wavelength of the colored product was estimated at $651 \mathrm{~nm}$. The antioxidant activity evaluation was based on the measurement of decreasing intensity of the nanoceria suspension absorbance caused by antioxidants. The authors demonstrated that the antioxidant capacities of hydrophilic and lipophilic antioxidants such as rutin, tetramethyl benzidine, quercetin, ascorbic acid, Trolox (6-hydroxy-2,5,7,8-tetramethylchroman-2-carboxylic acid), ferulic acid, BHT, caffeic acid, and catechin estimated by the above procedure were compatible with those of reference assays ABTS, CUPRAC, and CERAC [225]. Currently, portable nanoparticle-based tests for rapid detection of food antioxidants (NanoCerac) are being developed, e.g., for nanoparticles of immobilized cerium oxide [226], or nanoparticles of metal oxides $\mathrm{TiO}_{2}, \mathrm{Fe}_{2} \mathrm{O}_{3}, \mathrm{ZrO}_{2}$, $\mathrm{ZnO}$, and $\mathrm{SiO}_{2}$, which are immobilized on cellulose [227]. Several reviews regarding TAC determination by using NPs can be found in the literature [228-232].

\section{Antioxidant Capacity of Extracts from Natural Sources}

Epidemiological research confirms that the conditions related to oxidative stress can be improved by the consumption of food products rich in numerous compounds with high antioxidant activity $[233,234]$. Natural products containing at least $0.1 \%$ of antioxidants can be accepted as dietary supplements with antioxidant properties.

As the total antioxidant capacity (TAC) covers the additive (synergistic/antagonistic) action of different antioxidants of complex samples, most researchers use this parameter to assess plant-based extracts rather than the separate determination of the concentrations of the individual constituents. It should be emphasized that antioxidant capacity reflects the thermodynamic conversion efficiency of reactive species by antioxidants in contrast to the antioxidant activity, which is related to the kinetics of this reaction, usually expressed scavenging percentages per unit time. Unfortunately, many phytochemical studies have reported conflicting results, which is why TAC assays still require consideration and standardization in the following issues: (i) procedures of sample preparation, (ii) expressing results, (iii) statistical validation (e.g., using certified reference compounds that take into account the different reaction kinetics), and (iv) establishing effects of solvent, concentration, $\mathrm{pH}$, etc.

The choice of extraction techniques has the greatest impact on the composition and concentration of the bio-composition of both active compounds and matrix components obtained from a wide range of plant materials (herbs, vegetables, berries, and fruits) [235]. It has been shown that different extraction methods lead to different extraction yields on the same plant material [236]. For example, Lisitsyn et al. [237] studied the plant 
extracts (rosemary, black pepper, thyme, and sage) obtained by the use of supercritical $\mathrm{CO}_{2}$ extraction. Owing to this extraction method, they produced extracts with a significantly different composition in comparison to those obtained in traditional ways. It appeared that supercritical extracts were rich in a variety of substances with high antioxidant, and antimicrobial activities such as alkaloids, terpene, phytosterols, waxes, pigments, high molecular weight unsaturated and saturated fatty acids, and vitamins.

Currently, classic extraction techniques, i.e., Soxhlet extraction, maceration, percolation, and distillation, which use large amounts of volatile organic solvents, or elevated temperature, are less frequently used due to the requirements of the so-called "green chemistry", poor efficiency, and possible thermolability of extracted analytes [238]. High extraction efficiency and effectiveness are possible thanks to the use of unconventional techniques, i.e., Solid Phase Microextraction (SPME), Supercritical Fluid Extraction (SFE), Microwave-Assisted Extraction (MAE), Pulsed-Electric Field (PEF) Extraction, UltrasoundAssisted Extraction (UAE), and Enzymatic Treatment or Pressurized Liquid Extraction (PLE). It should be remembered that antioxidant capacity changes not only in relation to the extraction techniques but varies with the growth period and drying methods and between plant parts. These factors' influence has been confirmed by a multivariate analysis performed by Buitrago et al. [239] using Chenopodium quinoa Willd.

Plant-derived compounds possess well-known and established antioxidant activity. However, the microbes are also efficient producers of primary and secondary metabolites with specific antioxidant potential [240]. Thus far, microbial metabolites have been recognized as efficient remedies against fungal and bacterial infections (tetracyclines, amphotericin, penicillins, erythromycins, streptomycin, and vancomycin), cancer (daunorubicin, bleomycin, mitomycin, doxorubicin,), transplant rejection (rapamycin, cyclosporine), or high cholesterol (mevastatin, lovastatin) [241].

Almost all eubacteria possess the ability to produce a variety of extracellular metabolites with significant antioxidant activity, such as thiazostatins A, phenazoviridin, (Z)-1-((1hydroxypenta-2,4-dien-1-Yl)oxy)anthracene-9,10-dione, 5-(2,4-dimethyl benzyl) pyrrolidin2-one, benthophoenin, benzastatins C, benthocyanins A, B, C, exopolysaccharides (EPS), and benzastatins A [78]. Exopolysaccharides (EPS) are produced by numerous strains of microorganisms belonging to the genera Lactobacillus, Leuconostoc, Lactococcus, and Streptococcus, which are abbreviated LAB (Lactic Acid Bacteria) [54]. EPS are characterized by the presence of reactive functional groups including aldehyde, hydroxyl, and ketone groups. They can efficiently react with free radicals. These compounds have a polymeric structure. They are made up of repeating subunits of connected carbohydrates $\alpha$ - and $\beta$-glycosidic bonds. Homopolysaccharides are composed of one type of simple sugar, i.e., glucose or fructose, while heteropolysaccharides are more complex. The structure of individual heteropolysaccharides produced by particular species and strains of these bacteria can significantly vary. A common feature of most of them is occurrence in the composition of sugars e.g., rhamnose, arabinose, mannose, xylose, fructose, glucose, and galactose, in various ratios [242]. The EPS may exist in two forms: a cell-bound exopolysaccharide (c-EPS) that strongly binds to the bacterial surface and a released exopolysaccharide (r-EPS) that can be released into the medium [243].

Cyanobacteria and blue-green algae are sources of a significant amount of free radical scavengers such as carotenoids, phycocynanin which are water-soluble pigments possessing $\mathrm{N}-\mathrm{H}$ reactive groups. Astaxanthin produced by microalga Haematococcus pluvialis possessing several times higher antioxidant activity in comparison to vitamin E [244,245]. Algae are able to produce also other phenolic compounds with reactive $\mathrm{OH}$ moieties responsible for an antioxidant activity like carrageenan, bromophenol, fucophlorethols, galactan sulphate, phlorotannins, fucoxanthin, phycoerythrin, shinorine, catechin, por-phyran, epicatechin, gallate, laminaran, vitamin A, alginic acid, phloroglucinol, eckol, fucodiphlorethol G, 7-phloroeckol, dieckol, phlorofucofuroeckol A, 6,60-bieckol, 2,70-phloroglucinol-6,60bieckol, and triphlorethol-A, [246-248]. As a potential antioxidant, phycobilins rich with groups i.e., $\mathrm{N}-\mathrm{H}, \mathrm{COOH}, \mathrm{C}-\mathrm{O}$, and $\mathrm{O}-\mathrm{H}$ produced by cyanobacteria have been described. 
However, efficient extraction and purification are required for the recovery of phycobiliproteins on an industrial scale [249]. In 2019, the Special Issue of Antioxidants focused on recent investigations concerning marine algal antioxidants and specific antioxidant networks functioning in algae [248-259].

Lichens produce various extracellular, secondary metabolites that can be used as potential sources of natural antioxidants [260]. At the beginning of the 21st century, the significant free radical scavenging activity of Cetraria islandica aqueous extracts [261] and Usnea ghattensis [262] methanolic extracts of Platismatia glauca, Parmelia saxatilis, Ramalina pollinaria, Umbilicaria nylanderiana, and Ramalina polymorpha [263] were described. Fernández-Morianoet et al. [264] prepared a systematic review concerning the key antioxidant compounds in lichens extracts. It appeared that flavonoids and phenols are mainly responsible for the antioxidant activity of the examined extracts [265-268]. Some of them also exhibited beneficial antimicrobial and anticancer activities [269,270].

Actinomycetes also produce chemically diverse and pharmaceutically useful compounds with antifungal, antibacterial, diabetogenic, antiviral, immunosuppressive, antiparasitic, antitumor, insecticidal, antioxidant, anti-inflammatory, enzyme inhibitory, and others [271]. Actinomycetes originating from different habitats usually manifest very different antioxidant activity [272-277]. Published studies show that nitrogen-containing metabolites, such as the carbazole and phenazinylhetero cycles, constitute the main group of antioxidant compounds produced by Streptomyces spp. Stealthins contain $\mathrm{OH}, \mathrm{NH}$, and $\mathrm{CO}$ groups isolated from S. Aeriouvifer, S. Violaceus, and S. viridochromogenes showed even several dozen times stronger activity than vitamin E [278].

Other examples of antioxidant capacity assessment of the different extracts from plants, lichens, fungi, algae, and actinomycetes are collected in Table 3.

Table 3. Examples of antioxidant capacity assessment of extracts obtained from different species.

\begin{tabular}{|c|c|c|c|c|}
\hline Analysed Product & $\begin{array}{c}\text { Antioxidant } \\
\text { Assays }\end{array}$ & $\begin{array}{l}\text { Positive } \\
\text { Control }\end{array}$ & Extraction Procedure & Ref. \\
\hline \multicolumn{5}{|c|}{ Plants } \\
\hline Bryonia alba L. & $\begin{array}{l}\text { DPPH, CUPRAC, } \\
\text { FRAP, TEAC, } \\
\text { SNPAC }\end{array}$ & quercetine, BHT, Trolox & $\begin{array}{l}\text { Fifty grams of powder was macerated with } \\
500 \mathrm{~mL} \text { methanol for } 24 \mathrm{~h} \text {. After percolation, } \\
\text { extract was evaporated under vacuum at } 40^{\circ} \mathrm{C} \text {. }\end{array}$ & [279] \\
\hline $\begin{array}{l}\text { Cistus ladanifer L., Cistus } \\
\text { salvifolius L., Cistus albidus L., } \\
\text { Erica australis L., Arbutus } \\
\text { unedo L., Pistacia lentiscus L. }\end{array}$ & $\begin{array}{l}\text { DPPH, FRAP, } \\
\text { ABTS, RP }\end{array}$ & quercetin & $\begin{array}{l}\text { Twenty grams of grounded leaves was mixed } \\
\text { with } 200 \mathrm{~mL} \text { of methanol. The mixture was } \\
\text { kept for } 24 \mathrm{~h} \text { at RT. Then, it was filtered. }\end{array}$ & [280] \\
\hline $\begin{array}{l}\text { Prunus avium, Prunus persica, } \\
\text { Prunus domestica, Olea } \\
\text { europeae, Pirus communis, } \\
\text { Pirus maus, Pistacia verra, } \\
\text { Castanea sativa }\end{array}$ & $\begin{array}{l}\text { DPPH, FRAP, } \\
\text { TAC }\end{array}$ & Trolox, ascorbic acid & $\begin{array}{l}\text { Two grams of sample was mixed with } 60 \% \\
\text { methanol and kept } 1 \mathrm{~h} \text { at dark at RT. The } \\
\text { procedure was repeated two times. The } \\
\text { combined extracts were centrifuged and filled } \\
\text { to } 50 \mathrm{~mL} \text { by aqueous methanol. }\end{array}$ & [281] \\
\hline $\begin{array}{l}\text { Vitis vinifera } \mathrm{L} . \\
\text { (Maraština, Pošip; Lasin, } \\
\text { Merlot, Syrah, Vranac) }\end{array}$ & DPPH, FRAP & Trolox & $\begin{array}{l}\text { The dry plant material }(20 \mathrm{~g}) \text { was extracted } \\
\text { using } 100 \mathrm{~mL} \text { of ethanol } / \text { water } 80 / 20,(\mathrm{v} / \mathrm{v}) \text { at } \\
60^{\circ} \mathrm{C} \text {, for } 60 \mathrm{~min} \text {. The extract was filtered and } \\
\text { dried under a vacuum at } 50^{\circ} \mathrm{C} \text {. The dry } \\
\text { residues were redissolved with } 50 \% \\
\text { methanol-water and centrifuged at } 5000 \mathrm{rpm} \\
\text { for } 10 \mathrm{~min} \text {. }\end{array}$ & [282] \\
\hline Ornithogalum billardieri & $\begin{array}{l}\beta \text {-carotene-linoleic acid } \\
\text { assay, ABTS, } \\
\text { MCA/ferrous ion, } \\
\text { TAC/ } \mathrm{H}_{2} \mathrm{SO}_{4}, \mathrm{Na}_{3} \mathrm{PO}_{4} \\
\left.\left(\mathrm{NH}_{4}\right)_{2} \mathrm{MoO}_{4}\right)\end{array}$ & ascorbic acid & $\begin{array}{l}\text { The combined maceration with sonication } \\
\text { either at } 25^{\circ} \mathrm{C} \text { for } 50 \% \text { ultra-sound (US) } \\
\text { treatment or the extract obtained under the } \\
\text { optimal conditions: extraction time: } 37.1 \mathrm{~min} \text {, } \\
\text { temperature: } 44.2{ }^{\circ} \mathrm{C} \text {, water volume-to-mass } \\
\text { ratio: } 33.8 \mathrm{~mL} / \mathrm{g} \text {, and US\%:51.7\% }\end{array}$ & [283] \\
\hline
\end{tabular}


Table 3. Cont.

\begin{tabular}{|c|c|c|c|c|}
\hline Analysed Product & $\begin{array}{l}\text { Antioxidant } \\
\text { Assays }\end{array}$ & $\begin{array}{l}\text { Positive } \\
\text { Control }\end{array}$ & Extraction Procedure & Ref. \\
\hline $\begin{array}{l}\text { Apple cultivars: } \\
\text { antonówka, delikates, Early } \\
\text { Geneva, papierówka, } \\
\text { Paulared, Sunrise, Quinte } \\
\text { Gloster, Jonagored, } \\
\text { Ligol, Rubinola }\end{array}$ & $\begin{array}{l}\text { DPPH, FRAP, } \\
\text { MCA/ferrous ion }\end{array}$ & Trolox, catechin & $\begin{array}{l}\text { The material was lyophilized. A total of } 250 \mathrm{mg} \\
\text { of sample was extracted by sonication using } \\
1 \mathrm{~mL} \text { of } 80 \% \text { methanol for } 30 \mathrm{~s} \text {. Then, the } \\
\text { mixture was vortexed, centrifuged for } 5 \mathrm{~min} \\
(13,200 \mathrm{rpm}) \text {, and sonicated. The extraction } \\
\text { procedure was repeated five times. The } \\
\text { supernatants were collected together. }\end{array}$ & [209] \\
\hline Fraxinus angustifolia Vahl & $\begin{array}{l}\text { TAC/Folin-Ciocalteu, } \\
\text { FRAP, ABTS, DPPH }\end{array}$ & $\alpha$-tocopherol & $\begin{array}{l}\text { Manna samples }(10 \mathrm{~g}) \text { were dissolved in } \\
\text { methanol-water }(2: 1) \text { and extraction carried out } \\
\text { at } 25 \pm 2^{\circ} \mathrm{C} \text { and in darkness for } 1 \mathrm{~h} \text {., and } \\
\text { centrifuged ( }(3000 \mathrm{~g}, 10 \mathrm{~min}) \text {. The supernatants } \\
\text { were filtered and evaporated at } 35^{\circ} \mathrm{C} \text {. Dried } \\
\text { samples were resuspended in } 5 \mathrm{mM} \text { phosphate } \\
\text { buffer saline pH } 7.4 \text {. }\end{array}$ & {$[284]$} \\
\hline Chenopodium quinoa & DPPH, FRAP & Trolox, gallic acid & $\begin{array}{l}\text { Dry plant materials (roots, leaves, stems, } \\
\text { flowers, and seeds) were extracted by the use of } \\
\text { ultrasound-assisted extraction with } 96 \% \\
\text { ethanol. The extracts were concentrated under } \\
\text { reduced pressure in a rotary evaporator. }\end{array}$ & {$[239]$} \\
\hline $\begin{array}{l}\text { Lycium barbarum, } \\
\text { Lyciumchinense }\end{array}$ & DPPH, ABTS & - & $\begin{array}{l}\text { Samples were dried, powdered, and dissolved } \\
\text { in distilled water. }\end{array}$ & {$[285]$} \\
\hline Aegopodium podagraria $\mathrm{L}$. & DPPH & GSH, ascorbic acid & $\begin{array}{l}\text { A total of } 2.5 \mathrm{~g} \text { of air-dried or fresh aerial parts } \\
\text { was extracted by } 100 \mathrm{~mL} \text { of } 80 \%(\mathrm{v} / \mathrm{v}) \text { ethanol. } \\
\text { The samples were kept at RT for } 3 \text { days, three } \\
\text { months in dark, or in an ultrasonic bath for } \\
60 \mathrm{~min} \text {. Then, the extracts were filtered. }\end{array}$ & {$[286]$} \\
\hline \multicolumn{5}{|c|}{ Fungi } \\
\hline Achaetomium sp. & $\mathrm{DPPH}$ & $\begin{array}{l}\text { ascorbic acid, BHT, } \\
\text { gallic acid, pyrogallol }\end{array}$ & $\begin{array}{l}\text { The organic ethyl acetate extract was } \\
\text { evaporated. The crude extract was dissolved } \\
\text { in DMSO. }\end{array}$ & [287] \\
\hline $\begin{array}{l}\text { Acremonium charticola, } \\
\text { Rhizopus oryzae }\end{array}$ & ABTS & ascorbic acid & $\begin{array}{l}\text { Fungi were cultured in potato dextrose broth at } \\
37^{\circ} \mathrm{C} \text {. After } 3 \text { days, the cultures were } \\
\text { centrifugated at } 5000 \mathrm{rpm} \text { for } 10 \mathrm{~min} \text {. The } \\
\text { filtrate }(1 \mathrm{~g}) \text { was mixed with } 100 \mathrm{~mL} \text { methanol } \\
\text { and ultrasonicated for } 30 \mathrm{~min} \text {. The homogenate } \\
\text { was created for three days at RT. Then, it was } \\
\text { evaporated with a rotary vacuum evaporator } \\
\left(50^{\circ} \mathrm{C}, 100 \mathrm{rpm}\right) \text { to the volume of } 25 \mathrm{~mL} \text {. }\end{array}$ & [288] \\
\hline $\begin{array}{l}\text { Agaricus bisporus, Pleurotus } \\
\text { ostreatus, Pleurotus eryngii, } \\
\text { Lentinula edodes }\end{array}$ & $\begin{array}{l}\text { TPC/Folin-Ciocalteu, } \\
\text { Ferricyanide/prussian } \\
\text { blue, } \\
\text { DPPH, TBARS } \\
\beta \text {-carotene/linoleate }\end{array}$ & Trolox, gallic acid & $\begin{array}{l}\text { The product was lyophilized. The obtained } \\
\text { powder was mixed with methanol and kept at } \\
25^{\circ} \mathrm{C} \text { at } 150 \mathrm{rpm} \text { for } 1 \mathrm{~h} \text {. Then, the mixture was } \\
\text { and filtered. The extracts were evaporated } \\
\text { under reduced pressure and redissolved in } \\
\text { methanol at a concentration of } 20 \mathrm{mg} / \mathrm{mL} \text {. }\end{array}$ & {$[171]$} \\
\hline $\begin{array}{l}\text { Aspergillus wentii, A. wentii, } \\
\text { Penicillium citrinum, } \\
\text { Penicillium granulatum }\end{array}$ & $\begin{array}{l}\text { DPPH, FRAP, } \\
\text { MCA/ferrous ion, } \\
\text { NO^ scavenging } \\
\text { activity, RP/potassium } \\
\text { ferricyanide }\end{array}$ & $\begin{array}{l}\text { ascorbic acid, BHT, } \\
\text { rutin, catechin }\end{array}$ & $\begin{array}{l}\text { The fungal mycelia were grown on agar plates } \\
\text { with extracts of yeast and glucose. After } 6 \text { to } \\
7 \text { days, the Czapek-Dox's broth was inoculated } \\
\text { of fungal mycelia. After } 10 \text { days of incubation } \\
\text { at } 25^{\circ} \mathrm{C} \text {, the culture broth was filtered. }\end{array}$ & [289] \\
\hline $\begin{array}{l}\text { Aspergillus niger, } \\
\text { Aspergillus peyronelii }\end{array}$ & $\begin{array}{l}\mathrm{DPPH}, \mathrm{RP} \\
\mathrm{H}_{2} \mathrm{O}_{2} \text { scavenging } \\
\text { activity }\end{array}$ & ascorbic acid & $\begin{array}{l}\text { The dried samples were extracted by the use of } \\
\text { ethyl acetate }(1: 10) \text { applying cold percolation } \\
\text { for } 48-72 \mathrm{~h} \text {. Then, obtained extracts were } \\
\text { filtered, and concentrated under vacuum at } \\
40^{\circ} \mathrm{C} \text {. }\end{array}$ & {$[290]$} \\
\hline Aspergillus versicolor & ABTS, DPPH & Trolox & $\begin{array}{l}\text { Aspergillus versicolor was cultivated on rice } \\
\text { for } 30 \text { days. The EtOAc extracts of solid } \\
\text { fermentation were fractioned through slica gel } \\
\text { and Sephadex LH-20 column chromatography } \\
\text { (CC), and were further purified by } \\
\text { semi-preparative HPLC. }\end{array}$ & [291] \\
\hline
\end{tabular}


Table 3. Cont.

\begin{tabular}{|c|c|c|c|c|}
\hline Analysed Product & $\begin{array}{l}\text { Antioxidant } \\
\text { Assays }\end{array}$ & $\begin{array}{l}\text { Positive } \\
\text { Control } \\
\end{array}$ & Extraction Procedure & Ref. \\
\hline Auricularia auricular & $\begin{array}{l}\text { ABTS, } \mathrm{O}_{2}^{\bullet-}, \mathrm{OH}^{\bullet} \\
\text { scavenging activity, } \\
\text { lipid peroxidation }\end{array}$ & - & $\begin{array}{l}\text { A.auricula was extracted by hot water and } \\
\text { ultrasonic-assisted extraction. The supernatants } \\
\text { were precipitated with absolute ethanol }(95 \%) \\
\text { and maintained at } 4{ }^{\circ} \mathrm{C} \text { overnight. The } \\
\text { precipitate was centrifugated, dissolved in DI, } \\
\text { and dialyzed. The non-dialyzed portion was } \\
\text { lyophilized to give a crude polysaccharide } \\
\text { extract. The separation of polysaccharides was } \\
\text { performed using CTAB or CPC. }\end{array}$ & [292] \\
\hline Cephalosporium sp. & DPPH & gallic acid & $\begin{array}{l}\text { The fermented material }(1.75 \mathrm{~kg}) \text { was extracted } \\
\text { twice with EtOAc }(9.0 \mathrm{~L}) \text { for } 3 \text { days at RT, and } \\
\text { the extract was evaporated under vacuum. }\end{array}$ & [293] \\
\hline Cerrena unicolor & ABTS, DPPH & Trolox, ascorbic acid & $\begin{array}{l}\text { Ten-day-old cultures were filtered and washed } \\
\text { with DW. The fungal biomass was used for the } \\
\text { polysaccharides extraction by hot water }\left(90^{\circ} \mathrm{C} \text {, }\right. \\
4 \mathrm{~h}) \text {. The proteins were separated by anion } \\
\text { exchange chromatography on a DEAE } \\
\text { Sepharose column with a linear gradient of } \\
\mathrm{NaCl}(0.1-0.5 \mathrm{M}) \text {. The culture liquid was } \\
\text { subdivided into two fractions by ultrafiltration: } \\
\text { substances above } 10 \mathrm{kDa} \text { (rude lactase) and } \\
\text { substances below } 10 \mathrm{kDa} \text { with low molecular } \\
\text { weight metabolites. }\end{array}$ & [294] \\
\hline $\begin{array}{l}\text { Flammulina velutipes, } \\
\text { Hypsizygus tessellatus }\end{array}$ & $\begin{array}{l}\text { DPPH, } \mathrm{H}_{2} \mathrm{O}_{2} \\
\text { scavenging activity, } \\
\text { FRAP }\end{array}$ & gallic acid, quercetin & $\begin{array}{l}\text { The stems of the mushrooms were dried at } \\
60^{\circ} \mathrm{C} \text { and pulverized. Samples }(180 \mathrm{~g}) \text { were } \\
\text { extracted overnight with } 500 \mathrm{~mL} \text { of water, } \\
\text { absolute methanol, } 95 \% \text { acetone, or } 95 \% \text { ethyl } \\
\text { acetate at RT. The extracts were filtered, } \\
\text { evaporated to dryness. Aqueous fractions were } \\
\text { concentrated to } 50 \mathrm{~mL} \text {, freeze-dried, and stored } \\
\text { at } 4{ }^{\circ} \mathrm{C} \text {. }\end{array}$ & [295] \\
\hline
\end{tabular}

$\mathrm{DPPH}, \beta$-carotene bleaching assay,

Grifola frondosa inhibition of lipid peroxidation, RP, CUPRAC

DPPH, RP, FRAP

Penicillium expansum

$\mathrm{MCA} /$ ferrous ion, $\mathrm{NO}^{\circ}$ scavenging activity
Mushrooms were boiled in DW at the ratio of $1: 10(w / v)$ for $30 \mathrm{~min}$. Then, the extract was filtered, and freeze-dried.

The fungi were grown on CDM, MEM, PDM and YEM. After incubation at $25^{\circ} \mathrm{C}$ for 10 days, the culture broth was filtered through filter paper. The culture broth was extracted with petroleum ether, chloroform, ethyl acetate, and butanol. Then, the extracts were then evaporated to dryness in a vacuum, and the precipitates were dissolved in DMSO.

Five grams of dried wheat straw was ground, washed, and dried at $90^{\circ} \mathrm{C}$. Next, it was moistened by the use of $25 \mathrm{~mL}$ of malt extract $(0.5 \%, w / v)$ and inoculated with three mycelial discs $(8 \mathrm{~mm})$, which were grown on YGA plates for 6 days. The inoculated flasks were kept at $25{ }^{\circ} \mathrm{C}$ for 30 days. Then, they were homogenized, filtered, and dried at $90^{\circ} \mathrm{C}$.

Phlebia brevispora,

Phlebia radiate,

Phlebia fascicularia
DPPH, FRAP,

scavenging activity 
Table 3. Cont.

\begin{tabular}{|c|c|c|c|c|}
\hline Analysed Product & $\begin{array}{l}\text { Antioxidant } \\
\text { Assays }\end{array}$ & $\begin{array}{l}\text { Positive } \\
\text { Control }\end{array}$ & Extraction Procedure & Ref. \\
\hline $\begin{array}{l}\text { Pleurotus florida, } \\
\text { Pleurotus sajor-caju, } \\
\text { Pleurotus cystidiosus, } \\
\text { Pleurotus djamor }\end{array}$ & $\begin{array}{l}\text { FRAP, } \mathrm{DPPH}, \mathrm{RP}, \\
\mathrm{MCA}, \mathrm{H}_{2} \mathrm{O}_{2} \text {, } \\
\mathrm{O}_{2}{ }^{\bullet-} \text { scavenging } \\
\text { activity }\end{array}$ & - & $\begin{array}{l}\text { Sporophores were cleaned and dried at } \\
40 \pm 2{ }^{\circ} \mathrm{C} \text { for } 10-12 \mathrm{~h} \text {. The obtained powders } \\
(100 \mathrm{~g}) \text { were refluxing with light petrol } \\
\left(60-80^{\circ} \mathrm{C}\right) \text { for } 6 \mathrm{~h} \text { with the aim of defatting. } \\
\text { Then, the material was extracted with } 95 \% \\
\text { ethanol }(500 \mathrm{~mL} \times 3) \text { by refluxing for } 6 \mathrm{~h} \text {. The } \\
\text { extracts were combined, filtered, and } \\
\text { evaporated to dryness at } 40^{\circ} \mathrm{C} \text {. The dried } \\
\text { extracts were redissolved in methanol at a } \\
\text { concentration of } 20 \mathrm{mg} / \mathrm{mL} \text { for analysis. }\end{array}$ & [299] \\
\hline $\begin{array}{l}\text { Trametes versicolor, } \\
\text { Trametes hirsuta, } \\
\text { Trametes gibbosa }\end{array}$ & ABTS, FRAP & ascorbic acid & $\begin{array}{l}\text { Dried material }(3.0 \mathrm{~g}) \text { was grounded. } \\
\text { Extraction was carried out in } 96 \% \text { ethanol } \\
\text { during } 72 \mathrm{~h} \text {. The extracts were centrifuged and } \\
\text { supernatants filtrated. The filtrates were } \\
\text { concentrated under reduced pressure at } 40^{\circ} \mathrm{C} \\
\text { to dryness and redissolved in } 96 \% \text { ethanol }\end{array}$ & [300] \\
\hline
\end{tabular}

Bacteria

$\beta$-carotene-linoleate,

Bacillus coagulans RK-02

\section{$\mathrm{O}_{2}{ }^{\bullet-}, \mathrm{OH}^{\bullet}$}

scavenging

activity, DPPH ascorbic acid $\alpha$-tocopherol

to dryness and redissolved in $96 \%$ ethanol

Sporophores were cleaned and dried at

$\pm 2{ }^{\circ} \mathrm{C}$ for $10-12 \mathrm{~h}$. The obtained powders

$\left(60-80{ }^{\circ} \mathrm{C}\right)$ for $6 \mathrm{~h}$ with the aim of defatting. for $6 \mathrm{~h}$. The extracts were combined, filtered, and concentration of $20 \mathrm{mg} / \mathrm{mL}$ for analysis.

The $36 \mathrm{~h}$ culture was centrifuged at $10,000 \times g$ for $20 \mathrm{~min}$ at RT. The supernatant was filtered. The proteins were isolated by the addition of $10 \%$ TCA. After $12 \mathrm{~h}$ at $4{ }^{\circ} \mathrm{C}$, the mixture was centrifugated. Four volumes of $95 \%$ ethanol were added to the supernatant and centrifuged. The pellet was lyophilized, dissolved in $5 \mathrm{~mL}$ DW and dialyzed (MWCO 12,000 Da).

The cultures were heated at $100^{\circ} \mathrm{C}$ for $10 \mathrm{~min}$. The cells were removed by centrifugation at $12,000 \times g$ for $15 \mathrm{~min}$ at $4{ }^{\circ} \mathrm{C}$. The supernatant was precipitated with double volume of chilled ethanol, shaken, and centrifuged at $985000 \times g$

Weissella cibaria GA44 $\mathrm{DPPH}, \mathrm{RP}, \mathrm{O}_{2}{ }^{\bullet-}, \mathrm{OH}^{\bullet}$ scavenging activity ascorbic acid $\mathrm{H}_{2} \mathrm{O}_{2}{ }^{-}$induced oxidative stress in Caco-2 cells $50{ }^{\circ} \mathrm{C}$, and dissolved in wat $50^{\circ} \mathrm{C}$, and dissolved in water. This step wa distilled water for two days at $4{ }^{\circ} \mathrm{C}$ using $10 \mathrm{kDa}$ dialysis membrane and then lyophilized.

After $20 \mathrm{~h}$ of the incubation period, TCA was added to achieve $4 \%(w / v)$. The mixture was stirred for $30 \mathrm{~min}$ at RT. Cells were removed by centrifugation $\left(10,000 \times \mathrm{g}, 4^{\circ} \mathrm{C}, 15 \mathrm{~min}\right)$. Crude EPS was precipitated by the addition of 2 volumes of cold ethanol. Crude EPS was collected by centrifugation. The pellet was dissolved in deionized water and dialyzed (MW cut-off $3500 \mathrm{Da}$ ) for $24 \mathrm{~h}$ against distilled water at $4{ }^{\circ} \mathrm{C}$ and then lyophilized.

The bacteria were cultured in $500 \mathrm{~mL}$ broth at $35^{\circ} \mathrm{C}$. Then, the culture was centrifuged at $8000 \times g$ for $5 \mathrm{~min}$. The supernatant was

Pseudomonas hibiscicola,

Macrococcus caseolyticus,

Enterobacter ludwigii,

$\mathrm{DPPH}$

ascorbic acid extracted with ethyl acetate (ratio of 1:1). Then the extract was concentrated to dryness in a rotatory evaporator at $37^{\circ} \mathrm{C}$. The solids were re-dissolved in $20 \%$ DMSO and filtered.

Isolated bacteria were cultured in $500 \mathrm{~mL}$ of

Alteromonas sp

Shewanella sp.

Serratia sp.,

Citricoccus sp.,

DPPH, ORAC

BHT, Trolox Marine Broth for 3 days at $25^{\circ} \mathrm{C}$. Bacteria cells were centrifuged, and the pellet was lyophilized. Then, the lyophilizes were extracted with methanol and dichloromethane

Cellulophaga sp.,

(1:1) for $12 \mathrm{~h}$. The solvents were evaporated at

Ruegeria sp.

Staphylococcus sp. in DMSO. 
Table 3. Cont

\begin{tabular}{llcl}
\hline \multicolumn{1}{c}{ Analysed Product } & \multicolumn{1}{c}{$\begin{array}{c}\text { Antioxidant } \\
\text { Assays }\end{array}$} & $\begin{array}{c}\text { Positive } \\
\text { Control }\end{array}$ & Extraction Procedure \\
\hline $\begin{array}{l}\text { Pseudomonas sp. } \\
\text { (HR04) }\end{array}$ & $\begin{array}{l}\text { anti-lipoperoxidative } \\
\text { activity }\end{array}$ & BHT, $\alpha$-tocopherol & $\begin{array}{l}\text { The mycelial cake was extracted with acetone } \\
\text { followed by purification by column } \\
\text { chromatography on silica gel and } \\
\text { Sephadex L }\end{array}$
\end{tabular}

Sephadex LH-20.

An aliquot $(10 \mathrm{~mL})$ of bacteria suspended in

LPO, ABTS,

Lactobacillus casei

CRL 431 (IC431)

ORAC

CAT, GPx

Trolox PBS was mixed with lysozyme $(1 \mathrm{mg} / \mathrm{mL})$ and incubated at $37^{\circ} \mathrm{C}$ for $150 \mathrm{~min}$. Then, cells were disrupted by sonication in an ultrasonic processor at $10{ }^{\circ} \mathrm{C}$. After centrifugation $\left(3600 \times g, 4^{\circ} \mathrm{C}, 10 \mathrm{~min}\right)$, the supernatant was collected and stored in dark at $4{ }^{\circ} \mathrm{C}$.

The cells were washed with $0.85 \% \mathrm{NaCl}$ and sonicated. The obtained fluid was mixed with $75 \%$ ethanol. The precipitate was collected, redissolved, deproteinized, purified on an

Lactobacillus fermentum

DPPH, ABTS, FRAP, $\mathrm{OH}^{\bullet}$ scavenging activity

ascorbic acid anion exchange column eluting with deionized water, $0.1 \mathrm{M}$, and $0.3 \mathrm{M} \mathrm{NaCl}$ and subsequently loaded onto a Sephadex G-100 column and eluted with DW. The collected fractions were lyophilized.

A total of $5 \mathrm{~mL}$ of crude EPS solution

$(20 \mathrm{mg} / \mathrm{mL})$ was separated with

DEAE-cellulose column using deionized water, 0.2 and $0.5 \mathrm{M} \mathrm{NaCl}$ as eluent. Peak fractions containing polysaccharides were pooled, dialyzed, and lyophilized. Then, the fraction was further purified on a Sepharose CL-6B gel column and eluted with $0.9 \mathrm{M} \mathrm{NaCl}$ solution.

The cultures were centrifugated at $5000 \times g$ at $4{ }^{\circ} \mathrm{C}$ for $15 \mathrm{~min}$. The supernatant was added to 0.4 TCA at $4{ }^{\circ} \mathrm{C}$ for $3 \mathrm{~h}$. Then, the supernatant (101EP),

Lactobacillus plantarum

DPPH, MCA/ferrous

acid

peroxidation, $\mathrm{RP}$ was mixed with ethanol at $4{ }^{\circ} \mathrm{C}$ for $24 \mathrm{~h}$, followed by centrifugation. The obtained

ascorbic acid precipitate was dialyzed for $24 \mathrm{~h}$ and lyophilized.

\begin{tabular}{|c|c|c|c|c|}
\hline \multicolumn{5}{|c|}{ Algae } \\
\hline Astaxanthin & $\begin{array}{l}\text { FRAP, TEAC } \\
\text { ORAC, DPPH }\end{array}$ & tert-Butyl alcohol & $\begin{array}{l}\text { Astaxanthin was dissolved in } \\
\text { tetrahydrofuran (THF). }\end{array}$ & [244] \\
\hline $\begin{array}{l}\text { Desmarestia antarctica, } \\
\text { Iridaea cordata }\end{array}$ & RP, TPC, DPPH & gallic acid, ascorbic acid & $\begin{array}{l}\text { The samples were rinsed with Milli-Q water, } \\
\text { cut into fine pieces, then boiled at reflux for } \\
15 \text { min. The flask was moved to an ice bath to } \\
\text { complete the extraction. The extract was thus } \\
\text { centrifuged at } 4500 \mathrm{rpm} \text { for } 10 \mathrm{~min} \text {, and the } \\
\text { supernatant was filtered and stored at } 4{ }^{\circ} \mathrm{C} \text {. }\end{array}$ & [310] \\
\hline $\begin{array}{l}\text { Haematococcus pluvialis, } \\
\text { synthetic astaxanthin }\end{array}$ & ABTS, ORAC, CAA & Trolox & $\begin{array}{l}\text { The extracts were obtained by solvent using } \\
\text { DMSO or supercritical extraction }\left(\mathrm{AstaCO}_{2}\right) \text {. }\end{array}$ & [311] \\
\hline astaxanthin & ORAC-EPR & - & $\begin{array}{l}\text { The acetonitrile solutions of Catechin, } \\
\text { epicatechin, epigallocatechin gallate, } \\
\text { kaempferol, myricetin, resveratrol, and } \\
\text { astaxanthin were diluted with phosphate buffer } \\
\text { containing DM- } \beta \text {-CD. }\end{array}$ & [312] \\
\hline $\begin{array}{l}\text { Dunaliella salina, } \\
\text { Tetraselmis chuii, } \\
\text { Isochrysis galbana } \\
\text { clone Tahiti. }\end{array}$ & DPPH & - & $\begin{array}{l}\text { Methanolic extracts were prepared in different } \\
\text { concentrations }(50,100,250,500 \text {, and } \\
1000 \text { ppm). }\end{array}$ & [313] \\
\hline
\end{tabular}


Table 3. Cont

\begin{tabular}{ccc}
\hline Analysed Product & $\begin{array}{c}\text { Antioxidant } \\
\text { Assays }\end{array}$ & Positive \\
& Control \\
\hline
\end{tabular}

Galderia sulphuraria,

Neochloris texensis,

Stichococcus bacillaris,

Ettlia carotinosa,

Chlorella minutissima,

Schizochytrium limacinum,

Crypthecodinium cohnii,

Chlorella vulgaris
$\mathrm{DPPH}$

$\begin{array}{lll}\text { Chlorella vulgaris } & \text { ORAC, DPPH, FRAP } & \text { Trolox } \\ \text { Spirulina platensis } & \end{array}$

Extraction Procedure

Ref.

Methanol extraction: $20 \mathrm{~mL}$ methanol was added to $0.5 \mathrm{~g}$ dry biomass and sonicated ( 9 cycles, $50 \%$ power) for $20 \mathrm{~min}$. Then, samples were centrifuged at $3500 \mathrm{rpm}$ for $5 \mathrm{~min}$. Pellets were re-extracted in $20 \mathrm{~mL}$ methanol 3 times and the supernatants were collected. The samples were filtered and evaporated at $40{ }^{\circ} \mathrm{C}$. Hot water extraction: $1 \mathrm{~g}$ of dry sample was added to $100 \mathrm{~mL}$ DW and boiled for $30 \mathrm{~min}$. After cooling, extracts were centrifuged at $3500 \mathrm{rpm}$ for $10 \mathrm{~min}$, and supernatants were freeze-dried.

The extracts were obtained by the use of ultrasound-assisted extraction by water/ethanol $(50: 50, v / v)$.

Different solvents such as ethanol, methanol, butanol, acetone, DMSO, and water were used for extraction. One gram of dried samples were mixed with $10 \mathrm{~mL}$ for each solvent. The extraction was carried out for $30 \mathrm{~min}$ by sonication $(40 \mathrm{kHz})$ in an ultrasonic bath followed by a $2 \mathrm{~h}$ shake, and centrifugation for $10 \mathrm{~min}$.

A total of $100 \mathrm{mg}$ of freeze-dried biomass was extracted with $1 \mathrm{~mL}$ ethanol/water $(3: 1, v / v)$ for $30 \mathrm{~min}$. The mixture was centrifuged at $4500 \times g$, for $10 \mathrm{~min}$, at $20^{\circ} \mathrm{C}$. Then, the ethanolic phase was dried.

$\begin{array}{ccc}\text { Tetraselmis suecica } & \text { DPPH } & \alpha \text {-tocopherol }\end{array}$

\section{Lichens}

$\mathrm{DPPH}$, the thiocyanate method, $\mathrm{RP}, \mathrm{O}_{2}{ }^{\bullet}$ scavenging activity $\alpha$-tocopherol, BHT, BHA

For water extraction, $20 \mathrm{~g}$ sample was mixed with $400 \mathrm{~mL}$ boiled DW and stirred for $15 \mathrm{~min}$. Then, the extract was filtered. The obtained filtrates were frozen and lyophilized.

Cell mass (14.8 g dry wt) was extracted using $20 \mathrm{~mL}$ of $10 \%(v / v)$ acetone, dimethyl sulphoxide (DMSO), methanol or light petroleum $\left(40-60{ }^{\circ} \mathrm{C}\right)$ at RT. The extracts were then filtered, concentrated 4 -fold under activity, lipid peroxidation/linoleic quercetin vacuum, and freeze-dried and then dissolved in $1 \mathrm{~mL}$ of acetone, DMSO, methanol, or water for the preparation of test stock solutions.

Air-dried and powdered lichens ( $10 \mathrm{~g}$ ) were mixed with $250 \mathrm{~mL}$ of methanol. The extraction was conducted in the Soxhlet apparatus for $72 \mathrm{~h}$ at a temperature of the boiling point of the

DPPH, the inhibition of linoleic acid oxidation gallic acid

Umbilicaria nylanderiana solvent. The extracts were filtered and then concentrated in vacuo at $40{ }^{\circ} \mathrm{C}$.

One hundred grams of pulverized dried lichen were extracted with $1 \mathrm{~L}$ of methanol using a Soxhlet apparatus for $72 \mathrm{~h}$. The obtained extracts were filtered and then concentrated under reduced pressure.

Powdered lichen samples $(250 \mathrm{~g})$ were subjected to soxhlet extraction using acetone and methanol. The extracts were then filtered through filter paper, concentrated in vacuo, and air-dried.
Anaptychya ciliaris,

Parmelia centrifuga

Parmotrema praesorediosum,

P. rampoddense,

P. tinctorum

DPPH

P. reticulatum
$\mathrm{MCA} /$ ferrous ion, reagent, $R P$
Trolox, ascorbic acid

Actinomycetes

$\begin{array}{lll}\text { Streptomyces } & \text { DPPH } & \alpha \text {-tocopherol } \\ (\text { R56-07) } & \end{array}$

The ethyl acetate extract of the fermentation broth was subjected to silica gel MPLC and for further purification to a Sephadex LH-20 column and RP-HPLC. 
Table 3. Cont.

\begin{tabular}{|c|c|c|c|c|}
\hline Analysed Product & $\begin{array}{l}\text { Antioxidant } \\
\text { Assays }\end{array}$ & $\begin{array}{l}\text { Positive } \\
\text { Control }\end{array}$ & Extraction Procedure & Ref. \\
\hline Streptomyces chromofuscus & $\begin{array}{l}\text { the inhibition of lipid } \\
\text { peroxidation, DPPH }\end{array}$ & $\alpha$-tocopherol BHT & $\begin{array}{l}\text { Carbazole compounds, carazostatin, } \\
\text { carbazomycin B and their chemically modified } \\
\text { derivatives were isolated from the culture of } \\
\text { Streptomyces chromofuscus by the use of } \\
\text { chromatography on silica gel with } \\
\text { hexane-EtOAc (20:1) as an eluent. }\end{array}$ & [318] \\
\hline Streptomyces sp. (CL190) & $\begin{array}{l}\text { the inhibition of } \\
\text { lipid peroxidation }\end{array}$ & $\alpha$-tocopherol & $\begin{array}{l}\text { The mycelial cake was stirred with acetone. } \\
\text { The extract was concentrated in vacuo and } \\
\text { extracted twice with ethyl acetate. The extract } \\
\text { was dried and concentrated in vacuo. The } \\
\text { fraction was applied to a silica gel column with } \\
\text { n-hexane and ethyl acetate }(4: 1) \text {. The fraction } \\
\text { was concentrated to dryness. The dry residue } \\
\text { was rechromatographed on a silica gel column } \\
\text { with chloroform, methanol, and ammonia } \\
\text { (200:20:1). The elute was concentrated in vacuo } \\
\text { and the residue was dissolved in chloroform } \\
\text { and methanol (1:1) and purified by column } \\
\text { chromatography on Sephadex LH-20 with the } \\
\text { same mixture. The fraction was evaporated to } \\
\text { dryness in vacuo and dissolved in ethyl acetate. }\end{array}$ & [319] \\
\hline $\begin{array}{l}\text { Streptomyces LK-3 } \\
\text { (JF710608) }\end{array}$ & $\begin{array}{l}\mathrm{DPPH}, \mathrm{MCA} / \text { ferrous } \\
\text { ion, FRAP, } \beta \text {-carotene } \\
\text { assay, } \mathrm{NO}^{\bullet} \\
\text { scavenging activity }\end{array}$ & gallic acid & $\begin{array}{l}\text { The crude extracts were diluted in water } \\
\text { containing daidzein- } 8 \text {-C-glucoside (puerarin), } \\
\text { (-) gallocatechin gallate, sesamol, } \\
\text { cyanidin-3-O-rutinoside, and delphinidinas. }\end{array}$ & [320] \\
\hline
\end{tabular}

Abbreviations: DPPH (2,2-diphenyl-1-picrylhydrazyl), CUPRAC (cupric reducing antioxidant capacity), FRAP (ferric reducing ability of plasma), TEAC (Trolox equivalent antioxidant capacity), EPR (electron paramagnetic resonance method), SNPAC (silver nanoparticles antioxidant capacity), BHT (butyl-hydroxytoluene), TE (Trolox equivalents), RP (reducing power assay), TPC (Total Phenolic Content), MCA (metal chelating activity assays), TBARS (Thiobarbituric Acid Reactive Substances), AAP (A. auricula-judae polysaccharide), EPS (Exopolysaccharide), SDM (A semi-defined medium), LPO (lipid peroxidation-hepatic lipid peroxidation), CAT (Antioxidant Enzymes Activity-catalase), GPx (glutathione peroxidase), TCA (trichloroacetic acid), ESR (electron spin resonance), XO (xanthine oxidase), GR (glutathione reductase), PMSF (phenylmethanesulfonylfluoride), CAA (cellular antioxidant activity), RT (room temperature), GSH (Reduced glutathione), CTAB (Cetyl Trimethyl Ammonium Bromide), CPC (Cetylpyridinium Chloride), CDM (Czapek Dox's Medium), MEM (Malt Extract Medium), PDM (Potato Dextrose Medium), YEM (yeast extract glucose medium), YGA (yeast extract glucose agar), Astaxanthin (3,31-dihydroxy- $\beta, \beta$ 1-carotene-4,41-dione), DMSO (dimethyl sulfoxide).

\section{Synthesis of Nanoparticles (NPs) by Natural Extracts}

The various types of metallic/metal oxides nanoparticles composed of silver, gold, platinum, palladium, cerium, copper, nickel, selenium, or iron have been described in the literature. Their unique physicochemical properties make them advanced materials for industry and biomedical applications [321]. There is also evidence that, besides natural extracts, some nanoparticles such as carbon nanotubes, metal, and metal oxides, and various types of polymer-loaded nanoparticles also possess antioxidant activity and can scavenge the reactive nitrogen and reactive oxygen species (RNS/ROS) [322,323]. The iron nanoparticles (INPs), due to high catalytic activity, low toxicity, high magnetism, and microwave absorption ability [324-326], have already found varied applications in pharmacy (drug delivery), clinical diagnostic (magnetic targeting, negative MRI contrast enhancement, pigments, stem cell sorting), therapy (gene therapy), and analytical chemistry (bio-separation), bioprocesses (environmental remediation, food preservation), industry (lithium-ion batteries) [247,327].

Unfortunately, nanoparticles synthesized by chemical methods often require toxic reducing and stabilizing agents. These toxic substances adsorbed on the surfaces of the nanoparticles limit their applications in biomedical fields [143]. Thus to obtain nanomaterials, the natural synthesis methods involving the reduction of metallic cations by plant extracts, yeasts, fungus, and bacteria are used more and more often. The formation of NPs is achieved via two steps: in the first one, metal ions are reduced, and in the second one the agglomeration of colloidal suspension causing the formation of the oligomeric clusters [328]. So-called "green synthesis" or "biogenic synthesis" has gained more and 
more attention as an eco-friendly approach useful for synthesis of not only metal/metal oxide nanoparticles but also the production of other nanomaterials, such as hybrid materials, or a variety of bioinspired materials. Nanoparticles produced by green synthesis methods may be less stable compared to nanoparticles obtained as a product of chemical synthesis [329-331]. The stabilization of nanoparticles is mainly achieved by electrostatic repulsion. Unfortunately, this type of stabilization is only effective with low ionic strength extracts where the repulsion is facilitated by the highly dispersed double layer. In the case of high ionic strength, aggregation occurs under the influence of strong van der Waals interactions [332]. Another type of stabilization is the creation of an additional barrier on the surface of the NPs. Steric stabilization is provided by proteins, if they are components of the extracts, or by coating the surface with polymers such as PEG or PVP (polyethylene glycol, polyvinylpyrrolidone). Steric stoppers, thanks to their hydrophilic properties, provide an additional stabilizing element in the form of short-distance repulsive forces. The stages of NPs formation and stabilization are schematically illustrated in Figure 7.

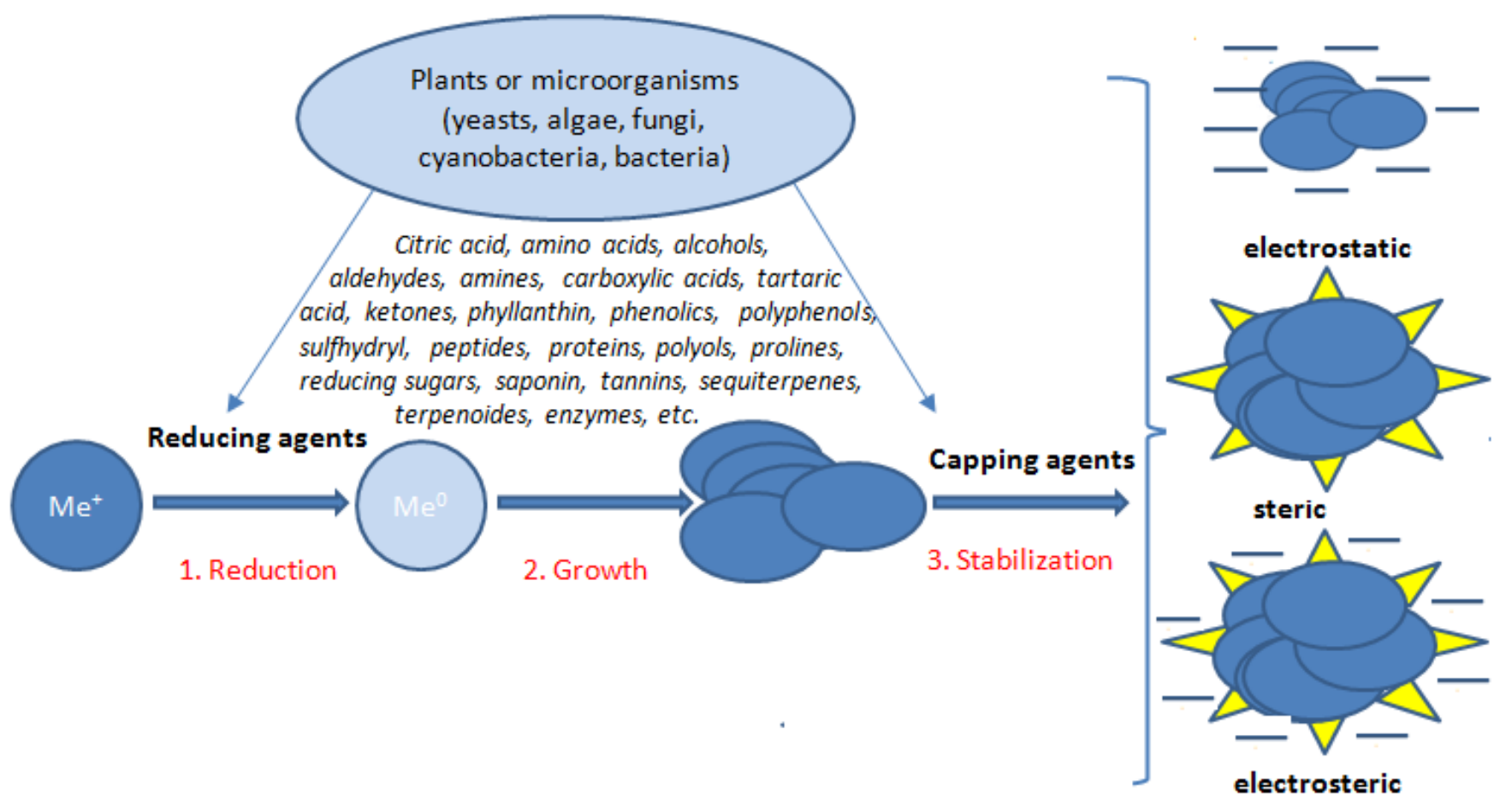

Figure 7. Schematic diagram illustrating the mechanisms of the biogenic synthesis of metallic nanoparticles.

Presently, one can observe an increasing interest in studies on the reactivity of nanoparticles compared to macroscopic objects and their cytotoxicity [333-337] accumulation in the body, which can generate reactive oxygen species (ROS) [338-341]. A relatively new area of research is the use of nanoparticles with redox-active potential as radical scavengers. For example, cerium and yttrium oxides either act as antioxidants [342] or can prevent the increase of ROS [343,344] by mimicking the activity of the oxidative enzymes, catalase, or superoxide dismutase [345]. It has been proven that silver nanoparticles (AgNPs) inhibit cell proliferation and modulate the activity of antioxidant enzymes [340,346,347]. Hirst et al. confirmed by an in vivo test on mice the effectiveness of cerium oxide nanoparticles (CONPs) in treating oxidative stress [348]. A comparative study conducted by Caputo et al. (2015) revealed that the antioxidant potential of N-acetyl-cysteine and Trolox (soluble analogues of vitamin E) was significantly lower in comparison to CONPs [349]. The authors highlighted the CONPs regenerative redox cycle influencing the stability of the antioxidants molecules. 


\subsection{Microbial Synthesis of NPS}

The first experiments on AgNPs biosynthesis using bacteria were carried out in the culture of Pseudomonas stutzeri AG 259, Morganella sp. Bacillus subtilis [350]. Using microscopic and spectral techniques SEM, TEM, EDX, and EDS, it was possible to identify various shapes of nanoparticles, i.e., triangular, hexagonal, and spherical with sizes ranging from a few to several hundred $\mathrm{nm}$. The synthesis process was initiated within the first hour of cultivation. The obtained NPs were coated with protein, which allowed them to maintain stability and avoid their aggregation. It has been shown that the enzyme nitrate reductase is responsible for the reduction of silver ions. Thus far, the participation of other groups of enzymes, whose role is electron donation and their further transfer, has been described and proven, i.e., nitrate and iron reductases, dependent on the nicotinamide adenine dinucleotide (NAD+)/NADH and the nicotinamide adenine dinucleotide phosphate NADP+/NADPH redox couples hydrogenase, and oxidase. Silver ions, due to their interaction with cytochromes and inhibition of electron transport, lead to disturbances in the functioning of the respiratory chain. The mechanism of silver nanoparticle synthesis in lactic acid bacteria was investigated in detail [351]. It was noted that the alkaline environment clearly favors the formation of nanoparticles as it catalyzes the enolization of monosaccharides. The resulting aldehyde is oxidized to carboxylic acid, while the metal ions are reduced to nanoparticles.

The effect of nanoparticles on bacteria is complex and not fully understood due to the existence of numerous mechanisms of action (Figure 8). Bacteria and other microorganisms such as viruses, fungi, flagella, yeasts, and actinomycetes possess the ability to produce metallic NPs intracellularly as well as extracellularly. The studies showed the action of AgNPs on Escherichia coli and Staphylococcus ureus [352]. The appearance of pits in the bacterial envelope has been observed, which lead to a change in the electrostatic potential, an increase in the permeability of membranes, and damage to the DNA of the cell. Later, research was extended to other species of bacteria, which allowed for the emergence of two more mechanisms of action in the form of overproduction of free radicals (ROS) and the formation of complexes with various intracellular compounds, i.e., nucleic acids [353,354]. It is particularly interesting that even a short incubation with nanoparticles leads to the accumulation of chaperones and the S6 protein [355] and inhibition of the bacterial communication system (quorum sensing, QS), which is associated with a change in gene expression controlled by transcription regulators. It is known that disturbances in the functioning of these genes cause a change in the behavior of cells in the environment, e.g., the ability to create biofilms. This applies even to pathogenic bacterial strains such as Pseudomonas aeruginosa and Staphylococcus aureus. Biofilms create populations of microorganisms (bacteria, fungi, protozoa) that live at the interface [356]. They are surrounded by a protective substance composed of polysaccharides, proteins and nucleic acids, called a matrix. Biofilm formation is a multi-step process but is always initiated by adhesion. Within the biofilm, there may be synergistic or antagonistic interactions between the species inhabiting it, which may lead to the matrix disintegration [357]. The most dangerous are biofilms composed of pathogenic bacteria E. faecalis, S. aureus, Staphylococcus epidermidis, E. coli, Klebsiella pneumoniae, and P. aeruginosa [358], which are mostly responsible for hospital infections that are difficult to cure and are characterized by increased resistance to therapies [359]. The antibiotic resistance of biophimes is the result of, among other things, the presence of a matrix that is a barrier to drug penetration and the production of enzymes responsible for the hydrolysis of $\beta$-lactam antibiotics [360,361]. Research on the potential of nanoparticles to combat biofilms meets the expectations of modern medicine. However, the number of publications on this topic has so far been rather small. It was shown that P. aeruginosa and S. epidermidis biofilms were inhibited in over $95 \%$ of cases by silver nanoparticles with a spherical shape and an average diameter of $50 \mathrm{~nm}$ [362]. The inhibition of biofilms formed by Multidrug-Resistant Klebsiella pneumoniae [363], Methicillin-Resistant Staphylococcus aureus [364], and Mycobacterium tuberculosis [365] has been proven. Unfortunately, the aggregation of nanoparticles inhibits their effective activity. Consequently, various stabiliz- 
ers such as starch, citrate, and amino silica are used, and numerous composites composed of nanoparticles and other compounds have been identified. There are also reports on the inhibition of biofilm formation by AgNPs on medical devices, i.e., urological catheters, the surface of which was covered with nanosilver, were characterized by resistance to E. coli, S. aureus, and Candida albicans, even under continuous fluid flow conditions. [366]. Metallic/metal oxide nanoparticles, i.e., silver, gold, magnesium, titanium, zinc, aluminum, tantalum, and zirconium have been tested in orthopedics [367-370]. Nanoparticles embedded in implants and orthopedic scaffolds provide mechanical strength and antimicrobial protection. However, it should be remembered that many nanoparticles exhibit cytotoxicity and genotoxicity, especially in the case of their small size and higher concentrations [371].

\section{Mechanism of antibacterial activity}

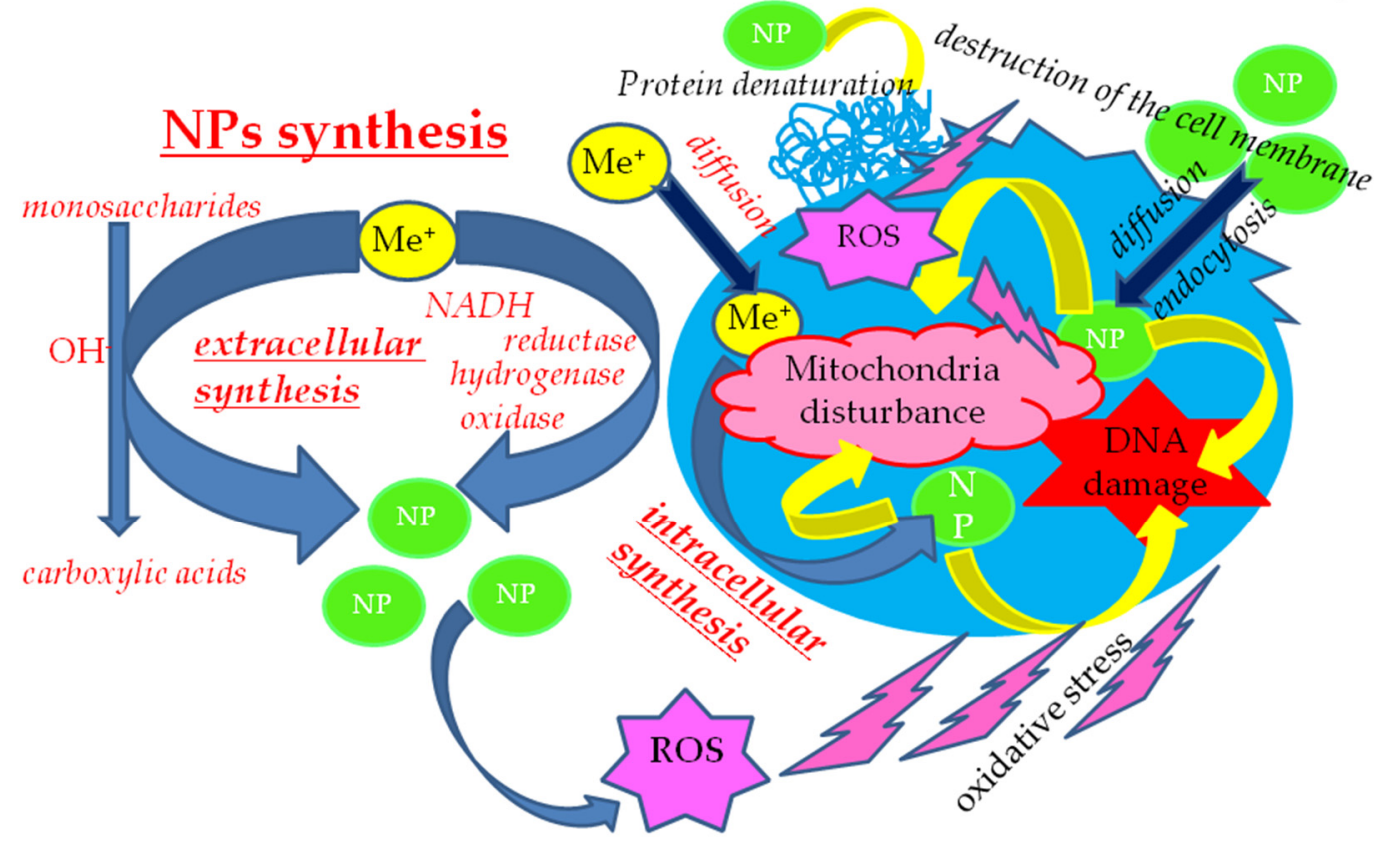

Figure 8. Schematic representation of intra- and extracellular NPs synthesis together with their possible mechanisms of antibacterial action.

Interesting examples of NPs that were produced by microorganisms are iron oxide nanoparticles which were produced by aquatic magnetotactic bacteria (MTB). These bacteria are able to biomineralize, magnetic magnetite, or greigite nanocrystallites called magnetosomes. When isolated from the MTB, magnetosomes exceed synthetic magnetic nanoparticles exhibiting promising anti-tumor efficacy against glioblastoma tumors in vivo tests $[372,373]$. It should be emphasized, however, that the anticancer activity is based on various mechanisms of action (heat, the release of chemotherapeutic drugs under a $\mathrm{pH}$ variation, nanoparticle excitation by radiation, and apoptotic tumor cell death). Magnetic nanoparticles are useful for targeted cancer therapies because they can be manipulated by external magnetic fields. Moreover, they are attracted toward hypoxic areas, such as the tumor regions, while retaining the therapeutic and imaging capacities of the isolated magnetosomes [374]. In nature, we can find other examples of a variety of nanomaterials synthesized by biological processes like example diatoms, which synthesize siliceous materials or S-layer bacteria forming NPs of gypsum and calcium carbonate layers.

\subsection{Plant Extracts-Mediated NPS Synthesis}

Plant extracts contain diverse compounds, which can be utilized as potent reducing agents, stabilizing agents, and precursor molecules for NPs formation [375,376]. In order 
to prepare the extracts, both the biomass of the whole plant and selected parts such as leaves, fruit, seeds, and above-ground parts can be used. The plant material can be fresh or powder-dried. Various techniques are used to prepare the extracts, but most consist of classical maceration with various solvents including water or water-alcohol mixtures. Nanoparticle synthesis is mediated by extract components with reducing potential including alkaloids, terpenoids, polyphenols, phenols, flavonoids, and proteins, which have additionally been identified as nanoparticle stabilizers. As compared with ordinary metal salts or initial materials alone, biologically synthesized nanoparticles have been found to be better scavengers of free radicals [377]. The antioxidant activity of NPs frequently depends on their size [378,379] as well as shape [380,381].

So far, many examples of the phytogenic synthesis of NPs have been described, including, among others, copper oxide and copper nanoparticles by the use of the leaf extract of Cissus arnotiana with antioxidant ability [382,383]. Apart from zinc oxide (ZnONPs), selenium (SeNPs), and nickel oxide nanoparticles (NiONPs), one of the biggest groups of plant-mediated NPs is iron nanoparticles (INPs). This group is divided into (a) iron oxide nanoparticles (IONs), (b) iron oxide hydroxide (FeOOH) nanoparticles, and (c) zero-valent iron (ZVI) nanoparticles [384-387]. Iron oxide (magnetite $\mathrm{Fe}_{3} \mathrm{O}_{4}$, magemite $\mathrm{Fe}_{2} \mathrm{O}_{3}$ ) NPs of certain sizes have superparamagnetic properties; therefore, they are useful as contrast agents and drug carriers.

The main problems encountered in the biogenic synthesis of nanoparticles concern achieving their appropriate shape, size, and monodispersity in the solution phase. Undoubtedly, the size and shape of NPs depend on the synthesis conditions and the chemical composition of the extract. Usually, optimization of synthesis conditions concerns such factors as the extract concentration, $\mathrm{pH}$, temperature, and reaction or incubation time [388-391]. The reports on a plant-mediated approach to synthesize NPs by the use of different extracts are collected in Table 4.

Table 4. Examples of biosynthesis of nanoparticles (NPs).

\begin{tabular}{|c|c|c|c|c|c|c|}
\hline Shape/Size & $\begin{array}{l}\text { Activity Assay/ } \\
\text { Control }\end{array}$ & $\begin{array}{l}\text { Biological } \\
\text { Material }\end{array}$ & $\begin{array}{l}\text { Effective } \\
\text { Molecules }\end{array}$ & Preparation of Extract & Bio-Synthesis of NPs & Ref. \\
\hline \multicolumn{7}{|c|}{$\begin{array}{c}\text { Silver (Ag) NPs, } \\
\text { Absorbance at } 430-450 \mathrm{~nm}\end{array}$} \\
\hline $\begin{array}{l}\text { spherical } \\
410-450 \mathrm{~nm}\end{array}$ & $\begin{array}{l}\text { DPPH/ } \\
\text { ascorbic acid }\end{array}$ & Lantana camara L. & terpenes & $\begin{array}{l}\text { Powder }(10 \mathrm{gm}) \text { of dried leaves } \\
\text { was extracted with petroleum } \\
\text { ether }(30 \mathrm{~mL}) \text { at } \mathrm{RT} \text { for } 6 \mathrm{~h} \text { with } \\
\text { shaking. It was treated with } \\
30 \mathrm{~mL} \text { of warm } 10 \% \text { aqueous } \\
\mathrm{KOH} \text {, shaken and two layers } \\
\text { were separated. The petroleum } \\
\text { ether layer was concentrated to } \\
\text { dryness under } \\
\text { reduced pressure. }\end{array}$ & $\begin{array}{l}\text { One milliliter of } \\
\text { concentrated extract was } \\
\text { added to } 6 \mathrm{~mL} \text { of } 1 \mathrm{mM} \\
\mathrm{AgNO}_{3} \text { at } \mathrm{RT} \text {, and kept } \\
\text { in the dark for } 24 \mathrm{~h} \text {. The } \\
\text { slurry was dried } \\
\text { under vacuum. }\end{array}$ & [392] \\
\hline spherical 5-38 nm & $\begin{array}{l}\mathrm{DPPH} / \text { ascorbic } \\
\text { acid }\end{array}$ & Costus afer & $\begin{array}{l}\text { Carbohydrates } \\
\text { flavonoids, } \\
\text { phenolics, alkaloids, } \\
\text { organic acids }\end{array}$ & $\begin{array}{l}\text { Fresh leaves were air-dried. } \\
\text { Two grams of the powder was } \\
\text { macerated with } 150 \mathrm{~mL} \mathrm{DW} \\
\text { and heated at } 90^{\circ} \mathrm{C} \text { for } 1 \mathrm{~h} \text {. }\end{array}$ & $\begin{array}{l}\text { Eighty milliliters of } \\
\text { filtered extract was } \\
\text { mixed with } 400 \mathrm{~mL} \text { of } \\
1 \mathrm{mM} \mathrm{AgNO} \text {. The } \\
\text { mixture was stirred at } 90 \\
{ }^{\circ} \mathrm{C} \text { for } 120 \text { min. }\end{array}$ & [393] \\
\hline $\begin{array}{l}\text { spherical } \\
5-30 \mathrm{~nm}\end{array}$ & $\begin{array}{l}\text { ABTS, DPPH, } \\
\text { NO f.r.s.a. }\end{array}$ & $\begin{array}{l}\text { Taraxacum } \\
\text { officinale }\end{array}$ & $\begin{array}{l}\text { flavonoids, primary } \\
\text { aromatic } \\
\text { amines, terpenoids, } \\
\text { triterpenes }\end{array}$ & $\begin{array}{l}\text { The dried leaves were } \\
\text { powdered and sieved. Five } \\
\text { grams of powder was added to } \\
50 \mathrm{~mL} \text { of DW and boiled at } 60 \\
{ }^{\circ} \mathrm{C} \text { for } 15 \mathrm{~min} \text {, followed by } \\
\text { cooling and filtration. }\end{array}$ & $\begin{array}{l}\text { The extract was mixed } \\
\text { with } \mathrm{AgNO}_{3}(1 \mathrm{mM}) \\
\text { with a } 1: 5 \text { ratio for } \\
15 \text { min. at } \mathrm{pH} 6.0 \text {, at RT. }\end{array}$ & [394] \\
\hline $\begin{array}{l}\text { spherical } \\
12-40 \mathrm{~nm} \text {. }\end{array}$ & $\begin{array}{l}\text { DPPH, ABTS, } \mathrm{O}_{2}{ }^{\bullet-} \text {, } \\
\mathrm{NO}^{\bullet} \text { f.r.s.a. }\end{array}$ & Morus alba & $\begin{array}{l}\text { carbohydratesproteins, } \\
\text { secondary } \\
\text { metabolites }\end{array}$ & $\begin{array}{l}\text { Ten grams of the chopped } \\
\text { leaves were refluxed with } \\
100 \mathrm{~mL} \text { DDW for } 60 \mathrm{~min} \text {. The } \\
\text { product was filtered and } \\
\text { centrifuged at } 2000 \mathrm{rpm} \text { for } \\
5 \mathrm{~min} \text {. }\end{array}$ & $\begin{array}{l}\text { Ten milliliters of extract } \\
\text { was mixed with } 90 \mathrm{~mL} \\
\mathrm{AgNO}_{3} \text { solution with } \\
\text { stirring for } 10 \mathrm{~min} .\end{array}$ & [395] \\
\hline $\begin{array}{l}\text { spherical } \\
50-60 \mathrm{~nm}\end{array}$ & DPPH/BHT & Thymus kotschyanus & $\begin{array}{l}\text { phenolic, flavonoid } \\
\text { compounds }\end{array}$ & $\begin{array}{l}\text { The plant was washed, dried at } \\
25^{\circ} \mathrm{C} \text {, powdered with mortar. } \\
\text { Two grams of powder was } \\
\text { added to } 300 \mathrm{~mL} \text { of boiling } \\
\text { water and kept for } 30 \mathrm{~min} \text {. The } \\
\text { obtained extract was filtered. }\end{array}$ & $\begin{array}{l}\text { The extract }(10 \mathrm{~mL}) \text { was } \\
\text { mixed with } 100 \mathrm{~mL} \text { of } \\
1 \mathrm{~m} \mathrm{M} \text { aqueous solution } \\
\text { of } \mathrm{AgNO}_{3} \text { at } \mathrm{RT} \text { and } \\
\text { stirred for } 30 \mathrm{~min} \text { in a } \\
\text { dark place. }\end{array}$ & [396] \\
\hline
\end{tabular}


Table 4. Cont.

\begin{tabular}{|c|c|c|c|c|c|c|}
\hline Shape/Size & $\begin{array}{l}\text { Activity Assay/ } \\
\text { Control }\end{array}$ & $\begin{array}{l}\text { Biological } \\
\text { Material }\end{array}$ & $\begin{array}{l}\text { Effective } \\
\text { Molecules }\end{array}$ & Preparation of Extract & Bio-Synthesis of NPs & Ref. \\
\hline $\begin{array}{l}\text { spherical } \\
5-45 \mathrm{~nm}\end{array}$ & $\begin{array}{l}\mathrm{DPPH}, \mathrm{H}_{2} \mathrm{O}_{2}, \mathrm{OH}^{\bullet}, \\
\mathrm{O}_{2}{ }^{\bullet-} \text { f.r.s.a. }\end{array}$ & Cestrum nocturnum & $\begin{array}{l}\text { phenolic } \\
\text { compounds, } \\
\text { amines, amides, } \\
\text { aldehydes, nitriles, } \\
\text { flavonoids, tannins }\end{array}$ & $\begin{array}{l}\text { The leaves were dried and } \\
\text { powdered. Eight grams of } \\
\text { powder was added to } 100 \mathrm{~mL} \\
\text { DI and heated at } 70{ }^{\circ} \mathrm{C} \text { for } 2 \mathrm{~h} \text {. } \\
\text { The extract was centrifuged at } \\
3000 \text { rpm for } 5 \text { min followed } \\
\text { the filtration. }\end{array}$ & 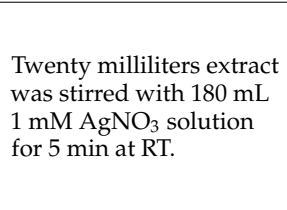 & [397] \\
\hline $\begin{array}{l}\text { spherical } \\
5-50 \mathrm{~nm}\end{array}$ & $\begin{array}{l}\text { DPPH, FRAP, } \\
\text { TAC/ascorbic acid }\end{array}$ & $\begin{array}{l}\text { Streptomyces } \\
\text { naganishii }(M A 7)\end{array}$ & Proteins, enzymes & $\begin{array}{l}\text { The strain was inoculated into } \\
50 \mathrm{~mL} \text { of ISP 2. The mycelium } \\
\text { was centrifugated at } 5000 \mathrm{rpm} \\
\text { for } 30 \mathrm{~min} \text {. }\end{array}$ & $\begin{array}{l}\text { Five grams of wet } \\
\text { biomass was exposed to } \\
50 \mathrm{~mL} \text { of } 1 \mathrm{mM} \mathrm{AgNO} \text {. } \\
\text { The mixture was } \\
\text { incubated for } 28^{\circ} \mathrm{C} \text { at } \\
120 \mathrm{rpm} \text {, and then } \\
\text { ultracentrifugation. }\end{array}$ & [398] \\
\hline $\begin{array}{l}\text { variables } \\
150-250 \mathrm{~nm}\end{array}$ & DPPH, FRAP, TAC & $\begin{array}{l}\text { Parmeliopsis ambigua, } \\
\text { Punctelia subrudecta } \\
\text { Evernia mesomorpha, } \\
\text { Xanthoparmelia } \\
\text { plitti mycelia } \\
\text { mats }\end{array}$ & $\begin{array}{l}\text { polyphenols, native } \\
\text { proteins }\end{array}$ & $\begin{array}{l}\text { The cultures were inoculated on } \\
\text { MYE. The plates were } \\
\text { incubated at } 28^{\circ} \mathrm{C} \text {. After } \\
7-10 \text { days, the isolated } \\
\text { mycobiont was subcultured } \\
\text { into a fresh medium. The } \\
\text { mycobiont was grown } \\
\text { aerobically in MYE at } 28^{\circ} \mathrm{C} \\
\text { with shaking at } 150 \mathrm{rpm} \text {. After } \\
10 \text { days, mycelia were } \\
\text { separated by filtration. }\end{array}$ & $\begin{array}{l}\text { The mycelia mats were } \\
\text { mixed separately with } \\
100 \mathrm{~mL} \text { SDW and } 1 \mathrm{mM} \\
\mathrm{AgNO}_{3} \text {, and incubated } \\
\text { at } \mathrm{RT} \text { on a rotary shaker } \\
\text { at } 150 \mathrm{rpm} \text {. The reaction } \\
\text { was carried out in bright } \\
\text { conditions for } 24 \mathrm{~h} \text {. }\end{array}$ & [399] \\
\hline $\begin{array}{l}\text { spherical } \\
15-30 \mathrm{~nm}\end{array}$ & DPPH & $\begin{array}{l}\text { marine algae } \\
\text { Ecklonia cava }\end{array}$ & $\begin{array}{l}\text { polyphenols, } \\
\text { polysaccharides, } \\
\text { amine, amide } \\
\text { species }\end{array}$ & $\begin{array}{l}\text { Five grams of powder and } \\
500 \mathrm{~mL} \text { of DW were kept at } \\
100^{\circ} \mathrm{C} \text { for } 1 \mathrm{~h} \text {. Then, the } \\
\text { mixture was centrifuged at } \\
3000 \mathrm{rpm} \text { for } 20 \mathrm{~min} \text {, and } \\
\text { filtered by a filter paper. }\end{array}$ & $\begin{array}{l}\text { Ten milliliters of } \\
\text { aqueous extract was } \\
\text { mixed with } 90 \mathrm{~mL} \text { of } \\
1 \mathrm{mM} \mathrm{AgNO} \text { solution } \\
\text { and stirred for } 72 \mathrm{~h} \text {. } \\
\text { AgNPs were lyophilized. }\end{array}$ & [400] \\
\hline spherical 2-10 nm & DPPH, $\mathrm{H}_{2} \mathrm{O}_{2}$ f.r.s.a. & $\begin{array}{l}\text { Pestalotiopsis } \\
\text { microspora VJ1/VS1 }\end{array}$ & $\begin{array}{l}\text { phenolic } \\
\text { compounds, } \\
\text { proteins }\end{array}$ & $\begin{array}{l}\text { The culture was cultivated in } \\
100 \mathrm{~mL} \text { of PDB at } 25^{\circ} \mathrm{C} \text {. After } \\
6 \text { days fungal biomass was } \\
\text { transferred to } 100 \mathrm{~mL} \text { of SDDW, } \\
\text { boiled, and filtered. }\end{array}$ & 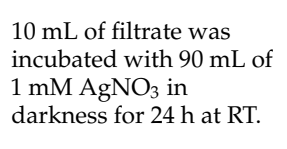 & [401] \\
\hline $100 \mathrm{~nm}$ & $\begin{array}{l}\mathrm{DPPH} / \\
\text { ascorbic acid }\end{array}$ & $\begin{array}{l}\text { Cladosporium } \\
\text { cladosporioides - }\end{array}$ & $\begin{array}{l}\text { NADPH-dependent } \\
\text { reductase, phenolic } \\
\text { compounds, } \\
\text { proteins }\end{array}$ & $\begin{array}{l}\text { The mycelial was grown in PDB } \\
\text { for } 72 \mathrm{~h} \text {. The biomass was } \\
\text { filtered and then incubated at } \\
\text { RT for } 48 \mathrm{~h} \text { in } 100 \mathrm{~mL} \text { DW. }\end{array}$ & $\begin{array}{l}\text { Ten milliliters of filtrate } \\
\text { was added to } 90 \mathrm{~mL} \text { of } \\
1 \mathrm{mM} \mathrm{AgNO}_{3} \text {. }\end{array}$ & [402] \\
\hline spherical 3-40 nm & $\begin{array}{l}\mathrm{DPPH} / \\
\text { ascorbic acid }\end{array}$ & $\begin{array}{l}\text { Aspergillus versicolor } \\
\text { ENT7-isolated from } \\
\text { the ethnomedicinal } \\
\text { plant Centella } \\
\text { asiatica. }\end{array}$ & - & $\begin{array}{l}\text { The fungal isolate was grown in } \\
100 \mathrm{~mL} \text { of PDB at } 26^{\circ} \mathrm{C} \text { with } \\
\text { shaking at a speed of } 100 \mathrm{rpm} \text {. } \\
\text { After the seventh day, the } \\
\text { fungal biomass was separated } \\
\text { and washed with SDDW. } 10 \mathrm{~g} \\
\text { of biomass was mixed with } \\
100 \mathrm{~mL} \text { SDDW and kept at } \\
28^{\circ} \mathrm{C} \text { for } 72 \mathrm{~h} \text { in a } \\
\text { constant shaking. }\end{array}$ & $\begin{array}{l}\text { The aqueous solution } \\
\text { was filtered }(100 \mathrm{~mL}) \\
\text { and added to } 100 \mathrm{~mL} \text { of } \\
1 \mathrm{mM} \text { of silver nitrate } \\
\text { and incubated at } 28^{\circ} \mathrm{C} \\
\text { for } 24 \mathrm{~h} \text { in } \\
\text { dark condition. }\end{array}$ & [403] \\
\hline $15-25 \mathrm{~nm}$ & DPPH & $\begin{array}{l}\text { Trichoderma } \\
\text { atroviride KNUP001 }\end{array}$ & - & $\begin{array}{l}\text { The freshly prepared mycelial } \\
\text { filtrate was prepared by } \\
\text { aerobically growing in PDB } \\
\text { with the agitation of } 180 \mathrm{rpm} \text { at } \\
28^{\circ} \mathrm{C} \text { for } 4 \text { days. Then, the } \\
\text { biomass was filtrated and } \\
\text { washed SDDW. The biomass } \\
(20 \mathrm{~g}) \text { was ground in } 100 \mathrm{~mL} \text { of } \\
\text { deionized water and filtered. }\end{array}$ & $\begin{array}{l}\text { The filtrate }(100 \mathrm{~mL}) \text { was } \\
\text { mixed with } \mathrm{AgNO}_{3} \\
(5 \mathrm{mM} \text { or } 10 \mathrm{mM}) \text { and } \\
\text { the solution was kept at } \\
40^{\circ} \mathrm{C} \text { under darkness. }\end{array}$ & [404] \\
\hline $\begin{array}{l}\text { spherical } \\
65 \mathrm{~nm}\end{array}$ & $\begin{array}{l}\text { DPPH, } \\
\text { FRAP/ascorbic acid }\end{array}$ & $\begin{array}{l}\text { endophytic fungi, } \\
\text { Penicillium species } \\
\text { of Glycosmis } \\
\text { mauritiana }\end{array}$ & $\begin{array}{l}\text { tannins, saponins, } \\
\text { terpenoids } \\
\text { flavonoids, }\end{array}$ & $\begin{array}{l}\text { Sterilized }\left(\mathrm{HgCl}_{2}, 1 \mathrm{mg} \mathrm{ml}^{-1}\right) \\
\text { bark material was incubated in } \\
\text { PDA at RT for } 7-8 \text { days. The } \\
\text { isolated fungi were cultured in } \\
\text { PDB for } 10 \text { days. The mycelial } \\
\text { mat was centrifuged ( } 6000 \mathrm{rpm} \text {, } \\
10 \text { min) and the supernatant } \\
\text { was shaken for } 24 \mathrm{~h} \text {. }\end{array}$ & $\begin{array}{l}\text { Eighty milliliters of } \\
3 \mathrm{mM} \mathrm{AgNO}_{3} \text { was } \\
\text { added to } 20 \mathrm{~mL} \text { of } \\
\text { extract. NPs were } \\
\text { centrifugated at } \\
7000 \mathrm{rpm} \text { for } 10 \mathrm{~min} .\end{array}$ & [405] \\
\hline $\begin{array}{l}\text { spherical } \\
15-35 \mathrm{~nm}\end{array}$ & ABTS/BHT & Inonotus obliquus & proteins & $\begin{array}{l}\text { Ten grams of mushrooms were } \\
\text { washed, crushed mixed with } \\
200 \mathrm{~mL} \text { DDW, and stirred for } \\
\text { about half an hour. }\end{array}$ & 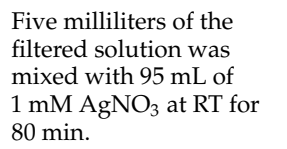 & [406] \\
\hline
\end{tabular}


Table 4. Cont.

\begin{tabular}{|c|c|c|c|c|c|c|}
\hline Shape/Size & $\begin{array}{l}\text { Activity Assay/ } \\
\text { Control }\end{array}$ & $\begin{array}{l}\text { Biological } \\
\text { Material }\end{array}$ & $\begin{array}{l}\text { Effective } \\
\text { Molecules }\end{array}$ & Preparation of Extract & Bio-Synthesis of NPs & Ref. \\
\hline spherical & $\begin{array}{l}\text { FRAP, DPPH, } \\
\text { /ascorbic acid }\end{array}$ & Cladosporium & $\begin{array}{l}\text { carbohydratestannin, } \\
\text { phenolic glycosides, } \\
\text { terpenoids, } \\
\text { alkaloids, phenol } \\
\text { anthraquinones, } \\
\text { flavanones }\end{array}$ & $\begin{array}{l}\text { The species was cultured using } \\
\text { PDB for } 15 \text { days at RT. }\end{array}$ & $\begin{array}{l}\text { Five grams of dried and } \\
\text { milled mycelia mat was } \\
\text { mixed with } 20 \mathrm{~mL} \text { of } \\
\text { SDDW, The mixture was } \\
\text { heated to } 100^{\circ} \mathrm{C} \text { for } \\
10 \mathrm{~min} \text {. Then, } 10 \mathrm{~mL} \text { of } \\
5 \mathrm{mM} \mathrm{AgNO}_{3} \\
\text { was added. }\end{array}$ & [407] \\
\hline $10-80 \mathrm{~nm}$ & DPPH & $\begin{array}{l}\text { Agaricus bisporus, } \\
\text { Ganoderma lucidum }\end{array}$ & $\begin{array}{l}\text { flavoproteins, } \\
\text { lysine, tryptophan, } \\
\text { glutamic acid, } \\
\text { riboflavin }\end{array}$ & $\begin{array}{l}\text { Fresh mushrooms were washed } \\
\text { with DDW, dried for } 4 \text { days, } \\
\text { powdered. } 1 \mathrm{~g} \text { of powder was } \\
\text { added to } 100 \mathrm{~mL} \text { of DDW, and } \\
\text { stirred for } 60 \mathrm{~min} \text {. }\end{array}$ & $\begin{array}{l}\text { The filtered extract } \\
(10 \mathrm{~mL}) \text { was added to } \\
90 \mathrm{~mL} \text { of } 1 \mathrm{mM} \mathrm{AgNO} \text {. } \\
\text { This solution was kept at } \\
\text { RT for } 12 \mathrm{~h} \text { or heated at } \\
60^{\circ} \mathrm{C} \text { for } 5 \mathrm{~h} \text {. }\end{array}$ & [408] \\
\hline $\begin{array}{l}\text { spherical } \\
15-22 \mathrm{~nm}\end{array}$ & $\begin{array}{l}\mathrm{DPPH} / \text { trolox, } \\
\text { ascorbic acid }\end{array}$ & Ganoderma lucidum & $\begin{array}{l}\text { proteins, steroids, } \\
\text { nucleotides, amino } \\
\text { acids, terpenoids, } \\
\text { phenols, vitamins, } \\
\text { glycoproteins, } \\
\text { poly-saccharides }\end{array}$ & $\begin{array}{l}\text { Five grams of powdered } \\
\text { mushrooms were added to } \\
100 \text { mL of } 70 \% \text { ethanol solution. } \\
\text { The extract was prepared by the } \\
\text { microwave-assisted process. }\end{array}$ & $\begin{array}{l}\text { Twenty milliliters of } \\
\text { filtered extract was } \\
\text { diluted to } 100 \mathrm{~mL} \text { by } \\
\text { DDW, and then } 15 \mathrm{mg} \text { of } \\
\mathrm{AgNO}_{3} \text { was added and } \\
\text { mixed by the magnetic } \\
\text { stirrer system. }\end{array}$ & [409] \\
\hline $\begin{array}{l}\text { spherical } \\
10-30 \mathrm{~nm}\end{array}$ & DPPH & Ganoderma lucidum & $\begin{array}{l}\text { polyphenol, } \\
\text { carbonyl species, } \\
\text { amino acid }\end{array}$ & $\begin{array}{l}\text { The sample was washed with } \\
\mathrm{DW} \text { and dried at } 40^{\circ} \mathrm{C} \text { for } \\
3 \text { days. The dried sample was } \\
\text { grounded into a powder. } 5 \mathrm{~g} \text { of } \\
\text { powder was extracted using } \\
\text { water }(20 \mathrm{~mL} \text { via Soxhlet } \\
\text { extractor at } 80^{\circ} \mathrm{C} \text { for } 8 \mathrm{~h} \text {. The } \\
\text { extract was filtered, and } \\
\text { concentrated to } 100 \mathrm{~mL} \text { under } \\
60^{\circ} \mathrm{C} \text { in a rotary evaporator. }\end{array}$ & $\begin{array}{l}\text { Ten millilitres of extract } \\
\text { was added to } 90 \mathrm{~mL} \text { of } \\
1 \mathrm{mM} \mathrm{AgNO}_{3} \text { solution } \\
\text { and incubated at } 60{ }^{\circ} \mathrm{C} \\
\text { in dark, with an interval } \\
\text { the stirring for } 4 \mathrm{~h} \text { of } \\
\text { incubation. } \mathrm{Ag}-\mathrm{NPs} \\
\text { were collected by } \\
\text { centrifugation at } \\
10,000 \text { rpm for } 30 \text { min at } \\
4{ }^{\circ} \mathrm{C} \text {. The pellet was } \\
\text { washed and dried } \\
\text { at } 60^{\circ} \mathrm{C} \text {. }\end{array}$ & [410] \\
\hline
\end{tabular}

The pure culture was

inoculated on ISP-2 broth and incubated at $28^{\circ} \mathrm{C}$ and $130 \mathrm{rpm}$ for 7 days. After that, the culture was centrifuged at $4000 \mathrm{rpm}$ for $20 \mathrm{~min}$ and the biomass was washed with DW, suspended in DW, and incubated at $28^{\circ} \mathrm{C}$ and $130 \mathrm{rpm}$ for $48 \mathrm{~h}$, and finally centrifuged at $4000 \mathrm{rpm}$.

The fresh leaves were washed, pat dried, and chopped, shade-dried to constant mass at RT. Ratio: product/solvent was kept at 1:12 w:v, extraction time: 3 h. mechanical stirring, temperature: $70^{\circ} \mathrm{C}$ (hydroalcoholic mixture), $67^{\circ} \mathrm{C}$ (ethanol); microwave-assisted extraction: time: $10 \mathrm{~min}$ at $140{ }^{\circ} \mathrm{C}$, max. power $1000 \mathrm{~W}$.

Gold (Au) NPs, Absorbance at 530-535 nm

multiply twinned quasispherical DPPH

\section{Acroscyphus} sphaerophoroides Lev, Sticta nylanderiana carboxylic acids, esters, phenols, quinones
The samples were cleaned with DDW, shade dried, and ground in a glass mortar.
One hundred milliliters of each filtered extract were mixed with $100 \mathrm{~mL}$ of $10 \mathrm{mM}$ aqueous $\mathrm{AgNO}_{3}$ solution and incubated at RT for $30 \mathrm{~min}$.

One gram of powder was stirred with $100 \mathrm{~mL}$ aqueous solution $\left(10^{-3}\right.$

M) of $\mathrm{HAuCl}_{4}$, at $\mathrm{RT}$ for $12 \mathrm{~h}$. The supernatant was centrifugated $(10,000 \mathrm{rpm})$. The 
Table 4. Cont.

\begin{tabular}{|c|c|c|c|c|c|c|}
\hline Shape/Size & $\begin{array}{l}\text { Activity Assay/ } \\
\text { Control }\end{array}$ & $\begin{array}{l}\text { Biological } \\
\text { Material }\end{array}$ & $\begin{array}{l}\text { Effective } \\
\text { Molecules }\end{array}$ & Preparation of Extract & Bio-Synthesis of NPs & Ref. \\
\hline $\begin{array}{l}\text { Spherical } \\
5-15 \mathrm{~nm}\end{array}$ & $\mathrm{DPPH}$ & $\begin{array}{l}\text { Lemanea fluviatilis } \\
\text { (L.) }\end{array}$ & proteins & $\begin{array}{l}\text { The red alga samples were } \\
\text { cleaned by DW and then dried } \\
\text { for a one week in a dark place. }\end{array}$ & $\begin{array}{l}\text { One gram of powder } \\
\text { was stirred with } 100 \mathrm{~mL} \\
\text { aqueous solution }\left(10^{-3}\right. \\
\text { M) of } \mathrm{HAuCl}_{4} \text {, at RT for } \\
12 \mathrm{~h} \text {. The supernatant } \\
\text { was centrifugated } \\
(10,000 \mathrm{rpm}) \text {. The } \\
\text { biomass was washed } \\
\text { with DDW and dried. }\end{array}$ & [143] \\
\hline spherical $79 \mathrm{~nm}$ & - & Tetraselmis suecica & $\begin{array}{l}\text { water-soluble } \\
\text { heterocyclic } \\
\text { compounds }\end{array}$ & $\begin{array}{l}\text { The cultures were harvested on } \\
\text { the sixth day, then centrifuged } \\
\text { at } 2000 \mathrm{~g} \text { for } 10 \text { min at } 4{ }^{\circ} \mathrm{C} \text {. The } \\
\text { biomass was washed with } 0.9 \% \\
\mathrm{NaCl} \text { and centrifuged. The cells } \\
\text { were damaged in a mortar in a } \\
\text { presence of liquid } \mathrm{N}_{2} \text { and then } \\
\text { again centrifuged under the } \\
\text { same conditions. }\end{array}$ & $\begin{array}{l}\text { The cell extracts were } \\
\text { added to } 4 \mathrm{~mL} \text { of } 1 \mathrm{mM} \\
\mathrm{HAuCl}_{4} \text {. The mixtures } \\
\text { were incubated in a } \\
\text { water bath. The } \\
\text { recommended } \\
\text { conditions: } 1 \mathrm{~mL} \text { of } \\
\text { extract, } 5 \mathrm{~min} \text { of } \\
\text { incubation, } 90^{\circ} \mathrm{C} \text { of } \\
\text { incubation temperature. }\end{array}$ & [414] \\
\hline $\begin{array}{l}\text { triangular, } \\
\text { circular, } \\
\text { hexagonal }\end{array}$ & $\begin{array}{l}\text { DPPH/ } \\
\text { ascorbic acid }\end{array}$ & Escherichia coli & - & $\begin{array}{l}\text { E. coli was grown in a nutrient } \\
\text { broth at } 25^{\circ} \mathrm{C} \text { under agitation } \\
\text { at } 180 \mathrm{rpm} \text {. The biomass sieved } \\
\text { and washed with } \mathrm{DW} .1 \mathrm{mg} \text { of } \\
\text { biomass mixed with } 50 \mathrm{~mL} \text { of } \\
\text { SDW, and after } 24 \mathrm{~h}, \\
\text { precipitated by } \mathrm{NH}_{4}\left(\mathrm{SO}_{4}\right)_{2} \text {. The } \\
\text { pellet was dissolved in } \\
\text { phosphate buffer }(0.05 \mathrm{M}, \mathrm{pH} \\
\text { 8.0) and dialyzed. }\end{array}$ & $\begin{array}{l}\text { Five milliliters of } \\
\text { solution }(50 \mathrm{mg} \text { of } \\
\mathrm{HAuCl}_{4} \text { in } 250 \mathrm{~mL} \text { of } \\
\text { water) was mixed with } \\
24 \text { or } 30 \mathrm{~mL} \text { of the } \\
\text { protein solution and } \\
\text { vigorously stirred } \\
\text { for } 4 \mathrm{~h} \text {. }\end{array}$ & [415] \\
\hline spherical & $\begin{array}{l}\mathrm{DPPH}, \mathrm{OH}, \mathrm{O}_{2}{ }^{--} \\
\mathrm{NO}^{\bullet} \text { f.r.s.a. }\end{array}$ & Solanum torvum & - & $\begin{array}{l}\text { The dried fruit was made to a } \\
\text { fine powder. The } 1 \% \text { of } \\
\text { aqueous extract was obtained } \\
\text { by using soxhlet apparatus. }\end{array}$ & $\begin{array}{l}\text { Eight milliliters of } \\
\text { extract was mixed with } \\
2 \mathrm{~mL} \text { of } 1 \mathrm{mM} \mathrm{HAuCl} \\
\text { and incubated at } \mathrm{RT} \text { for } \\
24 \mathrm{~h} \text {, then the mixture } \\
\text { was centrifuged at } \\
10,000 \text { rpm for } 10 \mathrm{~min} . \\
\text { The pellet was } \\
\text { re-suspended in ethanol. }\end{array}$ & [416] \\
\hline $\begin{array}{l}\text { spherical } \\
13-15 \mathrm{~nm}\end{array}$ & - & $\begin{array}{l}\text { Phormidium } \\
\text { valderianum, P.tenue, } \\
\text { Microcoleus } \\
\text { chthonoplastes, } \\
\text { Rhizoclonium } \\
\text { fontinale, } \\
\text { Ulva intestinalis, } \\
\text { Chara zeylanica, } \\
\text { Pithophora } \\
\text { oedogoniana }\end{array}$ & - & $\begin{array}{l}\text { The samples were cultured in } \\
\text { an artificial seawater medium. } \\
\text { Algal biomass was mixed with } \\
\text { betadine and antibiotic } \\
\text { mixtures. After } 12 \text { the biomass } \\
\text { was washed with SDW. }\end{array}$ & $\begin{array}{l}\text { Au-loaded biomass was } \\
\text { obtained by its expose to } \\
15 \text { ppm Au (III) solution } \\
\text { at pH }(5,7,9) \text {. After } 72 \mathrm{~h} \text {, } \\
\text { it was washed with } \\
\text { SDDW, and dried on air. } \\
\text { The biomass was } \\
\text { sonicated for } 30 \text { min } \\
\text { with } 7.5 \text { mM sodium } \\
\text { citrate, followed by } \\
\text { centrifugation of } 5 \text { min } \\
\text { at } 3000 \text { rpm. }\end{array}$ & [417] \\
\hline $100 \mathrm{~nm}$ & DPPH, FRAP & $\begin{array}{l}\text { Cladosporium } \\
\text { cladosporioides }\end{array}$ & $\begin{array}{l}\text { NADPH- } \\
\text { dependent } \\
\text { reductase, phenolic } \\
\text { compounds }\end{array}$ & $\begin{array}{l}\text { The endophytic fungal isolates } \\
\text { were cultured using PDB for } \\
21 \text { days at } 25 \text { to } 28^{\circ} \mathrm{C} \text {. The } \\
\text { biomass was filtered and } \\
\text { washed with DW. This biomass } \\
\text { was incubated at RT for } 48 \mathrm{~h} \text { in } \\
100 \text { mL DW. }\end{array}$ & $\begin{array}{l}\text { A } 1 \mathrm{mM} \mathrm{HAuCl}_{4} \\
\text { solution was mixed with } \\
\text { the fungal } \\
\text { suspension filtrate. }\end{array}$ & [402] \\
\hline $\begin{array}{l}\text { spherical, } \\
\text { triangle, } \\
\text { hexagonal rod } \\
23 \mathrm{~nm}\end{array}$ & ABTS & Inonotus obliquus & proteins & $\begin{array}{l}\text { Ten grams of cut mushrooms } \\
\text { were stirred with } 100 \mathrm{~mL} \text { of } \\
\text { DDW, for } 30 \text { min. Then, the } \\
\text { solution was filtered through } \\
\text { Whatman filter paper. }\end{array}$ & $\begin{array}{l}\text { The extract }(5 \mathrm{~mL}) \text { was } \\
\text { added to } 95 \mathrm{~mL}, 1.0 \mathrm{mM} \\
\mathrm{HAuCl}_{4} \text {. The mixture } \\
\text { was stirred at RT for } \\
30 \text { min. }\end{array}$ & [418] \\
\hline spherical 5-30 nm & DPPH & $\begin{array}{l}\text { Lactobacillus } \\
\text { kimchicus } \\
\text { DCY51T } 19\end{array}$ & - & $\begin{array}{l}\text { Bacterial cells isolated from } \\
\text { kimchi were inoculated into } \\
100 \mathrm{~mL} \text { MRS broth and } \\
\text { incubated at } 37^{\circ} \mathrm{C} \text { for } 24 \mathrm{~h} \text {. } \\
\text { After incubation, the broth was } \\
\text { centrifuged at } 6300 \times g \text { for } \\
5 \text { min. }\end{array}$ & $\begin{array}{l}\text { The biomass was } \\
\text { washed with SDW and } \\
\text { resuspended in } 15 \mathrm{~mL} \text { of } \\
\text { SDW. Then, } 1 \mathrm{mM} \text { of } \\
\text { gold salt was added. The } \\
\text { mixture was incubated } \\
\text { at } 30^{\circ} \mathrm{C} \text { and shaken at } \\
150 \times g \text { in darkness. The } \\
\text { product was centrifuged } \\
\text { at } 2500 \times g \text { for } 5 \text { min. }\end{array}$ & [419] \\
\hline
\end{tabular}


Table 4. Cont.

\begin{tabular}{|c|c|c|c|c|c|c|}
\hline Shape/Size & $\begin{array}{l}\text { Activity Assay/ } \\
\text { Control }\end{array}$ & $\begin{array}{l}\text { Biological } \\
\text { Material }\end{array}$ & $\begin{array}{l}\text { Effective } \\
\text { Molecules }\end{array}$ & Preparation of Extract & Bio-Synthesis of NPs & Ref. \\
\hline spherical 8-50 nm & DPPH & Enterococcus species & $\begin{array}{l}\text { proteins and other } \\
\text { nitrogenous } \\
\text { molecules }\end{array}$ & $\begin{array}{l}\text { A distinct colony of each strain } \\
\text { was used to inoculate } 10 \mathrm{~mL} \text { of } \\
\text { sterile broth and incubated at } \\
37^{\circ} \mathrm{C} \text { for } 18 \mathrm{~h} \text {. Then, the } \\
\text { cultures were centrifuged at } \\
4000 \mathrm{rpm} \text { at } 10^{\circ} \mathrm{C} \text { for } 15 \mathrm{~min} \text {. }\end{array}$ & $\begin{array}{l}\text { One milliliter of the } \\
\text { cell-free extract and } \\
30 \mathrm{~mL} \text { of } 1 \mathrm{mM} \mathrm{HAuCl}_{4} \\
\text { solution were mixed. }\end{array}$ & [420] \\
\hline $8-12 \mathrm{~nm}$ & - & Sargassum wightii & - & $\begin{array}{l}\text { Seaweed was cleaned, dried for } \\
3-5 \text { days, ground to powder. }\end{array}$ & $\begin{array}{l}\text { One gram of seaweed } \\
\text { powder was added to } \\
100 \mathrm{~mL} \text { of } 1 \mathrm{mM} \mathrm{HAuCl} \\
\text { solution within } 12 \mathrm{~h} \text { in a } \\
\text { stirring condition. }\end{array}$ & [421] \\
\hline $\begin{array}{l}\text { Spherical, cubic } \\
15-60 \mathrm{~nm}\end{array}$ & - & S. platensis & - & $\begin{array}{l}\text { The strain was cultivated in a } \\
\text { standard Zaroukh water-salt } \\
\text { nutrient medium. After } \\
5-6 \text { days of cultivation, the } \\
\text { bacterial cells were harvested } \\
\text { and then were washed in DW. }\end{array}$ & $\begin{array}{l}\text { The wet biomass }(1 \mathrm{~g}) \\
\text { was mixed with } 100 \mathrm{~mL} \\
\text { of } \mathrm{HAuCl}_{4} \text { solution } \\
\left(10^{-2}-10^{-4} \mathrm{M}\right) \text {. The } \\
\text { mixture was shaken for } \\
5 \text { days at RT. }\end{array}$ & [422] \\
\hline $20-70 \mathrm{~nm}$ & DPPH, NO` f.r.s.a. & Vitex negundo & $\begin{array}{l}\text { Flavonoids, } \\
\text { polyphenols }\end{array}$ & $\begin{array}{l}\text { Leaves were dried for } 3 \text { days in } \\
\text { a dark place. The biomass }(10 \mathrm{~g}) \\
\text { was stirred with DDW }(50 \mathrm{~mL}) \\
\text { for } 12 \mathrm{~h} \text { at } 500 \mathrm{rpm} \text {. The extracts } \\
\text { were filtered and lyophilized. }\end{array}$ & $\begin{array}{l}\text { Lyophilized extract } \\
(0.5 \mathrm{~g}) \text { was reconstituted } \\
\text { in } 5 \mathrm{~mL} \text { DDW at } 100 \\
\mu \mathrm{mLL}^{-1} . \text { To } 1 \mathrm{~mL} \text { of } \\
\text { extract, } 20 \mathrm{~mL} \text { of } \\
\mathrm{HAuCl}_{4}(0.01 \mathrm{M}) \text { was } \\
\text { added drop-wise and } \\
\text { stirred at } 500 \mathrm{rpm} \text {. The } \\
\text { solution was } \\
\text { kept overnight. }\end{array}$ & [423] \\
\hline
\end{tabular}

Zinc oxide ( $\mathrm{ZnO}$ ) NPs,

Absorbance at 340-360 nm.

\begin{tabular}{|c|c|c|c|c|c|c|}
\hline $\begin{array}{l}\text { hexagonal } \\
10-61 \mathrm{~nm}\end{array}$ & DPPH & Pichia kudriavzevii & amino acids & $\begin{array}{l}\text { The yeast was grown on PDB in } \\
\text { a vibrating incubator at } 150 \mathrm{rpm} \\
\text { for } 72 \mathrm{~h} \text { at } 28^{\circ} \mathrm{C} \text {. Mycelia were } \\
\text { centrifugated }(10,000 \mathrm{rpm} \text {, } \\
\left.10 \mathrm{~min}, 4^{\circ} \mathrm{C}\right) \text {, washed with } \\
\text { SDW. } 20 \mathrm{~g} \text { of biomass was } \\
\text { suspended in } 100 \mathrm{~mL} \text { of SDW } \\
\text { and incubated for } 72 \mathrm{~h} \text {. Then, } \\
\text { biomass was filtrated. }\end{array}$ & $\begin{array}{l}\text { One hundred milliliters } \\
\text { of filtrate was added } \\
\text { to } 10 \mathrm{~mL} \text { of } 10 \mathrm{mM} \\
\mathrm{Zn}(\mathrm{Ac})_{2} \cdot 2 \mathrm{H}_{2} \mathrm{O} \text {, } \\
\text { incubated at } 35^{\circ} \mathrm{C} \text { with } \\
\text { agitation at } 150 \mathrm{rpm} \text { for } \\
12-36 \mathrm{~h} \text {. The biomass } \\
\text { was centrifugated at } \\
10,000 \mathrm{rpm} \text { for } 10 \mathrm{~min} \\
\text { and dried at } 1500^{\circ} \mathrm{C} \text { for } \\
6 \mathrm{~h} \text {. }\end{array}$ & [424] \\
\hline $20-40 \mathrm{~nm}$ & DPPH & Berberis aristata & $\begin{array}{l}\text { polyphenols, } \\
\text { alcohol, carboxylic } \\
\text { acid, ether ester } \\
\text { amino acid }\end{array}$ & $\begin{array}{l}\text { The leaves were washed, dry at } \\
\text { RT. Later } 10 \text { g of leaves were } \\
\text { cut, soaked in } 100 \mathrm{~mL} \text { of DDW, } \\
\text { heated at } 50^{\circ} \mathrm{C} \text { for } 10 \mathrm{~min} . \text {, } \\
\text { and filtered. }\end{array}$ & $\begin{array}{l}\text { Sixty milliliters of extract } \\
\text { was heated to } 70{ }^{\circ} \mathrm{C} \text { and } \\
\text { stirred with } 0.1 \mathrm{M} \\
\left.\mathrm{Zn}(\mathrm{Ac})_{2} \cdot 2 \mathrm{H}_{2} \mathrm{O}\right) \text { at basic } \\
\text { conditions. Then, the } \\
\text { solution was centrifuged } \\
\text { at } 6000 \mathrm{rpm} \text { for } \\
20-25 \mathrm{~min} \text {. }\end{array}$ & [425] \\
\hline \multicolumn{7}{|c|}{$\begin{array}{c}\text { Selenium (Se) NPs, } \\
\text { Absorbance at } 510 \mathrm{~nm}\end{array}$} \\
\hline $10-250 \mathrm{~nm}$ & DPPH, FRAP, TAC & $\begin{array}{l}\text { Streptomyces } \\
\text { minutiscleroticus } \\
\text { (M10A62) }\end{array}$ & $\begin{array}{l}\text { protein, peptide, } \\
\text { amine, amide } \\
\text { compounds }\end{array}$ & $\begin{array}{l}\text { A } 0.1 \mathrm{~g} \text { soil sample was plated } \\
\text { in starch casein agar plates } \\
\text { enriched with nystatin } \\
(100 \mu \mathrm{g} / \mathrm{mL}) \text { and nalidixic acid } \\
(20 \mu \mathrm{g} / \mathrm{mL}) \text {. The strain was } \\
\text { transferred to } 100 \mathrm{~mL} \text { of MYE } \\
\text { broth and incubated in a rotator } \\
\text { shaker }(200 \mathrm{rpm}) \text { for } 5 \text { days, } \\
\text { and centrifugated at } 5000 \mathrm{rpm} \\
\text { for } 30 \mathrm{~min}\end{array}$ & $\begin{array}{l}\text { Five grams of biomass } \\
\text { washed with } \mathrm{SDDW} \text { was } \\
\text { mixed with } 100 \mathrm{~mL} \text { of an } \\
\text { aqueous solution of } \\
1 \mathrm{mM} \mathrm{Na} \mathrm{SeO}_{3} \text { and kept } \\
\text { in a rotator shaker for } \\
72 \mathrm{~h} \text {. }\end{array}$ & [426] \\
\hline $30-300 \mathrm{~nm}$ & DCF in HUVEC & $\begin{array}{l}\text { Pantoea agglomerans } \\
\text { strain UC-32 }\end{array}$ & - & $\begin{array}{l}\text { Bacterial cells were cultivated } \\
\text { in TSB enriched with } 1 \mathrm{mM} \\
\mathrm{Na}_{2} \mathrm{SeO}_{3} \text { at } 25^{\circ} \mathrm{C} \text {. }\end{array}$ & $\begin{array}{l}\text { Cell suspensions were } \\
\text { sonicated at } 100 \mathrm{~W} \text { for } \\
2 \text { min and centrifuged at } \\
10,000 \times g \text { for } 10 \mathrm{~min} . \\
\text { Pellets were suspended } \\
\text { in SDS } 0.1 \% / 1 \mathrm{M} \mathrm{NaOH} \text {, } \\
\text { and centrifuged. }\end{array}$ & [427] \\
\hline $\begin{array}{l}\text { spherical } \\
\text { tetragonal } \\
14-26 \mathrm{~nm} \text {. }\end{array}$ & $\begin{array}{l}\text { DPPH/ ascorbic } \\
\text { acid }\end{array}$ & Ephedra aphylla & $\begin{array}{l}\text { phenolic } \\
\text { compounds, } \\
\text { flavonoid tannin }\end{array}$ & $\begin{array}{l}\text { Twenty grams of the dried } \\
\text { plants were shaken with } \\
200 \mathrm{~mL} \text { DW for } 30 \text { min in a } \\
\text { water bath at } 70^{\circ} \mathrm{C} \text {. The } \\
\text { mixture was filtered. }\end{array}$ & $\begin{array}{l}\text { Twenty milliliters of } \\
1 \mathrm{mM} \text { selenium sulfate } \\
\text { was stirred with } 20 \mathrm{~mL} \\
\text { of the plant extract for } \\
2 \mathrm{~h} \text { at RT. }\end{array}$ & [428] \\
\hline
\end{tabular}


Table 4. Cont.

\begin{tabular}{|c|c|c|c|c|c|c|}
\hline Shape/Size & $\begin{array}{l}\text { Activity Assay/ } \\
\text { Control }\end{array}$ & $\begin{array}{l}\text { Biological } \\
\text { Material }\end{array}$ & $\begin{array}{l}\text { Effective } \\
\text { Molecules }\end{array}$ & Preparation of Extract & Bio-Synthesis of NPs & Ref. \\
\hline \multicolumn{7}{|c|}{$\begin{array}{c}\text { Copper }(\mathrm{Cu}) \mathrm{NPs} \\
\text { Absorbance at } 350-380 \mathrm{~nm} .\end{array}$} \\
\hline $\begin{array}{l}\text { spherical } \\
60-90 \mathrm{~nm}\end{array}$ & $\begin{array}{l}\text { DPPH/ } \\
\text { ascorbic acid }\end{array}$ & Cissus arnotiana & - & $\begin{array}{l}\text { One gram of the powder of the } \\
\text { dried leaves was added to } \\
100 \mathrm{~mL} \text { DDW, boiled at } 70^{\circ} \mathrm{C} \\
\text { for } 30 \text { min. The mixture } \\
\text { was filtered. }\end{array}$ & $\begin{array}{l}\text { Ten milliliters of the } \\
\text { extract was stirred with } \\
90 \mathrm{~mL} \text { of } 10 \mathrm{mM} \text { of } \\
\mathrm{CuSO}_{4} \text {, for } 4 \mathrm{~h} \text { at RT. The } \\
\text { mixture was } \\
\text { centrifugated at } \\
10,000 \text { rpm for } 5 \text { min., } \\
\text { The pellet was washed } \\
\text { with DDW, and ethanol. }\end{array}$ & [382] \\
\hline $12-16 \mathrm{~nm}$ & $\begin{array}{l}\mathrm{DPPH}, \mathrm{NO}^{\bullet}, \mathrm{O}_{2}^{\bullet-} \\
\text { f.r.s.a. }\end{array}$ & Dioscorea bulbifera & ascorbic acid & $\begin{array}{l}\text { The washed and sliced tubers } \\
\text { were dried in a dark place for } \\
3 \text { days. Five grams of the } \\
\text { obtained powder and } 100 \mathrm{~mL} \text { of } \\
\text { SDW were boiled for } 5 \mathrm{~min} \text {. } \\
\text { The extract was filtered }\end{array}$ & $\begin{array}{l}\text { Five milliliters of extract } \\
\text { was shaken at } 150 \mathrm{rpm} \\
\text { in the dark place at } \\
40{ }^{\circ} \mathrm{C} \text { with } 95 \mathrm{~mL} \text { of } \\
1 \mathrm{mM} \mathrm{CuSO} \cdot 5 \mathrm{H}_{2} \mathrm{O} \text {. }\end{array}$ & [429] \\
\hline \multicolumn{7}{|c|}{$\begin{array}{l}\text { Copper oxide }(\mathrm{CuO}) \mathrm{NPs} \\
\text { Absorbance at } 280-360 \mathrm{~nm}\end{array}$} \\
\hline $1.5-20 \mathrm{~nm}$ & - & Lens culinaris & $\begin{array}{l}\text { primary and } \\
\text { secondary amines, } \\
\text { aldehydes, phenols, } \\
\text { proteins }\end{array}$ & $\begin{array}{l}\text { The plant was homogenized in } \\
\text { mortar. After that, } 100 \mathrm{~mL} \text { of } \\
\text { distilled water was added. }\end{array}$ & $\begin{array}{l}1 \mathrm{mM} \mathrm{CuSO}_{4} \text { was stirred } \\
\text { with the filtrated extract } \\
\text { (ratio: } 1: 5, v / v) \text { for } 1 \mathrm{~h} \text { at } \\
37^{\circ} \mathrm{C}(\mathrm{pH} 9) \text {. Then, it } \\
\text { was centrifuged at } \\
12,000 \times g \text { for } 15 \mathrm{~min} . \\
\text { The pellet was washed } \\
\text { with DW, re-suspended } \\
\text { in DW and } \\
\text { ultra-sonicated. }\end{array}$ & [430] \\
\hline $10 \mathrm{~nm}$ & DPPH & Galeopsidis herba & $\begin{array}{l}\text { flavonoids, phenolic } \\
\text { acids,poly- } \\
\text { saccharides }\end{array}$ & $\begin{array}{l}\text { A total of } 4.5 \text { g powdered plants } \\
\text { were mixed with } 300 \mathrm{~mL} \text { DDW, } \\
\text { and stirred for } 50 \mathrm{~min} \text { at } 85^{\circ} \mathrm{C} \text {. } \\
\text { Then, the mixture was filtered. }\end{array}$ & $\begin{array}{l}\text { The extract was mixed } \\
\text { with } \mathrm{Cu}\left(\mathrm{NO}_{3}\right)_{2} \text { in the } \\
\text { proportion: } 90: 1(w / w) \text {, } \\
\text { and vigorously stirred } \\
\text { for } 4 \mathrm{~h} \text { at } 80^{\circ} \mathrm{C} \text {. }\end{array}$ & [431] \\
\hline $\begin{array}{l}\text { Spherical, } \\
\text { agglomerated }\end{array}$ & - & $\begin{array}{l}\text { Terminalia } \\
\text { phanerophlebia }\end{array}$ & - & $\begin{array}{l}\text { Extract from the oven-dried } \\
\text { leaves was prepared from } 2 \mathrm{~g} \text { of } \\
\text { the ground powdered and } \\
150 \mathrm{~mL} \text { deionized water, } \\
\text { ethanol, or acetone. The } \\
\text { extracts were filtered. }\end{array}$ & $\begin{array}{l}\text { Thirty milliliters of } \\
\mathrm{CuSO}_{4} \cdot 5 \mathrm{H}_{2} \mathrm{O}(0.1 \mathrm{M}) \\
\text { was stirred with } 10 \mathrm{~mL} \\
\text { of the plant extract, and } \\
\text { heated at } 90^{\circ} \mathrm{C} \text { for } 5 \mathrm{~h} \text {. } \\
\text { The solution was kept } \\
\text { overnight at RT. The } \\
\mathrm{CuO} \text { NPs were } \\
\text { centrifuged, washed } \\
\text { with DW, dried in } \\
\text { hot air. }\end{array}$ & [432] \\
\hline \multicolumn{7}{|c|}{$\begin{array}{c}\text { Iron (Fe) NPs } \\
\text { Absorbance at } 214 \mathrm{~nm}\end{array}$} \\
\hline $\begin{array}{l}\text { Spherical, } \\
\text { cubic } \\
43-220 \mathrm{~nm}\end{array}$ & DPPH & Amaranthus dubius & $\begin{array}{l}\text { amaranthine, } \\
\text { phenolic } \\
\text { compounds }\end{array}$ & $\begin{array}{l}\text { The leaves were cleaned, } \\
\text { chopped into small pieces. } 20 \mathrm{~g} \\
\text { of leaves were mixed with } \\
100 \mathrm{~mL} \mathrm{DW} \text { and keep at } 50{ }^{\circ} \mathrm{C} \\
\text { for } 45 \mathrm{~min} \text {. The mixture } \\
\text { was filtered. }\end{array}$ & $\begin{array}{l}\text { The leaf extract ( } \mathrm{pH} 6) \\
\text { was added a drop to } \\
0.5 \mathrm{M} \mathrm{FeCl}_{3} \text { with stirring } \\
\text { for } 90 \mathrm{~min} \text {. }\end{array}$ & [433] \\
\hline $20-25 \mathrm{~nm}$ & $\begin{array}{l}\text { DPPH, ABTS, } \\
\mathrm{H}_{2} \mathrm{O}_{2} \text { f.r.s.a. }\end{array}$ & $\begin{array}{l}\text { Asphodelus } \\
\text { aestivus Brot. }\end{array}$ & $\begin{array}{l}\text { phenolic } \\
\text { compounds, poly- } \\
\text { sachharides }\end{array}$ & $\begin{array}{l}\text { The infusion was prepared in a } \\
\text { ratio of } 5 \% \text {. The filtrate was } \\
\text { concentrated using a } \\
\text { vacuum evaporator. }\end{array}$ & $\begin{array}{l}\text { Five milliliters of extract } \\
\text { was mixed with } 5 \mathrm{~mL} \text { of } \\
1 \mathrm{mM} \text { aqueous } \mathrm{FeCl}_{3} \text {. } \\
\text { The mixture was kept at } \\
50-60{ }^{\circ} \mathrm{C} \text { for } 20 \text { min with } \\
\text { shaking. Then, it was } \\
\text { centrifuged at } 5000 \mathrm{rpm} \\
\text { for } 30 \text { min. }\end{array}$ & [434] \\
\hline \multicolumn{7}{|c|}{$\begin{array}{l}\text { Iron oxide (FeO) NPs } \\
\text { Absorbance at } 290 \mathrm{~nm}\end{array}$} \\
\hline $\begin{array}{l}\text { spherical } \\
58-530 \mathrm{~nm}\end{array}$ & DPPH & $\begin{array}{l}\text { Amaranthus } \\
\text { spinosus L. }\end{array}$ & $\begin{array}{l}\text { amaranthine, } \\
\text { compounds with } \\
\text { hydroxyl or } \\
\text { amines groups, } \\
\text { free amino, } \\
\text { carboxylic moieties }\end{array}$ & $\begin{array}{l}\text { Ten grams of fresh leaves were } \\
\text { washed with DW, and chopped } \\
\text { into pieces, and mixed with } \\
50 \mathrm{~mL} \text { water, and keep at } 50^{\circ} \mathrm{C} \\
\text { for } 45 \text { min. The supernatant } \\
\text { was filtered. }\end{array}$ & $\begin{array}{l}\text { The leaf extract }(\mathrm{pH} 6) \\
\text { was added to } 50 \mathrm{~mL} \text { of } \\
0.5 \mathrm{M} \mathrm{FeCl}_{3} \text { stirring at } \\
37 \pm 1{ }^{\circ} \mathrm{C} \text { for } 90 \mathrm{~min} \text {. } \\
\text { The precipitate (FeO } \\
\text { NPs) was washed with } \\
\text { ethanol and dried at } \\
60^{\circ} \mathrm{C} \text { for } 180 \text { min. }\end{array}$ & [383] \\
\hline
\end{tabular}


Table 4. Cont.

\begin{tabular}{|c|c|c|c|c|c|c|}
\hline Shape/Size & $\begin{array}{l}\text { Activity Assay/ } \\
\text { Control }\end{array}$ & $\begin{array}{l}\text { Biological } \\
\text { Material }\end{array}$ & $\begin{array}{l}\text { Effective } \\
\text { Molecules }\end{array}$ & Preparation of Extract & Bio-Synthesis of NPs & Ref. \\
\hline \multicolumn{7}{|c|}{$\begin{array}{l}\text { Nickel oxide (NiO) NPs } \\
\text { Absorbance at } 305 \mathrm{~nm}\end{array}$} \\
\hline $\begin{array}{l}\text { spherical } \\
\text { agglomerated } \\
\text { NPs } \\
20-50 \mathrm{~nm}\end{array}$ & DPPH & stevia leaf broth & $\begin{array}{l}\text { terpenoids, } \\
\text { polyphenols, } \\
\text { proteins, aldoses }\end{array}$ & $\begin{array}{l}\text { To } 5 \mathrm{~g} \text { of dried leaves, } 100 \mathrm{~mL} \\
\text { DW was added and boiled } \\
(2 \mathrm{~min} .) \text {, and finally filtered. }\end{array}$ & $\begin{array}{l}\text { One gram of nickel } \\
\text { acetate in } 200 \mathrm{~mL} \mathrm{DW} \\
\text { was stirred with } 25 \mathrm{~mL} \\
\text { extract for } 2 \mathrm{~h} \text {. The } \\
\text { mixture was then heated } \\
\text { at } 100^{\circ} \mathrm{C} \text {, and then at } \\
500^{\circ} \mathrm{C} \text { for } 2 \mathrm{~h} \text {. }\end{array}$ & [435] \\
\hline $\begin{array}{l}\text { agglomerated } \\
\text { NPs }\end{array}$ & $\begin{array}{l}\text { TAC/phosph- } \\
\text { omolybdenum, } \\
\text { DPPH }\end{array}$ & $\begin{array}{l}\text { Berberis } \\
\text { balochistanica }\end{array}$ & $\begin{array}{l}\text { polyphenols, } \\
\text { carboxylic acids, } \\
\text { alcohols, sulfur } \\
\text { compounds }\end{array}$ & $\begin{array}{l}\text { The material was washed, } \\
\text { oven-dried for } 10 \mathrm{~h} \text { at } 40^{\circ} \mathrm{C} \text {. } \\
20.66 \mathrm{~g} \text { of powder was stirred } \\
\text { with } 200 \mathrm{~mL} \text { of DW for } 12 \mathrm{~h} \text {. } \\
\text { Then, the extract was filtered } \\
\text { and centrifuged at } 3000 \mathrm{rpm} \text { for } \\
30 \mathrm{~min} \text {. }\end{array}$ & $\begin{array}{l}\text { A } 50 \mathrm{~mL} \text { extract was } \\
\text { added drop by drop to } \\
\text { the solution of } \mathrm{NiNO}_{3} \\
(0.3 \mathrm{M}) \text {. The mixture was } \\
\text { heated at } 60^{\circ} \mathrm{C} \text { with } \\
\text { stirred at } 500 \mathrm{rpm} \text { for } \\
3 \mathrm{~h} \text {. }\end{array}$ & [436] \\
\hline \multicolumn{7}{|c|}{$\begin{array}{c}\text { Manganese (Mn) NPs } \\
\text { Absorbance at } 415-417 \mathrm{~nm}\end{array}$} \\
\hline $\begin{array}{l}\text { spherical } \\
\text { granular } \\
57-69 \mathrm{~nm}\end{array}$ & - & $\begin{array}{l}\text { Ctenolepis garcini } \\
\text { (Burm. f.) }\end{array}$ & native proteins & $\begin{array}{l}\text { To } 2 \text { g air-dried sample, } 30 \mathrm{~mL} \\
\text { of SDW was added, and boiled } \\
(2 \mathrm{~min} .) .\end{array}$ & $\begin{array}{l}\text { Five milliliters of the } \\
\text { filtered extract was } \\
\text { added to } 25 \mathrm{~mL} \text { of } 1 \mathrm{mM} \\
\mathrm{KMnO}_{4} \text { solution and } \\
\text { stored in RT for } 24 \mathrm{~h} \text {. }\end{array}$ & [437] \\
\hline \multicolumn{7}{|c|}{$\begin{array}{c}\text { Manganese oxide }(\mathrm{MnO}) \mathrm{NPs} \\
\text { Absorbance at } 460 \mathrm{~nm}\end{array}$} \\
\hline $\begin{array}{l}\text { spherical } \\
80 \pm 0.5 \mathrm{~nm}\end{array}$ & - & Abutilon indicum & - & $\begin{array}{l}\text { Twenty grams of leaves powder } \\
\text { was mixed with } 50 \% \text { methanol. } \\
\text { It was placed on a magnetic hot } \\
\text { plate and underwent stirring } \\
\text { for about } 30 \text { min at } 55^{\circ} \mathrm{C} \text { and } \\
\text { allowed to settle overnight. }\end{array}$ & $\begin{array}{l}\text { One hundred milliliters } \\
\text { of } 0.1 \mathrm{M} \mathrm{MnSO}{ }_{4} \cdot \mathrm{H}_{2} \mathrm{O} \\
\text { was mixed with } 100 \mathrm{~mL} \\
\text { of plant extract. A total } \\
\text { of } 0.1 \mathrm{M} \mathrm{NaOH} \text { solution } \\
\text { was added dropwise to } \\
\text { the beaker with constant } \\
\text { stirring for about } 1 \mathrm{~h} \text { at } \\
\text { pH } 8.0 \text { and } 50^{\circ} \mathrm{C} \text {. }\end{array}$ & [438] \\
\hline \multicolumn{7}{|c|}{$\begin{array}{c}\text { Magnesium Oxide Nanoparticles (MgO) NPs } \\
\text { Absorbance at } 250 \mathrm{~nm}\end{array}$} \\
\hline $\begin{array}{l}\text { Spherical } \\
7-40 \mathrm{~nm}\end{array}$ & - & $\begin{array}{l}\text { Penicillium } \\
\text { chrysogenum }\end{array}$ & $\begin{array}{l}\text { polysaccharides } \\
\text { hydrocarbons, } \\
\text { amines, carboxylate, } \\
\text { amino groups }\end{array}$ & $\begin{array}{l}\text { The fungal strains were } \\
\text { inoculated into MAB, and } \\
\text { incubated for } 5 \text { days at } \\
30 \pm 2{ }^{\circ} \mathrm{C} \text { and shaking state at } \\
150 \mathrm{rpm} \text {. Then, the biomass was } \\
\text { centrifuged and resuspended in } \\
100 \mathrm{~mL} \text { in DDW. }\end{array}$ & $\begin{array}{l}\text { A total of } 76.9 \mathrm{mg} \text { of } \\
\mathrm{Mg}\left(\mathrm{NO}_{3}\right)_{2} \cdot 6 \mathrm{H}_{2} \mathrm{O} \text { was } \\
\text { dissolved in } 10 \mathrm{~mL} \mathrm{DW} \text {, } \\
\text { mixed with } 90 \mathrm{~mL} \text { of } \\
\text { biomass filtrate and } \\
\text { incubated for } 24 \mathrm{~h} \text {. The } \\
\text { white precipitate was } \\
\text { collected and rinsed } \\
\text { with DW, and } \\
\text { oven-dried at } 400{ }^{\circ} \mathrm{C} \text { for } \\
3 \mathrm{~h} \text {. }\end{array}$ & [439] \\
\hline
\end{tabular}

Abbreviations: room temperature (RT); double-distilled water (DDW), tryptic soy broth (TSB), human umbilical vein endothelial cells (HUVEC), starch casein agar medium (SCA), malt extract broth media (MAB), Malt Yeast Extract medium (MYE), sterile double distilled water (SDDW), double distilled water (DDW), sterile distilled water (DW), deionized water (DI), potato dextrose broth (PDB), potato dextrose agar (PDA), International Streptomyces (ISP 2), dichlorofluorescein (DCF), free radical scavenging activity (f.r.s.a).

\subsection{Trends of NPs Modification}

Increasing attention is paid to nanoparticles functionalized by various antioxidants obtained from various natural sources, such as algae, bacteria, fungi, lichens, and plants. It should be emphasized that most authors reported that the functionalized NPs exhibit a few times greater antiradical activity. The effective transport across the cell membrane through pinocytosis and the possibility of targeted localization give rise possibility of NPs utilization also as carriers for antioxidants. In those cases, inert metalcore and antioxidants attached to the nanoparticle surface can exert also independent activity [63]. In 2020, a review on antioxidant functionalized NPs was published [247]. Most papers present the synthesis of gold and silver nanoparticles that are easily functionalized with different small molecules of antioxidants, for instance, gold nanoparticles functionalized with tocopherol [440,441], gold nanoparticles coated with chitosan [442], silver NPs with glutathione [443], or more complex ones like graphite layered $30 \mathrm{~nm}$ cobalt nanomagnets with attached tocopherol derivatives [444]. Konopko et al. [440] and Nie et al. [441] 
prepared and characterized gold nanoparticles (AuNPs) coated with $\alpha$-tocopherol-like residues. Both research groups proved that the assembly of chromanol groups on gold nanoparticles could efficiently enhance the activity of the vitamin E-derived antioxidant. In 2019, Mohd Taib et al. [445] synthesized Au-NPs utilizing water extract of Hibiscus sabdariffa leaves. Owing to the UV-VIS, FTIR, and HPLC analysis, chlorogenic acid was identified as the major antioxidant compound involved in the reduction of $\mathrm{Au}^{3+}$ ions. Moreover, the thiol groups can interact directly with the gold core to form gold-sulfur bonds (Au-S) responsible for the mucoadhesion properties of the synthetized AuNPs [446]. In 2017, Choi et al. [447] described nanoparticles modified by caffeic acid, which was immobilized on the surfaces of micro-dielectric barrier discharge (DBD) plasma-treated $\mathrm{ZnO}$ nanoparticles. Obtained nanoparticles showed strong antioxidant (ABTS), antibacterial activity against Gram-positive bacteria (Staphylococcus aureus), including resistant bacteria such as methicillin-resistant S. aureus, and against Gram-negative bacteria (Escherichia coli). Nanostructural materials such as nanotubes have been described as novel synergistic nano-antioxidants [448], for example, ascorbic acid loaded into the inner lumen of natural halloysite nanotubes [449] or halloysite externally deco-rated with tocopherol-like moieties and containing quercetin inside the nanotube [450]. Many studies have described functionalized silver and gold nanoparticles derived from fungal or bacterial extracts obtained from species Ganoderma lucidium [408-410], Aspergillus versicolor, Cladosporium cladosporioides, Pestalotiopsis microspore [401,403,451], and bacteria Lactobacillus kimchicus [419].

Another promising trend of nanobiotechnology represents the development of nanodrug delivery systems composed of biocompatible and biodegradable polymeric nanomaterials (polylactide-PLA, poly-lactic-co-glycolic acid- PLGA) that are able to encapsulate the therapeutic agent and progressively release it at the target site. Chlorogenic acid entrapped in hybrid materials composed of $\mathrm{SiO}_{2}$ and polyethylene glycol has been identified as a system able to control the overproduction of RNS/ROS [452]. Another example is curcumin encapsulated in a nanocarrier and covered with chitosan. Authors observed a protective effect of chitosan on the antioxidant activity of curcumin [453,454]. While inorganic nanoparticles, especially those with semiconductor properties, have found applications in in vitro diagnostics and imaging, nano-drugs ensure effective biodistribution thanks to the ability to overcome biological barriers. Thus far, many medicinal preparations in the form of nanoparticles have been developed, belonging to different classes of NPs (polymeric, inorganic, and lipid-based), such as polymer-drug conjugate, protein-drug conjugate, polymer-protein conjugate, antibody-drug conjugate, dendimeric drug, polymeric micelle, polymersome, liposome, PEGylated liposome, organic/inorganic colloid, quantum dot, Si-NPs, Au-NPs, and INPs. Extensive reviews on this subject have already been published [455-458]; unfortunately, it is beyond the scope of the current study.

Interesting nano-formulas are also doubly hydrophilic self-assembling block copolymers (DHBC), which in recent years have aroused more and more interest not only for the production of nanoparticles, but also as controlled drug distribution systems. A valuable review on DHBC was published in 2020 by Jundi et al. [459].

\section{Concluding Remarks and Future Perspectives}

Considering the key role of antioxidants to treat oxidative diseases, the development of reliable antioxidant activity assays of different products with high antioxidant content, as potential drugs or supplements, is needed. Several analytical techniques can be applied for this purpose such as spectroscopic, chromatographic, and electrochemical ones. At the beginning of the 21st century, antioxidant assays based on NPs were developed. The use of NPs as optical or electrochemical probes appears to be a very promising approach; however, this technique has still been scarcely followed. Over 5 years of research on the NPs-based method has resulted in a negligible number of publications, which illustrates the fact that in the PubMed database, the phrases "antioxidant capacity", "nanoparticles", and "plant extracts" are associated with no more than 70 scientific papers. One should emphasize that performing the comparative analysis of antioxidant potentials on the 
basis of results published by different research groups is very difficult. The antioxidant potential of natural products, and even single chemicals, depends on many factors such as conditions of samples collections, as well as the extracts preparation method and the way of expressing results.

On the other hand, the plant extracts rich in antioxidants that act as both reducing and stabilizing agents appear to be useful for creating metallic nanoparticles. Green synthesis surpasses classical methods, providing such benefits as low-cost, environmentally friendly strategies not requiring high pressure, energy, temperature, or external toxic chemical agents. Furthermore, green synthesis ensures the formation of nanoparticles free of toxic contaminants, which makes them suitable in therapeutic applications such as antimicrobial agents in bandages, applications in targeted drug delivery, or clinical diagnostics as contrast agents (MRI-Magnetic Resonance Imaging). The popularity of green nanoparticle synthesis toward bio and medical applications is reflected in the number of around 5000 publications that have appeared in the PubMed database in the last five years.

A promising trend that has been developing dynamically in recent years is the synthesis of antioxidant functionalized nanoparticles. Such modification improves the bioavailability of antioxidants providing the benefits of biocompatibility, high stability, and targeted delivery.

Author Contributions: J.F. and W.F. wrote—original draft preparation, J.B. and W.F. collected and reviewed the data; W.F. edited the paper and prepared visualization of the paper., J.F. and R.M. wrote-review and edited, R.M. was responsible for supervision, R.M. was responsible for project administration, and J.F., J.B., and R.M. dealt with funding acquisition. All authors have read and agreed to the published version of the manuscript.

Funding: This research received no external funding.

Institutional Review Board Statement: Not applicable.

Informed Consent Statement: Not applicable.

Conflicts of Interest: The authors declare no conflict of interest.

\section{References}

1. Choi, H.J.; Kim, J.H.; Lee, C.H.; Ahn, Y.J.; Song, J.H.; Baek, S.H.; Kwon, D.H. Antiviral activity of quercetin 7-rhamnoside against porcine epidemic diarrhea virus. Antiviral Res. 2009, 81, 77-81. [CrossRef] [PubMed]

2. Song, J.H.; Shim, J.K.; Choi, H.J. Quercetin 7-rhamnoside reduces porcine epidemic diarrhea virus replication via independent pathway of viral induced reactive oxygen species. Virol. J. 2011, 8, 460. [CrossRef] [PubMed]

3. Liang, W.; He, L.; Ning, P.; Lin, J.; Li, H.; Lin, Z.; Kang, K.; Zhang, Y. (+)-Catechin inhibition of transmissible gastroenteritis coronavirus in swine testicular cells is involved its antioxidation. Res. Vet. Sci. 2015, 103, 28-33. [CrossRef]

4. Diniz, L.R.L.; Bezerra Filho, C.D.S.M.; Fielding, B.C.; de Sousa, D.P. Natural Antioxidants: A Review of Studies on Human and Animal Coronavirus. Oxid. Med. Cell. Longev. 2020, 1-14. [CrossRef] [PubMed]

5. Delgado-Roche, L.; Mesta, F. Oxidative Stress as Key Player in Severe Acute Respiratory Syndrome Coronavirus (SARS-CoV) Infection. Arch. Med. Res. 2020, 51, 384-387. [CrossRef]

6. Jo, S.; Kim, S.; Shin, D.H.; Kim, M.S. Inhibition of SARS-CoV 3CL protease by flavonoids. J. Enzyme Inhib. Med. Chem. 2020, 35, 145-151. [CrossRef]

7. Chen, L.; Li, J.; Luo, C.; Liu, H.; Xu, W.; Chen, G.; Liew, O.W.; Zhu, W.; Puah, C.M.; Shen, X.; et al. Binding interaction of quercetin-3-beta-galactoside and its synthetic derivatives with SARS-CoV 3CL(pro): Structure-activity relationship studies reveal salient pharmacophore features. Bioorg. Med. Chem. 2006, 14, 8295-8306. [CrossRef] [PubMed]

8. Ryu, Y.B.; Jeong, H.J.; Kim, J.H.; Kim, Y.M.; Park, J.Y.; Kim, D.; Nguyen, T.T.; Park, S.J.; Chang, J.S.; Park, K.H.; et al. Biflavonoids from Torreya nucifera displaying SARS-CoV 3CL(pro) inhibition. Bioorg. Med. Chem. 2010, 18, 7940-7947. [CrossRef]

9. Kim, D.W.; Seo, K.H.; Curtis-Long, M.J.; Oh, K.Y.; Oh, J.W.; Cho, J.K.; Lee, K.H.; Park, K.H. Phenolic phytochemical displaying SARS-CoV papain-like protease inhibition from the seeds of Psoralea corylifolia. J. Enzyme Inhib. Med. Chem. 2014, 29, 59-63. [CrossRef]

10. Yu, M.S.; Lee, J.; Lee, J.M.; Kim, Y.; Chin, Y.W.; Jee, J.G.; Keum, Y.S.; Jeong, Y.J. Identification of myricetin and scutellarein as novel chemical inhibitors of the SARS coronavirus helicase, nsP13. Bioorg. Med. Chem. Lett. 2012, 22, 4049-4054. [CrossRef]

11. Cárdenas-Rodríguez, N.; Bandala, C.; Vanoye-Carlo, A.; Ignacio-Mejía, I.; Gómez-Manzo, S.; Hernández-Cruz, E.Y.; PedrazaChaverri, J.; Carmona-Aparicio, L.; Hernández-Ochoa, B. Use of Antioxidants for the Neuro-Therapeutic Management of COVID-19. Antioxidants 2021, 10, 971. [CrossRef] 
12. Forman, H.J.; Zhang, H. Targeting oxidative stress in disease: Promise and limitations of antioxidant therapy. Nat. Rev. Drug Discov. 2021. [CrossRef]

13. Forman, H.J.; Davies, K.J.; Ursini, F. How do nutritional antioxidants really work: Nucleophilic tone and para-hormesis versus free radical scavenging in vivo. Free Radic. Biol. Med. 2014, 66, 24-35. [CrossRef]

14. Sies, H. Strategies of antioxidant defense. Eur. J. Biochem. 1993, 215, 213-219. [CrossRef]

15. Bansal, S.; Choudhary, S.; Sharma, M.; Kumar, S.S.; Lohan, S.; Bhardwaj, V.; Syan, N.; Jyoti, S. Tea: A native source of antimicrobial agents. Food Res. Int. 2013, 53, 568-584. [CrossRef]

16. Jiang, J.; Xiong, Y.L. Natural antioxidants as food and feed additives to promote health benefits and quality of meat products: A review. Meat Sci. 2016, 120, 107-117. [CrossRef] [PubMed]

17. Lü, J.-M.; Lin, P.H.; Yao, Q.; Chen, C. Chemical and molecular mechanisms of antioxidants: Experimental approaches and model systems. J. Cell. Mol. Med. 2009, 14, 840-860. [CrossRef]

18. Cetin-Karaca, H.; Newman, M.C. Antimicrobial efficacy of plant phenolic compounds against Salmonella and Escherichia coli. Food Biosci. 2015, 11, 8-16. [CrossRef]

19. Caleja, C.; Barros, L.; Antonio, A.L.; Ćirić, A.; Barreira, J.C.; Sokovic, M.; Oliveira, M.B.P.; Santos-Buelga, C.; Ferreira, I.C. Development of a functional dairy food: Exploring bioactive and preservation effects of chamomile (Matricaria recutita L.). J. Funct. Foods. 2015, 16, 114-124. [CrossRef]

20. De Dicastillo, C.L.; Rodríguez, F.; Guarda, A.; Galotto, M.J. Antioxidant films based on cross-linked methyl cellulose and native Chilean berry for food packaging applications. Carbohydr. Polym. 2016, 136, 1052-1060. [CrossRef]

21. Galanakis, C.M.; Tsatalas, P.; Charalambous, Z.; Galanakis, I.M.; Charalambous, Z. Polyphenols recovered from olive mill wastewater as natural preservatives in extra virgin olive oils and refined olive kernel oils. Environ. Technol. Innov. 2018, 10, 62-70. [CrossRef]

22. Bodoira, R.M.; Penci, M.C.; Ribotta, P.D.; Martinez, M.L. Chia (Salvia hispanica L.) oil stability: Study of the effect of natural antioxidants. LWT 2017, 75, 107-113. [CrossRef]

23. Özcan, M.M.; Arslan, D. Antioxidant effect of essential oils of rosemary, clove and cinnamon on hazelnut and poppy oils. Food Chem. 2011, 129, 171-174. [CrossRef]

24. Wibowo, S.; Vervoort, L.; Tomic, J.; Santiago, J.S.; Lemmens, L.; Panozzo, A.; Grauwet, T.; Hendrickx, M.; Van Loey, A. Colour and carotenoid changes of pasteurised orange juice during storage. Food Chem. 2015, 171, 330-340. [CrossRef]

25. Oswell, N.J.; Thippareddi, H.; Pegg, R.B. Practical use of natural antioxidants in meat products in the U.S.: A review. Meat Sci. 2018, 145, 469-479. [CrossRef] [PubMed]

26. Das, A.K.; Rajkumar, V.; Nanda, P.K.; Chauhan, P.; Pradhan, S.R.; Biswas, S. Antioxidant Efficacy of Litchi (Litchi chinensis Sonn.) Pericarp Extract in Sheep Meat Nuggets. Antioxidants 2016, 5, 16. [CrossRef]

27. Caleja, C.; Barros, L.; Antonio, A.L.; Oliveira, M.B.P.; Ferreira, I.C. A comparative study between natural and synthetic antioxidants: Evaluation of their performance after incorporation into biscuits. Food Chem. 2017, 216, 342-346. [CrossRef]

28. Embuscado, M.E. Spices and herbs: Natural sources of antioxidants-A mini review. J. Funct. Foods. 2015, 18, 811-819. [CrossRef]

29. Lourenço, S.C.; Moldão-Martins, M.; Alves, V.D. Antioxidants of Natural Plant Origins: From Sources to Food Industry Applications. Molecules 2019, 24, 4132. [CrossRef] [PubMed]

30. Freitas, A.; Moldão-Martins, M.; Costa, H.S.; Albuquerque, T.G.; Valente, A.; Sanches-Silva, A. Effect of UV-C radiation on bioactive compounds of pineapple (Ananas comosus L. Merr.) by-products. J. Sci. Food Agric. 2015, 95, 44-52. [CrossRef]

31. Panić, M.; Stojković, M.R.; Kraljić, K.; Škevin, D.; Redovniković, I.R.; Srček, V.G.; Radošević, K. Ready-to-use green polyphenolic extracts from food by-products. Food Chem. 2019, 283, 628-636. [CrossRef]

32. Corrêa-Filho, L.C.; Lourenço, S.C.; Duarte, D.F.; Moldão-Martins, M.; Alves, V.D. Microencapsulation of Tomato (Solanum lycopersicum L.) Pomace Ethanolic Extract by Spray Drying: Optimization of Process Conditions. Appl. Sci. 2019, 9, 612. [CrossRef]

33. Brezoiu, A.-M.; Matei, C.; Deaconu, M.; Stanciuc, A.-M.; Trifan, A.; Gaspar-Pintiliescu, A.; Berger, D. Polyphenols extract from grape pomace. Characterization and valorisation through encapsulation into mesoporous silica-type matrices. Food Chem. Toxicol. 2019, 133, 110787. [CrossRef]

34. Da Silva, D.I.; Nogueira, G.D.; Duzzioni, A.G.; Barrozo, M.A. Changes of antioxidant constituents in pineapple (Ananas comosus) residue during drying process. Ind. Crop. Prod. 2013, 50, 557-562. [CrossRef]

35. Goodsell, D.S. Bionanomedicine in Action. In Bionanotechnology: Lessons from Nature; John Wiley \& Sons, Inc.: Hoboken, NJ, USA, 2004.

36. Chrząszcz, M.; Krzemińska, B.; Celiński, R.; Szewczyk, K. Phenolic Composition and Antioxidant Activity of Plants Belonging to the Cephalaria (Caprifoliaceae) Genus. Plants 2021, 10, 952. [CrossRef]

37. Rani, A.; Saini, K.C.; Bast, F.; Mehariya, S.; Bhatia, S.K.; Lavecchia, R.; Zuorro, A. Microorganisms: A Potential Source of Bioactive Molecules for Antioxidant Applications. Molecules 2021, 26, 1142. [CrossRef] [PubMed]

38. Gülçin, İ. Antioxidant activity of food constituents: An overview. Arch. Toxicol. 2011, 86, 345-391. [CrossRef]

39. Marcelino, G.; Machate, D.J.; Freitas, K.d.C.; Hiane, P.A.; Maldonade, I.R.; Pott, A.; Asato, M.A.; Candido, C.J.; Guimarães, R.d.C.A. $\beta$-Carotene: Preventive Role for Type 2 Diabetes Mellitus and Obesity: A Review. Molecules 2020, 25, 5803. [CrossRef] [PubMed]

40. Scarano, A.; Chieppa, M.; Santino, A. Plant Polyphenols-Biofortified Foods as a Novel Tool for the Prevention of Human Gut Diseases. Antioxidants 2020, 9, 1225. [CrossRef] 
41. Talib, W.H.; AL-Ataby, I.A.; Mahmod, A.I.; Jawarneh, S.; Al Kury, L.T.; AL-Yasari, I.H. The Impact of Herbal Infusion Consumption on Oxidative Stress and Cancer: The Good, the Bad, the Misunderstood. Molecules 2020, 25, 4207. [CrossRef] [PubMed]

42. Mittal, A.K.; Chisti, Y.; Banerjee, U.C. Synthesis of metallic nanoparticles using plant extracts. Biotechnol. Adv. 2013, 31, 346-356. [CrossRef] [PubMed]

43. Cheeseman, K.H.; Slater, T.F. An introduction to free radicals chemistry. Br. Med. Bull. 1993, 49, 481-493. [CrossRef] [PubMed]

44. Liu, T.; Stern, A.; Roberts, L.J.; Morrow, J.D. The isoprostanes: Novel prostanglandin-like products of the free radical catalyzed peroxidation of arachidonic acid. J. Biomed. Sci. 1999, 6, 226-235. [CrossRef] [PubMed]

45. Beers, R.F.; Sizer, I.W. A spectrophotometric method for measuring the breakdown of hydrogen peroxide by catalase. J. Biol. Chem. 1952, 195, 133-140. [CrossRef]

46. Apak, R.; Özyürek, M.; Güçlü, K.; Çapanoğlu, E. Antioxidant Activity/Capacity Measurement. 1. Classification, Physicochemical Principles, Mechanisms, and Electron Transfer (ET)-Based Assays. J. Agric. Food Chem. 2016, 64, 997-1027. [CrossRef]

47. Graves, D.B. The emerging role of reactive oxygen and nitrogen species in redox biology and some implications for plasma applications to medicine and biology. J. Phys. D Appl. Phys. 2012, 45, 263001. [CrossRef]

48. Poljsak, B.; Šuput, D.; Milisav, I. Achieving the Balance between ROS and Antioxidants: When to Use the Synthetic Antioxidants. Oxidative Med. Cell. Longev. 2013, 1-11. [CrossRef]

49. Bagchi, K.; Puri, S. Free radicals and antioxidants in health and disease. East Mediterr. Health J. 1998, 4, 350-360.

50. Hollman, P.C.; Cassidy, A.; Comte, B.; Heinonen, M.; Richelle, M.; Richling, E.; Serafini, M.; Scalbert, A.; Sies, H.; Vidry, S. The biological relevance of direct antioxidant effects of polyphenols for cardiovascular health in humans is not established. J. Nutr. 2011, 141, 989S-1009S. [CrossRef]

51. Roediger, B.; Armati, P.J. Oxidative stress induces axonal beading in cultured human brain tissue. Neurobiol. Dis. 2003, 13, 222-229. [CrossRef]

52. Young, I.S.; Woodside, J.V. Antioxidants in health and disease. J. Clin. Pathol. 2001, 54, 176-186. [CrossRef]

53. Pisoschi, A.M.; Pop, A. The role of antioxidants in the chemistry of oxidative stress: A review. Eur. J. Med. Chem. 2015, 97, 55-74. [CrossRef]

54. Singh, U.; Jialal, I. Oxidative stress and atherosclerosis. Pathophysiology 2006, 13, 129-142. [CrossRef] [PubMed]

55. Rao, A.L.; Bharani, M.; Pallavi, V. Role of antioxidants and free radicals in health and disease. Adv. Pharmacol. Toxicol. 2006, 7 , 29-38.

56. Stefanis, L.; Burke, R.E.; Greene, L.A. Apoptosis in neurodegenerative disorders. Curr. Opin. Neurol. 1997, 10, 299-305. [CrossRef]

57. Lobo, V.; Patil, A.; Phatak, A.; Chandra, N. Free radicals, antioxidants and functional foods: Impact on human health. Pharmacogn Rev. 2010, 4, 118-126. [CrossRef] [PubMed]

58. Sas, K.; Robotka, H.; Toldi, J.; Vécsei, L. Mitochondria, metabolic disturbances, oxidative stress and the kynurenine system, with focus on neurodegenerative disorders. J. Neurol. Sci. 2007, 257, 221-239. [CrossRef]

59. Beal, M.F. Therapeutic approaches to mitochondrial dysfunction in Parkinson's disease. Parkinsonism Relat. Disord. 2009, 15, S189-S194. [CrossRef]

60. Chong, Z.Z.; Li, F.; Maiese, K. Oxidative stress in the brain: Novel cellular targets that govern survival during neurodegenerative disease. Prog. Neurobiol. 2005, 75, 207-246. [CrossRef]

61. Halliwell, B. Oxidative stress and neurodegeneration: Where are we now? J. Neurochem. 2006, 97, 1634-1658. [CrossRef]

62. Sies, H. Oxidative stress: From basic research to clinical application. Am. J. Med. 1991, 91, 31S-38S. [CrossRef]

63. Brown, G.C.; Borutaite, V. Nitric oxide, mitochondria, and cell death. IUBMB Life 2001, 52, 189-195. [CrossRef] [PubMed]

64. Aruoma, O.I. Nutrition and health aspects of free radicals and antioxidants. Food Chem. Toxicol. 1994, 32, 671-683. [CrossRef]

65. McCord, J.M. The evolution of free radicals and oxidative stress. Am. J. Med. 2000, 108, 652-659. [CrossRef]

66. Fang, Y.Z.; Yang, S.; Wu, G. Free radicals, antioxidants, and nutrition. Nutrition 2002, 18, 872-879. [CrossRef]

67. Knight, J.A. Free radicals: Their history and current status in aging and disease. Ann. Clin. Lab. Sci. 1998, 28, 331-346.

68. Jacob, R.A. Three eras of vitamin C discovery. Subcell. Biochem. 1996, 25, 1-16.

69. Moreau, D. Comptes Rendus des Séances et Mémoires de la Société de Biologie; Au Bureau de la Gazette médicale: Paris, France, 1922; Volume 86, p. 321.

70. Mattill, H.A. Antioxidants. Annu. Rev. Biochem. 1947, 16, 177-192. [CrossRef]

71. German, J.B. Food processing and lipid oxidation. Adv. Exp. Med. Biol. 1999, 459, 23-50. [CrossRef]

72. Sies, H. Oxidative stress: Oxidants and antioxidants. Exp. Physiol. 1997, 82, 291-295. [CrossRef]

73. Shi, H.; Noguchi, N.; Niki, E. Comparative study on dynamics of antioxidative action of alpha-tocopheryl hydroquinone, ubiquinol, and alpha-tocopherol against lipid peroxidation. Free Radic. Biol. Med. 1999, 27, 334-346. [CrossRef]

74. Weiss, J.F.; Landauer, M.R. Protection against ionizing radiation by antioxidant nutrients and phytochemicals. Toxicology 2003, 189, 1-20. [CrossRef]

75. Blasko, G.; Cordell, G.A. Recent developments in chemistry of plant derived anticancer agents. In Economic and Medicinal Plant Research; Wagner, H., Hiroshi, H., Farnsworth, N.R., Eds.; Academic Press: New York, NY, USA, 1998.

76. Decramer, M.; Rutten-van Mölken, M.; Dekhuijzen, P.N.; Troosters, T.; van Herwaarden, C.; Pellegrino, R.; van Schayck, C.P.; Olivieri, D.; Del Donno, M.; De Backer, W.; et al. Effects of N-acetylcysteine on outcomes in chronic obstructive pulmonary disease (Bronchitis Randomized on NAC Cost-Utility Study, BRONCUS): A randomised placebo-controlled trial. Lancet 2005, 365, 1552-1560. [CrossRef] 
77. Bast, A. Antioxidant pharmacotherapy. Drug News Perspect. 1994, 7, 465-472.

78. Rahbar Saadat, Y.; Yari Khosroushahi, A.; Pourghassem Gargari, B. A comprehensive review of anticancer, immunomodulatory and health beneficial effects of the lactic acid bacteria exopolysaccharides. Carbohydr. Polym. 2019, 217, 79-89. [CrossRef]

79. Chandra, P.; Sharma, R.K.; Arora, D.S. Antioxidant compounds from microbial sources: A review. Food Res. Int. 2020, $129,108849$. [CrossRef] [PubMed]

80. Yang, M.-H.; Lin, H.-J.; Choong, Y.-M. A rapid gas chromatographic method for direct determination of BHA, BHT and TBHQ in edible oils and fats. Food Res. Int. 2002, 35, 627-633. [CrossRef]

81. Bendary, E.; Francis, R.R.; Ali, H.M.G.; Sarwat, M.I.; El Hady, S. Antioxidant and structure-activity relationships (SARs) of some phenolic and anilines compounds. Ann. Agric. Sci. 2013, 58, 173-181. [CrossRef]

82. Madhavi, D.L.; Deshpande, S.S.; Salunkhe, D.K. Introduction. In Food Antioxidants: Technological, Toxicological, and Health Perspectives; Madhavi, D.L., Deshpande, S.S., Salunkhe, D.K., Eds.; Dekker: New York, NY, USA, 1996; pp. 1-4.

83. Craft, B.D.; Kerrihard, A.L.; Amarowicz, R.; Pegg, R.B. Phenol-based antioxidants and the in vitro methods used for their assessment. Compr. Rev. Food Sci. Food Saf. 2012, 11, 148-173. [CrossRef]

84. Amarowicz, R.; Pegg, R.B. Natural antioxidants of plant origin. Adv. Food Nutr. Res. 2019, 90, 1-81. [CrossRef]

85. Weseler, A.R.; Bast, A. Oxidative stress and vascular function: Implications for pharmacologic treatments. Curr. Hypertens. Rep. 2010, 12, 154-161. [CrossRef] [PubMed]

86. Bast, A.; Haenen, G.R. Ten misconceptions about antioxidants. Trends Pharmacol. Sci. 2013, 34, 430-436. [CrossRef]

87. Reuland, D.J.; McCord, J.M.; Hamilton, K.L. The role of Nrf2 in the attenuation of cardiovascular disease. Exerc. Sport Sci. Rev. 2013, 41, 162-168. [CrossRef]

88. Anson, N.M.; Selinheimo, E.; Havenaar, R.; Aura, A.M.; Mattila, I.; Lehtinen, P.; Bast, A.; Poutanen, K.; Haenen, G.R. Bioprocessing of wheat bran improves in vitro bioaccessibility and colonic metabolism of phenolic compounds. J. Agric. Food Chem. 2009, 57, 6148-6155. [CrossRef]

89. Bjelakovic, G.; Nikolova, D.; Gluud, L.L.; Simonetti, R.G.; Gluud, C. Mortality in randomized trials of antioxidant supplements for primary and secondary prevention: Systematic review and meta-analysis. JAMA 2007, 297, 842-857. [CrossRef]

90. Biesalski, H.K.; Grune, T.; Tinz, J.; Zöllner, I.; Blumberg, J.B. Reexamination of a meta-analysis of the effect of antioxidant supplementation on mortality and health in randomized trials. Nutrients 2010, 2, 929-949. [CrossRef] [PubMed]

91. Stampfer, M.J.; Hennekens, C.H.; Manson, J.E.; Colditz, G.A.; Rosner, B.; Willett, W.C. Vitamin E consumption and the risk of coronary disease in women. N. Engl. J. Med. 1993, 328, 1444-1449. [CrossRef]

92. Vivekananthan, D.P.; Penn, M.S.; Sapp, S.K.; Hsu, A.; Topol, E.J. Use of antioxidant vitamins for the prevention of cardiovascular disease: Meta-analysis of randomised trials. Lancet 2003, 361, 2017-2023. [CrossRef]

93. Eidelman, R.S.; Hollar, D.; Hebert, P.R.; Lamas, G.A.; Hennekens, C.H. Randomized trials of vitamin E in the treatment and prevention of cardiovascular disease. Arch. Intern. Med. 2004, 164, 1552-1556. [CrossRef]

94. Halliwell, B. The antioxidant paradox. Lancet 2000, 355, 1179-1180. [CrossRef]

95. Schürks, M.; Glynn, R.J.; Rist, P.M.; Tzourio, C.; Kurth, T. Effects of vitamin E on stroke subtypes: Meta-analysis of randomised controlled trials. BMJ 2010, 341, c5702. [CrossRef]

96. Watson, J. Oxidants, antioxidants and the current incurability of metastatic cancers. Open Biol. 2013, 3, 120144. [CrossRef]

97. Alpha-Tocopherol Beta Carotene Cancer Prevention Study Group. The effect of vitamin E and beta carotene on the incidence of lung cancer and other cancers in male smokers. N. Engl. J. Med. 1994, 330, 1029-1035. [CrossRef]

98. Pauling, L. Vitamin C and Common Cold. JAMA 1971, 216, 332. [CrossRef]

99. Bast, A.; Haenen, G.R.; Doelman, C.J. Oxidants and antioxidants: State of the art. Am. J. Med. 1991, 91, 2S-13S. [CrossRef]

100. Hrelia, S.; Angeloni, C. New Mechanisms of Action of Natural Antioxidants in Health and Disease. Antioxidants 2020, 9 , 344. [CrossRef]

101. Lunec, J.; Griffits, H.R. Measuring In Vivo Oxidative Damage; John Willey and Sons: New York, NY, USA, 2000.

102. Poljsak, B.; Jamik, P. Methodology for oxidative state detection in biological systems. In Handbook of Free Radicals: Formation, Types and Effects; Cell Biology Research Progress Series; Kozyrev, D., Slutsky, V., Eds.; Nova Science: New York, NY, USA, 2010.

103. Argüelles, S.; Gómez, A.; Machado, A.; Ayala, A. A preliminary analysis of within-subject variation in human serum oxidative stress parameters as a function of time. Rejuvenation Res. 2007, 10, 621-636. [CrossRef]

104. Sahnoun, Z.; Jamoussi, K.; Zeghal, K.M. Free radicals and antioxidants: Human physiology, pathology and therapeutic aspects. Therapie 1997, 52, 251-270. [PubMed]

105. Bunaciu, A.A.; Danet, A.F.; Fleschin, S..; Aboul-Enein, H.Y. Recent Applications for in Vitro Antioxidant Activity Assay. Crit. Rev. Anal. Chem. 2016, 46, 389-399. [CrossRef] [PubMed]

106. Huang, D.; Ou, B.; Prior, R.L. The chemistry behind antioxidant capacity assays. J. Agric. Food Chem. 2005, 53, 1841-1856. [CrossRef] [PubMed]

107. Pérez-Jiménez, J.; Arranz, S.; Tabernero, M.; Díaz- Rubio, M.E.; Serrano, J.; Goñi, I.; Saura-Calixto, F. Updated methodology to determine antioxidant capacity in plant foods, oils and beverages: Extraction, measurement and expression of results. Food Res. Int. 2008, 41, 274-285. [CrossRef]

108. Niki, E.; Noguchi, N. Evaluation of antioxidant capacity. What capacity is being measured by which method? IUBMB Life 2000, 50, 323-329. [CrossRef] 
109. Magalhães, L.M.; Segundo, M.A.; Reis, S.; Lima, J.L. Methodological aspects about in vitro evaluation of antioxidant properties. Anal. Chim. Acta 2008, 613,1-19. [CrossRef]

110. Bartosz, G. Total antioxidant capacity. In Advances in Clinical Chemistry, 1st ed.; Spiegel, H.E., Ed.; Academic Press: New York, NY, USA, 2003; Volume 37, pp. 219-292.

111. Leopoldini, M.; Marino, T.; Russo, N.; Toscano, M. Antioxidant properties of phenolic compounds: H-atom versus electron transfer mechanism. J. Phys. Chem. A 2004, 108, 4916-4922. [CrossRef]

112. Wright, J.S.; Johnson, E.R.; DiLabio, G.A. Predicting the activity of phenolic antioxidants: Theoretical method, analysis of substituent effects, and application to major families of antioxidants. J. Am. Chem. Soc. 2001, 123, 1173-1183. [CrossRef]

113. Noipa, T.; Srijaranai, S.; Tuntulani, T.; Ngeontae, W. New approach for evaluation of the antioxidant capacity based on scavenging DPPH free radical in micelle systems. Food Res. Int. 2011, 44, 798-806. [CrossRef]

114. Boudier, A.; Tournebize, J.; Bartosz, G.; El Hani, S.; Bengueddour, R.; Sapin-Minet, A.; Leroy, P. High performance liquid chromatographic method to evaluate the hydrogen atom transfer during reaction between 1,1-diphenyl-2-picryl-hydrazyl radical and antioxidants. Anal. Chim. Acta 2012, 711, 97-106. [CrossRef] [PubMed]

115. Shahidi, F.; Ambigaipalan, P. Phenolics and polyphenolics in foods, beverages and spices: Antioxidant activity and health effects-A review. J. Funct. Foods 2015, 18, 820-897. [CrossRef]

116. Shahidi, F.; Zhong, Y. Measurement of antioxidant activity. J. Funct. Foods 2015, 18, 757-781. [CrossRef]

117. Scampicchio, M.; Wang, J.; Blasco, A.J.; Sanchez Arribas, A.; Mannino, S.; Escarpa, A. Nanoparticle-based assays of antioxidant activity. Anal. Chem. 2006, 78, 2060-2063. [CrossRef]

118. Özyürek, M.; Güngör, N.; Baki, S.; Güçlü, K.; Apak, R. Development of a Silver Nanoparticle-Based Method for the Antioxidant Capacity Measurement of Polyphenols. Anal. Chem. 2012, 84, 8052-8059. [CrossRef]

119. Antolovich, M.; Prenzler, P.D.; Patsalides, E.; McDonald, S.; Robards, K. Methods for testing antioxidant activity. Analyst 2002, 127, 183-198. [CrossRef]

120. Arnao, M.B. Some methodological problems in the determination of antioxidant activity using chromogen radicals: A practical case. Trends Food Sci. Technol. 2000, 11, 419-421. [CrossRef]

121. Iveković, D.; Milardović, S.; Roboz, M.; Grabarić, B.S. Evaluation of the antioxidant activity by flow injection analysis method with electrochemically generated ABTS radical cation. Analyst 2005, 130, 708. [CrossRef] [PubMed]

122. Apak, R.; Güçlü, K.; Ozyürek, M.; Karademir, S.E. Novel total antioxidant capacity index for dietary polyphenols and vitamins C and E, using their cupric ion reducing capability in the presence of neocuproine: CUPRAC method. J. Agric. Food Chem. 2004, 52, 7970-7981. [CrossRef]

123. Mannino, S.; Brenna, O.; Buratti, S.; Cosio, M.S. A New Method for the Evaluation of the "Antioxidant Power" of Wines. Electroanalysis 1998, 10, 908-912. [CrossRef]

124. Amorati, R.; Valgimigli, L. Methods To Measure the Antioxidant Activity of Phytochemicals and Plant Extracts. J. Agric. Food Chem. 2018, 66, 3324-3329. [CrossRef] [PubMed]

125. Ordoudi, S.A.; Tsimidou, M.Z. Crocin bleaching assay step by step: Observations and suggestions for an alternative validated protocol. J. Agric. Food Chem. 2006, 54, 1663-1671. [CrossRef] [PubMed]

126. Prieto, M.A.; Vázquez, J.A.; Murado, M.A. Crocin bleaching antioxidant assay revisited: Application to microplate to analyse antioxidant and pro-oxidant activities. Food Chem. 2015, 167, 299-310. [CrossRef]

127. Lussignoli, S.; Fraccaroli, M.; Andrioli, G.; Brocco, G.; Bellavite, P. A microplate-based colorimetric assay of the total peroxyl radical trapping capability of human plasma. Anal. Biochem. 1999, 269, 38-44. [CrossRef]

128. Gupta, D. Methods for Determination of Antioxidant Capacity: A Review. Int. J. Pharm. Sci. Res. 2015, 6, 546-566. [CrossRef]

129. Pisoschi, A.M.; Negulescu, G.P. Methods for Total Antioxidant Activity Determination: A Review. Biochem. Anal. Biochem. 2011, 1, 106. [CrossRef]

130. Ndhlala, A.R.; Moyo, M.; Van Staden, J. Natural antioxidants: Fascinating or mythical biomolecules? Molecules 2010, 15, 6905-6930. [CrossRef]

131. Kaur, I.P.; Geetha, T. Screening methods for antioxidants-a review. Mini Rev. Med. Chem. 2006, 6, 305-312. [CrossRef]

132. Christodouleas, D.; Fotakis, C.; Papadopoulos, K.; Dimotikali, D.; Calokerinos, A.C. Luminescent Methods in the Analysis of Untreated Edible Oils: A Review. Anal. Lett. 2012, 45, 625-641. [CrossRef]

133. Gámiz-Gracia, L.; García-Campaña, A.M.; Huertas-Pérez, J.F.; Lara, F.J. Chemiluminescence detection in liquid chromatography: Applications to clinical, pharmaceutical, environmental and food analysis-A review. Anal. Chim. Acta 2009, 640, 7-28. [CrossRef] [PubMed]

134. Popov, I.; Lewin, G. Antioxidative homeostasis: Characterization by means of chemiluminescent technique. Methods Enzymol. 1999, 300, 437-456. [CrossRef] [PubMed]

135. Robak, J.; Gryglewski, R.J. Flavonoids are scavengers of superoxide anions. Biochem. Pharmacol. 1988, 37, 837-841. [CrossRef]

136. Apak, R.; Güçlü, K.; Ozyürek, M.; Karademir, S.E.; Altun, M. Total antioxidant capacity assay of human serum using copper(II)neocuproine as chromogenic oxidant: The CUPRAC method. Free Radic. Res. 2005, 39, 949-961. [CrossRef] [PubMed]

137. Ozyurt, D.; Demirata, B.; Apak, R. Determination of total antioxidant capacity by a new spectrophotometric method based on Ce(IV) reducing capacity measurement. Talanta 2007, 71, 1155-1165. [CrossRef] [PubMed]

138. Ozyurt, D.; Demirata, B.; Apak, R. Modified cerium(IV)-based antioxidant capacity (CERAC) assay with selectivity over citric acid and simple sugars. J. Food Compos. Anal. 2010, 23, 282-288. [CrossRef] 
139. Işık, E.; Şahin, S.; Demir, C. Development of a new chromium reducing antioxidant capacity (CHROMAC) assay for plants and fruits. Talanta 2013, 111, 119-124. [CrossRef]

140. Priya, D.; Rajaram, K.; Suresh-kumar, P. In vitro antioxidant and preliminary phytochemical studies of Caralluma fimbriata wall. Int. J. Pharm. Res. 2012, 4, 44-48.

141. Kumar, C.S.; Loh, W.S.; Ooi, C.W.; Quah, C.K.; Fun, H.K. Structural correlation of some heterocyclic chalcone analogues and evaluation of their antioxidant potential. Molecules 2013, 18, 11996-12011. [CrossRef] [PubMed]

142. Kikuzaki, H.; Nakatani, N. Antioxidant Effects of Some Ginger Constituents. J. Food Sci. 1993, 58, 1407-1410. [CrossRef]

143. Sharma, B.; Purkayastha, D.D.; Hazra, S.; Thajamanbi, M.; Bhattacharjee, C.R.; Ghosh, N.N.; Rout, J. Biosynthesis of fluorescent gold nanoparticles using an edible freshwater red alga, Lemanea fluviatilis (L.) C.Ag. and antioxidant activity of biomatrix loaded nanoparticles. Bioprocess Biosyst. Eng. 2014, 37, 2559-2565. [CrossRef] [PubMed]

144. Friel, J.K.; Diehl-Jones, W.L.; Suh, M.; Tsopmo, A.; Shirwadkar, V.P. Impact of iron and vitamin C-containing supplements on preterm human milk: In vitro. Free Radic. Biol. Med. 2007, 42, 1591-1598. [CrossRef] [PubMed]

145. Özyürek, M.; Güçlü, K.; Tütem, E.; Başkan, K.S.; Erçağ, E.; Esin Çelik, S.; Baki, S.; Yildiz, L.; Karaman, S.; Apak, R. A comprehensive review of CUPRAC methodology. Anal. Methods 2011, 3, 2439-2453. [CrossRef]

146. Kunchandy, E.; Rao, M.N.A. Oxygen radical scavenging activity of curcumin. Int. J. Pharm. 1990, 58, 237-240. [CrossRef]

147. Aguilar Diaz De Leon, J.; Borges, C.R. Evaluation of Oxidative Stress in Biological Samples Using the Thiobarbituric Acid Reactive Substances Assay. J. Vis. Exp. 2020, 159. [CrossRef]

148. Moon, J.K.; Shibamoto, T. Antioxidant Assays for Plant and Food Components. J. Agric. Food Chem. 2009, 57, 1655-1666. [CrossRef] [PubMed]

149. Re, R.; Pellegrini, N.; Proteggente, A.; Pannala, A.; Yang, M.; Rice-Evans, C. Antioxidant activity applying an improved ABTS radical cation decolorization assay. Free Radic. Biol. Med. 1999, 26, 1231-1237. [CrossRef]

150. Asghar, M.N.; Khan, I.U.; Arshad, M.N.; Sherin, L. Evaluation of Antioxidant Activity Using an Improved DMPD Radical Cation Decolorization Assay. Acta Chim. Slov. 2007, 54, 295-300.

151. Damien Dorman, H.J.; Shikov, A.N.; Pozharitskaya, O.N.; Hiltunen, R. Antioxidant and pro-oxidant evaluation of a Potentilla alba L. rhizome extract. Chem. Biodivers. 2011, 8, 1344-1356. [CrossRef] [PubMed]

152. Fontana, M.; Mosca, L.; Rosei, M.A. Interaction of enkephalins with oxyradicals. Biochem. Pharmacol. 2001, 61, 1253-1257. [CrossRef]

153. Habu, J.B.; Ibeh, B.O. In vitro antioxidant capacity and free radical scavenging evaluation of active metabolite constituents of Newbouldia laevis ethanolic leaf extract. Biol. Res. 2015, 48, 16. [CrossRef] [PubMed]

154. Bailly, F.; Zoete, V.; Vamecq, J.; Catteau, J.P.; Bernier, J.L. Antioxidant actions of ovothiol-derived 4-mercaptoimidazoles: Glutathione peroxidase activity and protection against peroxynitrite-induced damage. FEBS Lett. 2000, 486, 19-22. [CrossRef]

155. Ou, B.; Hampsch-Woodill, M.; Flanagan, J.; Deemer, E.K.; Prior, R.L.; Huang, D. Novel Fluorometric Assay for Hydroxyl Radical Prevention Capacity Using Fluorescein as the Probe. J. Agric. Food Chem. 2002, 50, 2772-2777. [CrossRef] [PubMed]

156. Chu, Y.H.; Chang, C.L.; Hsu, H.F. Flavonoid content of several vegetables and their antioxidant activity. J. Sci. Food Agric. 2000, 80, 561-566. [CrossRef]

157. Cheng, Z.; Zhou, H.; Yin, J.; Yu, L. Electron spin resonance estimation of hydroxyl radical scavenging capacity for lipophilic antioxidants. J. Agric. Food Chem. 2007, 55, 3325-3333. [CrossRef] [PubMed]

158. Carini, M.; Aldini, G.; Piccone, M.; Facino, R.M. Fluorescent probes as markers of oxidative stress in keratinocyte cell lines following UVB exposure. Farmaco 2000, 55, 526-534. [CrossRef]

159. Nabavi, S.M.; Ebrahimzadeh, M.A.; Nabavi, S.F.; Hamidinia, A.; Bekhradnia, A.R. Determination of antioxidant activity, phenol and flavonoids content of Parrotia persica Mey. Pharmacologyonline 2008, 2, 560-567.

160. Pedraza-Chaverri, J.; Barrera, D.; Maldonado, P.D.; Chirino, Y.I.; Macias-Ruvalcaba, N.A.; Medina-Campos, O.N.; Castro, L.; Salcedo, M.I.; Hernandez-Pando, R. S-allylmercaptocysteine scavenges hydroxyl radical and singlet oxygen in vitro and attenuates gentamicin-induced oxidative and nitrosative stress and renal damage in vivo. BMC Clin. Pharmacol. 2004, 4, 5. [CrossRef]

161. Macku, C.; Shibamoto, T. Volatile antioxidants produced from heated corn oil/glycine model system. J. Agric. Food Chem. 1991, 39, 1990-1993. [CrossRef]

162. Sudan, R.; Bhagat, M.; Gupta, S.; Singh, J.; Koul, A. Iron (FeII) Chelation, Ferric Reducing Antioxidant Power, and Immune Modulating Potential of Arisaema jacquemontii (Himalayan Cobra Lily). BioMed. Res. Int. 2014. [CrossRef]

163. Sousa, S.J.; Brizola, V.R.A.; Granato, D. High-throughput assay comparison and standardization for metal chelating capacity screening: A proposal and application. Food Chem. 2017, 214, 515-522. [CrossRef]

164. Rodriguez-Amaya, D.B. Quantitative analysis, in vitro assessment of bioavailability and antioxidant activity of food carotenoids -A review. J. Food Compos. Anal. 2010, 23, 726-740. [CrossRef]

165. Fukai, T.; Ushio-Fukai, M. Superoxide dismutases: Role in redox signaling, vascular function, and diseases. Antioxid. Redox Signal. 2011, 15, 1583-1606. [CrossRef]

166. Brigelius-Flohé, R.; Maiorino, M. Glutathione peroxidases. Biochim. Biophys. Acta 2013, 1830, 3289-3303. [CrossRef]

167. Rhee, S.G.; Kang, S.W.; Chang, T.S.; Jeong, W.; Kim, K. Peroxiredoxin, a novel family of peroxidases. IUBMB Life 2001, 52, 35-41. [CrossRef] [PubMed] 
168. Arnér, E.S.; Holmgren, A. Physiological functions of thioredoxin and thioredoxin reductase. Eur. J. Biochem. 2000, 267, 6102-6109. [CrossRef] [PubMed]

169. Pellegrini, N.; Serafini, M.; Colombi, B.; Del Rio, D.; Salvatore, S.; Bianchi, M.; Brighenti, F. Total antioxidant capacity of plant foods, beverages and oils consumed in Italy assessed by three different in vitro assays. J. Nutr. 2003, 133, 2812-2819. [CrossRef]

170. Gómez-Alonso, S.; Mancebo-Campos, V.; Salvador, M.D.; Fregapane, G. Evolution of major and minor components and oxidation indices of virgin olive oil during 21 months storage at room temperature. Food Chem. 2007, 100, 36-42. [CrossRef]

171. Reis, F.S.; Martins, A.; Barros, L.; Ferreira, I.C. Antioxidant properties and phenolic profile of the most widely appreciated cultivated mushrooms: A comparative study between in vivo and in vitro samples. Food Chem. Toxicol. 2012, 50, 1201-1207. [CrossRef] [PubMed]

172. Marcocci, L.; Maguire, J.J.; Droy-Lefaix, M.T.; Packer, L. The nitric oxide-scavenging properties of Ginkgo biloba extract EGb 761. Biochem. Biophys. Res. Commun. 1994, 201, 748-755. [CrossRef]

173. Prior, R.L.; Wu, X.; Schaich, K. Standardized methods for the determination of antioxidant capacity and phenolics in foods and dietary supplements. J. Agric. Food Chem. 2005, 53, 4290-4302. [CrossRef]

174. Prieto, P.; Pineda, M.; Aguilar, M. Spectrophotometric quantitation of antioxidant capacity through the formation of a phosphomolybdenum complex: Specific application to the determination of vitamin E. Anal. Biochem. 1999, 269, 337-341. [CrossRef]

175. Goldschmidt, S.; Renn, K. Zweiwertiger Stickstoff: Über das $\alpha, \alpha$-Diphenyl- $\beta$-trinitrophenyl-hydrazyl. (IV. Mitteilung über Amin-Oxydation). Chem. Ber. 1922, 55, 628-643. [CrossRef]

176. Molyneux, P. The use of the stable free radical diphenylpicrylhydrazyl (DPPH) for estimating antioxidant activity. Songklanakarin. J. Sci. Technol. 2004, 26, 211-219.

177. Blois, M. Antioxidant Determinations by the Use of a Stable Free Radical. Nature 1958, 181, 1199-1200. [CrossRef]

178. Mishra, K.; Ojha, H.; Chaudhury, N.K. Estimation of antiradical properties of antioxidants using DPPH• assay: A critical review and results. Food Chem. 2012, 130, 1036-1043. [CrossRef]

179. Osman, A.M. Multiple pathways of the reaction of 2,2-diphenyl-1-picrylhydrazyl radical (DPPH•) with (+)-catechin: Evidence for the formation of a covalent adduct between (DPPH•) and the oxidized form of the polyphenol. Biochem. Biophys. Res. Commun. 2011, 412, 473-478. [CrossRef]

180. Passari, A.K.; Leo, V.V.; Singh, G.; Samanta, L.; Ram, H.; Siddaiah, C.N.; Hashem, A.; Al-Arjani, A.-B.F.; Alqarawi, A.A.; Fathi Abd_Allah, E.; et al. In Vivo Studies of Inoculated Plants and In Vitro Studies Utilizing Methanolic Extracts of Endophytic Streptomyces sp. Strain DBT34 Obtained from Mirabilis jalapa L. Exhibit ROS-Scavenging and Other Bioactive Properties. Int. J. Mol. Sci. 2020, 21, 7364. [CrossRef]

181. Ražná, K.; Sawinska, Z.; Ivanišová, E.; Vukovic, N.; Terentjeva, M.; Stričík, M.; Kowalczewski, P.Ł.; Hlavačková, L.; Rovná, K.; Žiarovská, J.; et al. Properties of Ginkgo biloba L.: Antioxidant Characterization, Antimicrobial Activities, and Genomic MicroRNA Based Marker Fingerprints. Int. J. Mol. Sci. 2020, 21, 3087. [CrossRef]

182. Gois Ruivo da Silva, M.; Skrt, M.; Komes, D.; Poklar Ulrih, N.; Pogačnik, L. Enhanced Yield of Bioactivities from Onion (Allium cepa L.) Skin and Their Antioxidant and Anti- $\alpha$-Amylase Activities. Int. J. Mol. Sci. 2020, 21, 2909. [CrossRef]

183. Pisoschi, A.M.; Cheregi, M.C.; Danet, A.F. Total Antioxidant Capacity of Some Commercial Fruit Juices: Electrochemical and Spectrophotometrical Approaches. Molecules 2009, 14, 480-493. [CrossRef]

184. McGowan, J.C.; Powell, T.; Raw, R. The rates of reaction of $\alpha, \alpha$-diphenyl- $\beta$-picrylhydrazyl with certain amines and phenols. J. Chem. Soc. 1959, 1959, 3103-3110. [CrossRef]

185. Hogg, J.S.; Lohmann, D.H.; Russell, K.S. The kinetics of reaction of 2,2-diphenyl-1-picrylhydrazyl with phenols. Can. J. Chem. 1961, 39, 1588-1594. [CrossRef]

186. Apak, R.; Gorinstein, S.; Böhm, V.; Schaich, K.M.; Özyürek, M.; Güçlü, K. Methods of measurement and evaluation of natural antioxidant capacity/activity. Pure Appl. Chem. 2013, 85, 957-998. [CrossRef]

187. Brand-Williams, W.; Cuvelier, M.E.; Berset, C. Use of a free radical method to evaluate antioxidant activity. LWT-Food Sci. Technol. 1995, 28, 25-30. [CrossRef]

188. Cheng, Z.; Moore, J.; Yu, L. High-throughput relative DPPH radical scavenging capacity assay. J. Agric Food Chem. 2006, 54, 7429-7436. [CrossRef]

189. Bondet, V.; Brand-Williams, W.; Berset, C. Kinetics and mechanisms of antioxidant activity using the DPPH radical method. LWT-Food Sci. Technol. 1997, 30, 609-615. [CrossRef]

190. Xie, J.; Schaich, K.M. Re-evaluation of the 2,2-Diphenyl-1-picrylhydrazyl Free Radical (DPPH) Assay for Antioxidant Activity. J. Agric. Food Chem. 2014, 62, 4251-4260. [CrossRef]

191. Alexander, B.; Browse, D.J.; Reading, S.J.; Benjamin, I.S. A simple and accurate mathematical method for calculation of the EC50. J. Pharmacol. Toxicol. Methods 1999, 41, 55-58. [CrossRef]

192. Chen, Z.; Bertin, R.; Froldi, G. EC50 estimation of antioxidant activity in DPPH·assay using several statistical programs. Food Chem. 2013, 138, 414-420. [CrossRef] [PubMed]

193. Van der Graaf, P.H.; Schoemaker, R.C. Analysis of asymmetry of agonist concentration-effect curves. J. Pharmacol. Toxicol. Methods 1999, 41, 107-115. [CrossRef]

194. Ukeda, H.; Adachi, Y.; Sawamura, M. Flow injection analysis of DPPH radical based on electron spin resonance. Talanta 2002, 58, 1279-1283. [CrossRef]

195. Ukeda, H. Flow-injection analytical system for the evaluation of antioxidative activity. Bunseki Kagaku 2004, 53, 221. [CrossRef] 
196. Polásek, M.; Skála, P.; Opletal, L.; Jahodár, L. Rapid automated assay of anti-oxidation/radical-scavenging activity of natural substances by sequential injection technique (SIA) using spectrophotometric detection. Anal. Bioanal. Chem. 2004, 379, 754-758. [CrossRef]

197. Yamaguchi, T.; Takamura, H.; Matoba, T.; Terao, J. HPLC method for evaluation of the free radical-scavenging activity of foods by using 1,1-diphenyl-2-picrylhydrazyl. Biosci. Biotechnol. Biochem. 1998, 62, 1201-1204. [CrossRef]

198. Koleva, I.I.; Niederländer, H.A.; van Been, T.A. An on-line HPLC method for detection of radical scavenging compounds in complex mixtures. Anal. Chem. 2000, 72, 2323-2328. [CrossRef]

199. Cerdà, V.; Estela, J.M.; Forteza, R.; Cladera, A.; Becerra, E.; Altimira, P.; Sitjar, P. Flow techniques in water analysis. Talanta 1999, 50, 695-705. [CrossRef]

200. Wu, C.; Chen, F.; Wang, X.; Wu, Y.; Dong, M.; He, G.; Galyean, R.D.; He, L.; Huang, G. Tanacetum parthenium by HPLC-ESIMS/MS and NMR. Phytochem. Anal. 2007, 18, 401-410. [CrossRef]

201. Nuengchamnong, N.; de Jong, C.F.; Bruyneel, B.; Niessen, W.M.; Irth, H.; Ingkaninan, K. HPLC coupled on-line to ESI-MS and a DPPH-based assay for the rapid identification of anti-oxidants in Butea superba. Phytochem. Anal. 2005, 16, 422-428. [CrossRef]

202. Tang, D.; Li, H.J.; Chen, J.; Guo, C.W.; Li, P. Rapid and simple method for screening of natural antioxidants from Chinese herb Flos Lonicerae Japonicae by DPPH-HPLC-DAD-TOF/MS. J. Sep. Sci. 2008, 31, 3519-3526. [CrossRef]

203. Glavind, J.; Holmer, G. Thin-Layer Chromatographic Determination of Antioxidants by the Stable Free Radical Diphenylpicrylhydrazyl. J. Am. Oil Chem. Soc. 1967, 44, 539-542. [CrossRef]

204. Li, P.; Anu, H.; Jari, S.; Teijo, Y.; Heikki, V. TLC Method for Evaluation of Free Radical Scavenging Activity of Rapeseed Meal by Video Scanning Technology. In Proceedings of the 10th International Rapseed Congress, Canberra, Australia, 26-29 September 1999; Available online: http://www.regional.org.au/au/gcirc/1/551.htm (accessed on 30 September 2008).

205. Blasco, A.J.; Rogerio, M.C.; Gonzalez, M.C.; Escarpa, A. "Electrochemical Index" as a screening method to determine "total polyphenolics" in foods: A proposal. Anal. Chim. Acta 2005, 539, 237-244. [CrossRef]

206. Chevion, S.; Roberts, M.A.; Chevion, M. The use of cyclic voltammetry for the evaluation of antioxidant capacity. Free Radic. Biol. Med. 2000, 28, 860-870. [CrossRef]

207. Martinez, S.; Valek, L.; Resetic, J.; Rusic, D.F. Cyclic voltammetry study of plasma antioxidant capacity-comparison with the DPPH and TAS spectrophotometric methods. J. Electroanal. Chem. 2006, 588, 68-73. [CrossRef]

208. Zielińska, D.; Zieliński, H. Antioxidant activity of flavone C-glucosides determined by updated analytical strategies. Food Chem. 2011, 124, 672-678. [CrossRef]

209. Zielińska, D.; Turemko, M. Electroactive Phenolic Contributors and Antioxidant Capacity of Flesh and Peel of 11 Apple Cultivars Measured by Cyclic Voltammetry and HPLC-DAD-MS/MS. Antioxidants 2020, 9, 1054. [CrossRef] [PubMed]

210. Milardovic, S.; Ivekovic, D.; Rumenjak, V.; Bozidar, S.G. Use of DPPH./DPPH redox couple for biamperometric determination of antioxidant activity. Electroanalysis 2005, 17, 1847-1853. [CrossRef]

211. Baig, N.; Kammakakam, I.; Falath, W. Nanomaterials: A review of synthesis methods, properties, recent progress, and challenges. Mater. Adv. 2021, 2, 1821-1871. [CrossRef]

212. Katz, E.; Willner, I. Integrated nanoparticle-biomolecule hybrid systems: Synthesis, properties, and applications. Angew. Chem. Int. Ed. Engl. 2004, 43, 6042-6108. [CrossRef] [PubMed]

213. Katz, E.; Willner, I.; Wang, J. Electroanalytical and Bioelectroanalytical Systems Based on Metal and Semiconductor Nanoparticles. Electroanalysis 2004, 16, 19-44. [CrossRef]

214. Rosi, N.L.; Mirkin, C.A. Nanostructures in biodiagnostics. Chem. Rev. 2005, 105, 1547-1562. [CrossRef]

215. Vasilescu, A.; Sharpe, E.; Andreescu, S. Nanoparticle-Based Technologies for the Detection of Food Antioxidants. Curr. Anal. Chem. 2012, 8, 495-505. [CrossRef]

216. Mourdikoudis, S.; Pallares, R.M.; Thanh, N.T.K. Characterization techniques for nanoparticles: Comparison and complementarity upon studying nanoparticle properties. Nanoscale 2018, 10, 12871-12934. [CrossRef]

217. Hendrickson, O.D.; Safenkova, I.V.; Zherdev, A.V.; Dzantiev, B.B.; Popov, V.O. Methods of detection and identification of manufactured nanoparticles. Biophysics 2011, 56, 961-986. [CrossRef]

218. Szydlowska-Czerniak, A.; Tulodziecka, A. Comparison of a silver nanoparticle-based method and the modified spectrophotometric methods for assessing antioxidant capacity of rapeseed varieties. Food Chem. 2013, 141, 1865-1871. [CrossRef] [PubMed]

219. Rao, Y.; Chen, Q.; Dong, J.; Qian, W. Growth-sensitive 3D ordered gold nanoshells precursor composite arrays as SERS nanoprobes for assessing hydrogen peroxide scavenging activity. Analyst 2011, 136, 769-774. [CrossRef] [PubMed]

220. Zhao, W.; Brook, M.A.; Li, Y.F. Design of Gold NanoparticleBased Colorimetric Biosensing Assays. ChemBioChem 2008, 9 , 2363-2371. [CrossRef]

221. Ma, X.; Qian, W. Phenolic acid induced growth of gold nanoshells precursor composites and their application in antioxidant capacity assay. Biosens. Bioelectron. 2010, 26, 1049-1055. [CrossRef]

222. Alzahrani, E. Colorimetric Detection Based on Localised Surface Plasmon Resonance Optical Characteristics for the Detection of Hydrogen Peroxide Using Acacia Gum-Stabilised Silver Nanoparticles. Anal. Chem. Insights 2017. [CrossRef] [PubMed]

223. Gatselou, V.; Christodouleas, D.C.; Kouloumpis, A.; Gournis, D.; Giokas, D.L. Determination of phenolic compounds using spectral and color transitions of rhodium nanoparticles. Anal. Chim. Acta 2016, 932, 80-87. [CrossRef]

224. Dahle, T.; Arai, Y. Environmental geochemistry of cerium: Applications and toxicology of cerium oxide nanoparticles. Int. J. Environ. Res. Public Health 2015, 12, 1253-1278. [CrossRef] 
225. Ozdemir Olgun, F.A.; Üzer, A.; Ozturk, B.D.; Apak, R. A novel cerium oxide nanoparticles-based colorimetric sensor using tetramethyl benzidine reagent for antioxidant activity assay. Talanta 2018, 182, 55-61. [CrossRef]

226. Sharpe, E.; Frasco, T.; Andreescu, D.; Andreescu, S. Portable ceria nanoparticle-based assay for rapid detection of food antioxidants (NanoCerac). Analyst 2013, 138, 249-262. [CrossRef]

227. Sharpe, E.; Bradley, R.; Frasco, T.; Jayathilaka, D.; Marsh, A.; Andreescu, S. Metal oxide-based multisensor array and portable database for field analysis of antioxidants. Sens. Actuators B-Chem. 2014, 193, 552-562. [CrossRef]

228. Lopez-Alarcon, C.; Denicola, A. Evaluating the antioxidant capacity of natural products: A review on chemical and cellular-based assays. Anal. Chim. Acta 2013, 763, 1-10. [CrossRef]

229. Alarcon-Angeles, G.; Alvarez-Romero, G.A.; Merkoci, A. Emerging Nanomaterials for Analytical Detection. Biosensors for Sustainable Food-New Opportunities and Technical Challenges. Compr. Anal. Chem. 2016, 74, 195-246. [CrossRef]

230. Della Pelle, F.; Compagnone, D. Nanomaterial-Based Sensing and Biosensing of Phenolic Compounds and Related Antioxidant Capacity in Food. Sensors 2018, 18, 462. [CrossRef]

231. Bedlovičová, Z.; Strapáč, I.; Baláž, M.; Salayová, A. A Brief Overview on Antioxidant Activity Determination of Silver Nanoparticles. Molecules 2020, 25, 3191. [CrossRef]

232. Vilela, D.; Gonzalez, M.C.; Escarpa, A. Nanoparticles as analytical tools for in-vitro antioxidant-capacity assessment and beyond. $\operatorname{Tr} A C$ 2015, 64, 1-16. [CrossRef]

233. Ganesan, K.; Kumar, K.S.; Rao, P.V.S. Comparative assessment of antioxidant activity in three edible species of green seaweed, Enteromorpha from Okha, northwest coast of India. Innov. Food Sci. Emerg. Technol. 2011, 12, 73-78. [CrossRef]

234. Pisoschi, A.M.; Pop, A.; Cimpeanu, C.; Predoi, G. Antioxidant Capacity Determination in Plants and Plant-Derived Products: A Review. Oxid. Med. Cell Longev. 2016, 2016, 9130976. [CrossRef]

235. Smith, R.M. Before the injection-modern methods of sample preparation for separation techniques. J. Chromatogr. A 2003, 1000, 3-27. [CrossRef]

236. Gupta, A.; Naraniwal, M.; Kothari, V. Modern extraction methods for preparation of bioactive plant extracts. Int. J. Appl. Nat. Sci. $2012,1,8-26$.

237. Lisitsyn, A.B.; Semenova, A.A.; Gundyreva, M.I. A study of the antioxidant properties of supercritical $\mathrm{CO}_{2}$ extracts. Meat Ind. 2006, 3, 30-35.

238. Luque de Castro, M.D.; García-Ayuso, L.E. Soxhlet extraction of solid materials: An outdated technique with a promising innovative future. Anal. Chim. Acta 1998, 369, 1-10. [CrossRef]

239. Buitrago, D.; Buitrago-Villanueva, I.; Barbosa-Cornelio, R.; Coy-Barrera, E. Comparative Examination of Antioxidant Capacity and Fingerprinting of Unfractionated Extracts from Different Plant Parts of Quinoa (Chenopodium quinoa) Grown under Greenhouse Conditions. Antioxidants 2019, 8, 238. [CrossRef]

240. Singh, B.P.; Rateb, M.E.; Rodriguez-Couto, S.; Polizeli, M.L.T.M.; Li, W.J. Editorial: Microbial secondary metabolites: Recent developments and technological challenges. Front. Microbiol. 2019, 10, 914. [CrossRef] [PubMed]

241. Demain, A.L. Importance of microbial natural products and the need to revitalize their discovery. J. Ind. Microbiol. Biotechnol. 2014, 41, 185-201. [CrossRef] [PubMed]

242. Min, W.H.; Fang, X.B.; Wu, T.; Fang, L.; Liu, C.L.; Wang, J. Characterization and antioxidant activity of an acidic exopolysaccharide from Lactobacillus plantarum JLAU103. J. Biosci. Bioeng. 2019, 127, 758-766. [CrossRef]

243. Yang, Z.; Li, S.; Zhang, X.; Zeng, X.; Li, D.; Zhao, Y.; Zhang, J. Capsular and slime-polysaccharide production by Lactobacillus rhamnosus JAAS8 isolated from Chinese sauerkraut: Potential application in fermented milk products. J. Biosci. Bioeng. 2010, 110, 53-57. [CrossRef] [PubMed]

244. Dose, J.; Matsugo, S.; Yokokawa, H.; Koshida, Y.; Okazaki, S.; Seidel, U.; Eggersdorfer, M.; Rimbach, G.; Esatbeyoglu, T. Free radical scavenging and cellular antioxidant properties of astaxanthin. Int. J. Mol. Sci. 2016, 17, 103. [CrossRef]

245. Naguib, Y.M.A. Antioxidant activities of astaxanthin and related carotenoids. J. Agric. Food Chem. 2000, 48, 1150-1154. [CrossRef]

246. Blagojević, D.; Babić, O.; Rašeta, M.; Šibul, F.; Janjušević, L.; Simeunović, J. Antioxidant activity and phenolic profile in filamentous cyanobacteria: The impact of nitrogen. J. Appl. Phycol. 2018, 30, 2337-2346. [CrossRef]

247. Kumar, H.; Bhardwaj, K.; Nepovimova, E.; Kuča, K.; Singh Dhanjal, D.; Bhardwaj, S.; Bhatia, S.K.; Verma, R.; Kumar, D. Antioxidant Functionalized Nanoparticles: A Combat against Oxidative Stress. Nanomaterials 2020, 10, 1334. [CrossRef]

248. Sansone, C.; Brunet, C. Promises and Challenges of Microalgal Antioxidant Production. Antioxidants 2019, 8, 199. [CrossRef]

249. Pagels, F.; Guedes, A.C.; Amaro, H.M.; Kijjoa, A.; Vasconcelos, V. Phycobiliproteins from cyanobacteria: Chemistry and biotechnological applications. Biotechnol. Adv. 2019, 37, 422-443. [CrossRef]

250. Wekre, M.E.; Kåsin, K.; Underhaug, J.; Holmelid, B.; Jordheim, M. Quantification of Polyphenols in Seaweeds: A Case Study of Ulva intestinalis. Antioxidants 2019, 8, 612. [CrossRef] [PubMed]

251. Maroneze, M.M.; Zepka, L.Q.; Lopes, E.J.; Pérez-Gálvez, A.; Roca, M. Chlorophyll Oxidative Metabolism During the Phototrophic and Heterotrophic Growth of Scenedesmus obliquus. Antioxidants 2019, 8, 600. [CrossRef]

252. Rajauria, G. In-Vitro Antioxidant Properties of Lipophilic Antioxidant Compounds from 3 Brown Seaweed. Antioxidants 2019, 8, 596. [CrossRef] [PubMed]

253. Nègre, D.; Aite, M.; Belcour, A.; Frioux, C.; Brillet-Guéguen, L.; Liu, X.; Bordron, P.; Godfroy, O.; Lipinska, A.P.; Leblanc, C.; et al. Genome-Scale Metabolic Networks Shed Light on the Carotenoid Biosynthesis Pathway in the Brown Algae Saccharina japonica and Cladosiphon okamuranus. Antioxidants 2019, 8, 564. [CrossRef] [PubMed] 
254. Neumann, U.; Derwenskus, F.; Flaiz Flister, V.; Schmid-Staiger, U.; Hirth, T.; Bischoff, S.C.; Fucoxanthin, A. Carotenoid Derived from Phaeodactylum tricornutum Exerts Antiproliferative and Antioxidant Activities In Vitro. Antioxidants 2019, 8, 183. [CrossRef]

255. Smerilli, A.; Balzano, S.; Maselli, M.; Blasio, M.; Orefice, I.; Galasso, C.; Sansone, C.; Brunet, C. Antioxidant and Photoprotection Networking in the Coastal Diatom Skeletonema marinoi. Antioxidants 2019, 8, 154. [CrossRef]

256. Xu, Y.; Harvey, P.J. Red Light Control of $\beta$-Carotene Isomerisation to 9-cis $\beta$-Carotene and Carotenoid Accumulation in Dunaliella salina. Antioxidants 2019, 8, 148. [CrossRef]

257. Le, B.; Golokhvast, K.S.; Yang, S.H.; Sun, S. Optimization of Microwave-Assisted Extraction of Polysaccharides from Ulva pertusa and Evaluation of Their Antioxidant Activity. Antioxidants 2019, 8, 129. [CrossRef] [PubMed]

258. Xu, Y.; Harvey, P.J. Carotenoid Production by Dunaliella salina under Red Light. Antioxidants 2019, 8, 123. [CrossRef]

259. Merino, J.J.; Parmigiani-Izquierdo, J.M.; Toledano Gasca, A.; Cabaña-Muñoz, M.E. The Long-Term Algae Extract (Chlorella and Fucus sp.) and Aminosulphurate Supplementation Modulate SOD-1 Activity and Decrease Heavy Metals ( $\left.\mathrm{Hg}^{++}, \mathrm{Sn}\right) \mathrm{Levels}$ in Patients with Long-Term Dental Titanium Implants and Amalgam Fillings Restorations. Antioxidants 2019, 8, 101. [CrossRef] [PubMed]

260. Ranković, B.; Kosanić, M. Lichens as a potential source of bioactive secondary metabolites. In Lichen Secondary Metabolites: Bioactive Properties and Pharmaceutical Potential; Ranković, B., Ed.; Springer International Publishing: Berlin/Heidelberg, Germany, 2015. [CrossRef]

261. Gülçin, İ.; Oktay, M.; Küfrevioğlu, Ö.İ.; Aslan, A. Determination of antioxidant activity of lichen Cetraria islandica (L.) Ach. J. Ethnopharmacol. 2002, 79, 325-329. [CrossRef]

262. Behera, B.C.; Verma, N.; Sonone, A.; Makhija, U. Antioxidant and antibacterial activities of lichen Usnea ghattensis in vitro. Biotechnol. Lett. 2005, 27, 991-995. [CrossRef]

263. Gulluce, M.; Aslan, A.; Sokmen, M.; Sahin, F.; Adiguzel, A.; Agar, G.; Sokmen, A. Screening the antioxidant and antimicrobial properties of the lichens Parmelia saxatilis, Platismatia glauca, Ramalina pollinaria, Ramalina polymorpha and Umbilicaria nylanderiana. Phytomedicine 2006, 13, 515-521. [CrossRef] [PubMed]

264. Fernández-Moriano, C.; Gómez-Serranillos, M.P.; Crespo, A. Antioxidant potential of lichen species and their secondary metabolites. A systematic review. Pharm. Biol. 2016, 54, 1-17. [CrossRef] [PubMed]

265. Kosanić, M.; Ranković, B. Lichens as possible sources of antioxidants. Pak. J. Pharm. Sci. 2011, 24, 165-170.

266. Ranković, B.; Ranković, D.; Kosanić, M.; Marić, D. Antioxidant and antimicrobial properties of the lichens Anaptychya ciliaris, Nephroma parile, Ochrolechia tartarea and Parmelia centrifuga. Cent. Eur. J. Biol. 2010, 5, 649-655. [CrossRef]

267. Bhattarai, H.D.; Paudel, B.; Hong, S.G.; Lee, H.K.; Yim, J.H. Thin layer chromatography analysis of antioxidant constituents of lichens from Antarctica. J. Nat. Med. 2008, 62, 481-484. [CrossRef] [PubMed]

268. Rajan, V.P.; Gunasekaran, S.; Ramanathan, S.; Murugaiyah, V.; Samsudin, M.W.; Din, L.B. Biological activities of four Parmotrema species of Malaysian origin and their chemical constituents. J. Appl. Pharm. Sci. 2016, 6, 36-43. [CrossRef]

269. Tomović, J.; Kosanić, M.; Ristić, S.; Ranković, B.; Stanojković, T.; Manojlović, N. Chemical composition and bioactive properties of the lichen, Pleurosticta acetabulum. Trop. J. Pharm. Res. 2017, 16, 2977-2984. [CrossRef]

270. Sisodia, R.; Geol, M.; Verma, S.; Rani, A.; Dureja, P. Antibacterial and antioxidant activity of lichen species Ramalina roesleri. Nat. Prod. Res. 2013, 27, 2235-2239. [CrossRef]

271. Kawahara, T.; Izumikawa, M.; Otoguro, M.; Yamamura, H.; Hayakawa, M.; Takagi, M.; Shin Ya, K. JBIR-94 and JBIR-125, antioxidative phenolic compounds from Streptomyces sp. R56-07. J. Nat. Prod. 2012, 75, 107-110. [CrossRef] [PubMed]

272. Lertcanawanichakul, M.; Pondet, K.; Kwantep, J. In vitro antimicrobial and antioxidant activities of bioactive compounds (secondary metabolites) extracted from Streptomyces lydicus A2. J. Appl. Pharm. Sci. 2015, 5, 17-21. [CrossRef]

273. Kiruthika, P.; Durairaju Nisshanthini, S.; Angayarkanni, J. In vitro antimicrobial and antioxidant profile of Streptomyces spp. isolated from coromandel coast region, India. Int. J. Pharma Bio Sci. 2013, 4, 127-136.

274. Lee, D.R.; Lee, S.K.; Choi, B.K.; Cheng, J.; Lee, Y.S.; Yang, S.H.; Suh, J.W. Antioxidant activity and free radical scavenging activities of Streptomyces sp. strain MJM 10778. Asian Pac. J. Trop. Med. 2014, 7, 962-967. [CrossRef]

275. Janardhan, A.; Kumar, A.P.; Viswanath, B.; Saigopal, D.V.R.; Narasimha, G. Production of Bioactive Compounds by Actinomycetes and Their Antioxidant Properties. Biotechnol. Res. Int. 2014, 1-8. [CrossRef] [PubMed]

276. Thenmozhi, M.; Sindhura, S.; Kannabiran, K. Characterization of antioxidant activity of Streptomyces species VITTK3 isolated from Puducherry coast, India. J. Adv. Sci. Res. 2010, 1, 46-52.

277. Saurav, K.; Kannabiran, K. Cytotoxicity and antioxidant activity of 5-(2,4-dimethylbenzyl)pyrrolidin-2-one extracted from marine Streptomyces VITSVK5 spp. Saudi J. Biol. Sci. 2012, 19, 81-86. [CrossRef] [PubMed]

278. Komiyama, K.; Funayama, S.; Anraku, Y.; Mita, A.; Takahashi, Y.; Omura, S.; Shimasaki, H. Isolation of isoflavonoids possessing antioxidant activity from the fermentation broth of Streptomyces spp. J. Antibiot. 1989, 42, 1344-1349. [CrossRef]

279. Ielciu, I.; Frédérich, M.; Hanganu, D.; Angenot, L.; Olah, N.-K.; Ledoux, A.; Crișan, G.; Păltinean, R. Flavonoid Analysis and Antioxidant Activities of the Bryonia alba L. Aerial Parts. Antioxidants 2019, 8, 108. [CrossRef] [PubMed]

280. Chaves, N.; Santiago, A.; Alías, J.C. Quantification of the Antioxidant Activity of Plant Extracts: Analysis of Sensitivity and Hierarchization Based on the Method Used. Antioxidants 2020, 9, 76. [CrossRef]

281. Gougoulias, N. Evaluation of antioxidant activity and polyphenol content of leaves from some fruit species. Oxid. Commun. 2015, $38,35-45$. 
282. Katalinic, V.; Mozina, S.S.; Generalic, I.; Skroza, D.; Ljubenkov, I.; Klancnik, A. Phenolic Profile, Antioxidant Capacity, and Antimicrobial Activity of Leaf Extracts from Six Vitis vinifera, L. Varieties. Int. J. Food Prop. 2013, 16, 45-60. [CrossRef]

283. Medlej, M.K.; Batoul, C.; Olleik, H.; Li, S.; Hijazi, A.; Nasser, G.; Maresca, M.; Pochat-Bohatier, C. Antioxidant Activity and Biocompatibility of Fructo-Polysaccharides Extracted from a Wild Species of Ornithogalum from Lebanon. Antioxidants 2021, 10, 68. [CrossRef]

284. Attanzio, A.; D'Anneo, A.; Pappalardo, F.; Bonina, F.P.; Livrea, M.A.; Allegra, M.; Tesoriere, L. Phenolic Composition of Hydrophilic Extract of Manna from Sicilian Fraxinus angustifolia Vahl and its Reducing, Antioxidant and Anti-Inflammatory Activity in Vitro. Antioxidants 2019, 8, 494. [CrossRef]

285. Skenderidis, P.; Lampakis, D.; Giavasis, I.; Leontopoulos, S.; Petrotos, K.; Hadjichristodoulou, C.; Tsakalof, A. Chemical Properties, Fatty-Acid Composition, and Antioxidant Activity of Goji Berry (Lycium barbarum L. and Lycium chinense Mill.) Fruits. Antioxidants 2019, 8, 60. [CrossRef]

286. Flieger, J.; Flieger, M. The [DPPH•/DPPH-H]-HPLC-DAD Method on Tracking the Antioxidant Activity of Pure Antioxidants and Goutweed (Aegopodium podagraria L.) Hydroalcoholic Extracts. Molecules 2020, 25, 6005. [CrossRef] [PubMed]

287. Uma Anitha, K.P.G.; Mythili, S. Antioxidant and hepatoprotective potentials of novel endophytic fungus Achaetomium sp., from Euphorbia hirta. Asian Pac. J. Trop. Med. 2017, 10, 588-593. [CrossRef] [PubMed]

288. Sugiharto, S.; Yudiarti, T.; Isroli, I. Assay of Antioxidant Potential of Two Filamentous Fungi Isolated from the Indonesian Fermented Dried Cassava. Antioxidants 2016, 5, 6. [CrossRef] [PubMed]

289. Arora, D.S.; Chandra, P. In vitro antioxidant potential of some soil fungi: Screening of functional compounds and their purification from Penicillium citrinum. Appl. Biochem. Biotechnol. 2011, 165, 639-651. [CrossRef] [PubMed]

290. Yadav, M.; Yadav, A.; Yadav, J.P. In vitro antioxidant activity and total phenolic content of endophytic fungi isolated from Eugenia jambolana Lam. Asian Pac. J. Trop. Med. 2014, 7S1, S256-S261. [CrossRef]

291. Li, T.X.; Meng, D.D.; Wang, Y.; An, J.L.; Bai, J.F.; Jia, X.W.; Xu, C.P. Antioxidant coumarin and pyrone derivatives from the insect-associated fungus Aspergillus versicolor. Nat. Prod. Res. 2020, 34, 1360-1365. [CrossRef]

292. Zhang, H.; Wang, Z.Y.; Yang, L.; Yang, X.; Wang, X.; Zhang, Z. In vitro antioxidant activities of sulfated derivatives of polysaccharides extracted from Auricularia auricular. Int. J. Mol. Sci. 2011, 12, 3288-3302. [CrossRef]

293. Huang, X.Z.; Zhu, Y.; Guan, X.L.; Tian, K.; Guo, J.M.; Wang, H.B.; Fu, G.M. A novel antioxidant isobenzofuranone derivative from fungus Cephalosporium sp.AL031. Molecules 2012, 17, 4219-4224. [CrossRef]

294. Jaszek, M.; Osińska-Jaroszuk, M.; Janusz, G.; Matuszewska, A.; Stefaniuk, D.; Sulej, J.; Polak, J.; Ruminowicz, M.; Grzywnowicz, K.; Jarosz-Wilkołazka, A. New bioactive fungal molecules with high antioxidant and antimicrobial capacity isolated from Cerrena unicolor idiophasic cultures. Biomed. Res. Int. 2013, 2013, 1-11. [CrossRef]

295. Shah, S.R.; Ukaegbu, C.I.; Hamid, H.A.; Alara, O.R. Evaluation of antioxidant and antibacterial activities of the stems of Flammulina velutipes and Hypsizygus tessellates (white and brown var.) extracted with different solvents. J. Food Meas. Charact. 2018, 12, 1947-1961. [CrossRef]

296. Abdullah, N.; Ismail, S.M.; Aminudin, N.; Shuib, A.S.; Lau, B.F. Evaluation of Selected Culinary-Medicinal Mushrooms for Antioxidant and ACE Inhibitory Activities. Evid. Based Complement. Alternat. Med. 2012, 2012, 464238. [CrossRef]

297. Chandra, P.; Arora, D.S. Antioxidant Potential of Penicillium expansum and Purification of its Functional Compound. Asian J. Biotechnol. 2017, 9, 24-34. [CrossRef]

298. Arora, D.S.; Sharma, R.K.; Chandra, P. Biodelignification of wheat straw and its effect on in vitro digestibility and antioxidant properties. Int. Biodeterior. Biodegrad. 2011, 65, 352-358. [CrossRef]

299. Babu, D.R.; Pandey, M.; Rao, G.N. Antioxidant and electrochemical properties of cultivated Pleurotus spp. and their sporeless/low sporing mutants. J. Food Sci. Technol. 2012, 51, 3317-3324. [CrossRef] [PubMed]

300. Knežević, A.; Stajić, M.; Sofrenić, I.; Stanojković, T.; Milovanović, I.; Tešević, V.; Vukojević, J. Antioxidative, antifungal, cytotoxic and antineurodegenerative activity of selected Trametes species from Serbia. PLoS ONE 2018, 13, e0203064. [CrossRef] [PubMed]

301. Kodali, V.P.; Sen, R. Antioxidant and free radical scavenging activities of an exopolysaccharide from a probiotic bacterium. Biotechnol. J. 2008, 3, 245-251. [CrossRef]

302. Adesulu-Dahunsi, A.; Sanni, A.; Jeyaram, K. Production, characterization and in vitro antioxidant activities of exopolysaccharide from Weissella cibaria GA44. LWT Food Sci. Technol. 2018, 87, 432-442. [CrossRef]

303. Zhang, L.; Liu, C.; Li, D.; Zhao, Y.; Zhang, X.; Zeng, X.; Yang, Z.; Li, S. Antioxidant activity of an exopolysaccharide isolated from Lactobacillus plantarum C88. Int. J. Biol. Macromol. 2013, 54, 270-275. [CrossRef] [PubMed]

304. Akinsanya, M.A.; Goh, J.K.; Lim, S.P.; Ting, A.S. Diversity, antimicrobial and antioxidant activities of culturable bacterial endophyte communities in Aloe vera. FEMS Microbiol. Lett. 2015, 362, fnv184. [CrossRef]

305. Horta, A.; Pinteus, S.; Alves, C.; Fino, N.; Silva, J.; Fernandez, S.; Rodrigues, A.; Pedrosa, R. Antioxidant and antimicrobial potential of the Bifurcaria bifurcata epiphytic bacteria. Mar. Drugs 2014, 12, 1676-1689. [CrossRef]

306. Kato, S.; Shindo, K.; Yamagishi, Y.; Matsuoka, M.; Kawai, H.; Mochizuki, J. Phenazoviridin, a novel free radical scavenger from Streptomyces sp. Taxonomy, fermentation, isolation, structure elucidation and biological properties. J. Antibiot. 1993, 46, 1485-1493. [CrossRef]

307. Aguilar-Toalá, J.E.; Astiazarán-García, H.; Estrada-Montoya, M.C.; Garcia, H.S.; Vallejo-Cordoba, B.; González-Córdova, A.F.; Hernández-Mendoza, A. Modulatory Effect of the Intracellular Content of Lactobacillus casei CRL 431 Against the Aflatoxin $\mathrm{B}_{1}$-Induced Oxidative Stress in Rats. Probiotics Antimicrob. Proteins. 2019, 11, 470-477. [CrossRef] 
308. Wang, K.; Niu, M.; Yao, D.; Zhao, J.; Wu, Y.; Lu, B.; Zheng, X. Physicochemical characteristics and in vitro and in vivo antioxidant activity of a cell-bound exopolysaccharide produced by Lactobacillus fermentum S1. Int. J. Biol. Macromol. 2019, 139, $252-261$. [CrossRef]

309. Liu, C.F.; Tseng, K.C.; Chiang, S.S.; Lee, B.H.; Hsu, W.H.; Pan, T.M. Immunomodulatory and antioxidant potential of Lactobacillus exopolysaccharides. J. Sci. Food Agric. 2011, 91, 2284-2291. [CrossRef] [PubMed]

310. González-Ballesteros, N.; Rodríguez-Argüelles, M.C.; Lastra-Valdor, M. Evaluation of the Antioxidant Capacities of Antarctic Macroalgae and Their Use for Nanoparticles Production. Molecules 2021, 26, 1182. [CrossRef]

311. Régnier, P.; Bastias, J.; Rodriguez-Ruiz, V.; Caballero-Casero, N.; Caballo, C.; Sicilia, D.; Fuentes, A.; Maire, M.; Crepin, M.; Letourneur, D.; et al. Astaxanthin from Haematococcus pluvialis Prevents Oxidative Stress on Human Endothelial Cells without Toxicity. Mar. Drugs 2015, 13, 2857-2874. [CrossRef] [PubMed]

312. Sueishi, Y.; Ishikawa, M.; Yoshioka, D.; Endoh, N.; Oowada, S.; Shimmei, M.; Fujii, H.; Kotake, Y. Oxygen radical absorbance capacity (ORAC) of cyclodextrin-solubilized flavonoids, resveratrol and astaxanthin as measured with the ORAC-EPR method. $J$. Clin. Biochem. Nutr. 2012, 50, 127-132. [CrossRef]

313. Widowati, I.; Zainuri, M.; Kusumaningrum, H.P.; Susilowati, R.; Hardivillier, Y.; Leignel, V.; Bourgougnon, N.; Mouget, J.L. Antioxidant activity of three microalgae Dunaliella salina, Tetraselmis chuii and Isochrysis galbana clone Tahiti. IOP Conf. Ser. Earth Environ. Sci. 2017, 55, 012067. [CrossRef]

314. Gürlek, C.; Yarkent, C.; Köse, A.; Oral, I.; Öncel, S.S.; Elibol, M. Evaluation of several microalgal extracts as bioactive metabolites as potential pharmaceutical compounds. In Proceedings of the CMBEBIH 2019: Proceedings of the International Conference on Medical and Biological Engineering, Banja Luka, Bosnia and Herzegovina, 16-18 May 2019.

315. Agregán, R.; Munekata, P.E.S.; Franco, D.; Carballo, J.; Barba, F.J.; Lorenzo, J.M. Antioxidant Potential of Extracts Obtained from Macro- (Ascophyllum nodosum, Fucus vesiculosus and Bifurcaria bifurcata) and Micro-Algae (Chlorella vulgaris and Spirulina platensis) Assisted by Ultrasound. Medicines 2018, 5, 33. [CrossRef]

316. Dantas, D.M.M.; Oliveira, C.Y.B.; Costa, R.M.P.B.; Carneiro-da-Cunha, M.D.G.; Gálvez, A.O.; Bezerra, R.S. Evaluation of antioxidant and antibacterial capacity of green microalgae Scenedesmus subspicatus. Food Sci. Technol. Int. 2019, 25, 318-326. [CrossRef]

317. Sansone, C.; Galasso, C.; Orefice, I.; Nuzzo, G.; Luongo, E.; Cutignano, A.; Romano, G.; Brunet, C.; Fontana, A.; Esposito, F.; et al. The green microalga Tetraselmis suecica reduces oxidative stress and induces repairing mechanisms in human cells. Sci. Rep. 2017, 7, 41215. [CrossRef]

318. Kato, S.; Kawasaki, T.; Urata, T.; Mochizuki, J. In vitro and ex vivo free radical scavenging activities of carazostatin, carbazomycin $\mathrm{b}$ and their derivatives. J. Antibiot. 1993, 46, 1859-1865. [CrossRef]

319. Shin-Ya, K.; Imai, S.; Furihata, K.; Hayakawa, K.; Hayakawa, Y.; Kato, Y.; Vanduyne, G.D.; Clardy, J.; Seto, H. Isolation and structural elucidation of an antioxidative agent, naphterpin. J. Antibiot. 1990, 43, 444-447. [CrossRef]

320. Karthik, L.; Kumar, G.; Rao, K.V.B. Antioxidant activity of newly discovered lineage of marine actinobacteria. Asian Pac. J. Trop. Med. 2013, 6, 325-332. [CrossRef]

321. Boisselier, E.; Astruc, D. Gold nanoparticles in nanomedicine: Preparations, imaging, diagnostics, therapies and toxicity. Chem. Soc. Rev. 2009, 38, 1759-1782. [CrossRef]

322. Eftekhari, A.; Dizaj, S.M.; Chodari, L.; Sunar, S.; Hasanzadeh, A.; Ahmadian, E.; Hasanzadeh, M. The promising future of nano-antioxidant therapy against environmental pollutants induced-toxicities. Biomed. Pharmacother. 2018, 103, 1018-1027. [CrossRef]

323. Nelson, B.C.; Johnson, M.E.; Walker, M.L.; Riley, K.R.; Sims, C.M. Antioxidant Cerium Oxide Nanoparticles in Biology and Medicine. Antioxidants 2016, 5, 15. [CrossRef] [PubMed]

324. Herlekar, M.; Barve, S.; Kumar, R. Plant-mediated green synthesis of iron nanoparticles. J. Nanopart. Res. 2014, $2014,140614$. [CrossRef]

325. Huber, D.L. Synthesis, properties, and applications of iron nanoparticles. Small 2005, 1, 482-501. [CrossRef]

326. Guo, J.; Wang, R.; Tjiu, W.W.; Pan, J.; Liu, T. Synthesis of Fe nanoparticles@ graphene composites for environmental applications. J. Hazard. Mater. 2012, 225, 63-73. [CrossRef] [PubMed]

327. Ebrahiminezhad, A.; Zare-Hoseinabadi, A.; Sarmah, A.K.; Taghizadeh, S.; Ghasemi, Y.; Berenjian, A. Plant-mediated synthesis and applications of iron nanoparticles. Mol. Biotechnol. 2018, 60, 154-168. [CrossRef] [PubMed]

328. Kumar, H.; Bhardwaj, K.; Kuča, K.; Kalia, A.; Nepovimova, E.; Verma, R.; Kumar, D. Flower-Based Green Synthesis of Metallic Nanoparticles: Applications beyond Fragrance. Nanomaterials 2020, 10, 766. [CrossRef]

329. Henriksen-Lacey, M.; Carregal-Romero, S.; Liz-Marzán, L.M. Current Challenges toward In Vitro Cellular Validation of Inorganic Nanoparticles. Bioconjug. Chem. 2017, 28, 212-221. [CrossRef]

330. Ariga, K.; Minami, K.; Ebara, M.; Nakanishi, J. What are the emerging concepts and challenges in NANO Nanoarchitectonics, hand-operating nanotechnology and mechanobiology. Polym. J. 2016, 48, 371-389. [CrossRef]

331. Jessl, S.; Tebbe, M.; Guerrini, L.; Fery, A.; Alvarez-Puebla, R.A.; Pazos-Perez, N. Silver-Assisted Synthesis of Gold Nanorods: The Relation between Silver Additive and Iodide Impurities. Small 2018, 14, e1703879. [CrossRef] [PubMed]

332. Boström, M.; Williams, D.R.; Ninham, B.W. Specific ion effects: Why DLVO theory fails for biology and colloid systems. Phys. Rev. Lett. 2001, 87, 168103. [CrossRef] [PubMed]

333. Nel, A.; Xia, T.; Mädler, L.; Li, N. Toxic potential of materials at the nanolevel. Science 2006, 311, 622-627. [CrossRef] 
334. Oberdörster, G.; Oberdörster, E.; Oberdörster, J. Nanotoxicology: An emerging discipline evolving from studies of ultrafine particles. Environ. Health Perspect. 2005, 113, 823-839. [CrossRef]

335. Gurunathan, S.; Jeyaraj, M.; La, H.; Yoo, H.; Choi, Y.; Do, J.T.; Park, C.; Kim, J.H.; Hong, K. Anisotropic Platinum NanoparticleInduced Cytotoxicity, Apoptosis, Inflammatory Response, and Transcriptomic and Molecular Pathways in Human Acute Monocytic Leukemia Cells. Int. J. Mol. Sci. 2020, 21, 440. [CrossRef] [PubMed]

336. Giordo, R.; Nasrallah, G.K.; Al-Jamal, O.; Paliogiannis, P.; Pintus, G. Resveratrol Inhibits Oxidative Stress and Prevents Mitochondrial Damage Induced by Zinc Oxide Nanoparticles in Zebrafish (Danio rerio). Int. J. Mol. Sci. 2020, 21, 3838. [CrossRef] [PubMed]

337. Zhou, X.; Zhao, L.; Luo, J.; Tang, H.; Xu, M.; Wang, Y.; Yang, X.; Chen, H.; Li, Y.; Ye, G.; et al. The Toxic Effects and Mechanisms of Nano-Cu on the Spleen of Rats. Int. J. Mol. Sci. 2019, 20, 1469. [CrossRef]

338. Khanna, P.; Ong, C.; Bay, B.H.; Baeg, G.H. Nanotoxicity: An Interplay of Oxidative Stress, Inflammation and Cell Death. Nanomaterials 2015, 5, 1163-1180. [CrossRef] [PubMed]

339. Fubini, B.; Hubbard, A. Reactive oxygen species (ROS) and reactive nitrogen species (RNS) generation by silica in inflammation and fibrosis. Free Radic. Biol. Med. 2003, 34, 1507-1516. [CrossRef]

340. Manke, A.; Wang, L.; Rojanasakul, Y. Mechanisms of nanoparticle-induced oxidative stress and toxicity. Biomed. Res. Int. 2013, 2013, 942916. [CrossRef]

341. Sims, C.M.; Hanna, S.K.; Heller, D.A.; Horoszko, C.P.; Johnson, M.E.; Montoro Bustos, A.R.; Reipa, V.; Riley, K.R.; Nelson, B.C. Redox-active nanomaterials for nanomedicine applications. Nanoscale 2017, 9, 15226-15251. [CrossRef]

342. Schubert, D.; Dargusch, R.; Raitano, J.; Chan, S.W. Cerium and yttrium oxide nanoparticles are neuroprotective. Biochem. Biophys. Res. Commun. 2006, 342, 86-91. [CrossRef]

343. Chen, J.; Patil, S.; Seal, S.; McGinnis, J.F. Rare earth nanoparticles prevent retinal degeneration induced by intracellular peroxides. Nat. Nanotechnol. 2006, 1, 142-150. [CrossRef] [PubMed]

344. Das, M.; Patil, S.; Bhargava, N.; Kang, J.F.; Riedel, L.M.; Seal, S.; Hickman, J.J. Auto-catalytic ceria nanoparticles offer neuroprotection to adult rat spinal cord neurons. Biomaterials 2007, 28, 1918-1925. [CrossRef]

345. Korsvik, C.; Patil, S.; Seal, S.; Self, W.T. Superoxide dismutase mimetic properties exhibited by vacancy engineered ceria nanoparticles. Chem. Commun. 2007, 10, 1056-1058. [CrossRef] [PubMed]

346. Reidy, B.; Haase, A.; Luch, A.; Dawson, K.A.; Lynch, I. Mechanisms of Silver Nanoparticle Release, Transformation and Toxicity: A Critical Review of Current Knowledge and Recommendations for Future Studies and Applications. Materials 2013, 6, 2295-2350. [CrossRef] [PubMed]

347. AshaRani, P.V.; Low Kah Mun, G.; Hande, M.P.; Valiyaveettil, S. Cytotoxicity and genotoxicity of silver nanoparticles in human cells. ACS Nano 2009, 3, 279-290. [CrossRef] [PubMed]

348. Hirst, S.M.; Karakoti, A.; Singh, S.; Self, W.; Tyler, R.; Seal, S.; Reilly, C.M. Bio-distribution and in vivo antioxidant effects of cerium oxide nanoparticles in mice. Environ. Toxicol. 2013, 28, 107-118. [CrossRef]

349. Caputo, F.; De Nicola, M.; Sienkiewicz, A.; Giovanetti, A.; Bejarano, I.; Licoccia, S.; Traversa, E.; Ghibelli, L. Cerium oxide nanoparticles, combining antioxidant and UV shielding properties, prevent UV-induced cell damage and mutagenesis. Nanoscale 2015, 7, 15643-15656. [CrossRef]

350. Koul, B.; Poonia, A.K.; Yadav, D.; Jin, J.-O. Microbe-Mediated Biosynthesis of Nanoparticles: Applications and Future Prospects. Biomolecules 2021, 11, 886. [CrossRef]

351. Garmasheva, I.; Kovalenko, N.; Voychuk, S.; Ostapchuk, A.; Livins'ka, O.; Oleschenko, L. Lactobacillus species mediated synthesis of silver nanoparticles and their antibacterial activity against opportunistic pathogens in vitro. BioImpacts 2016, 6, 219-223. [CrossRef]

352. Vu, X.H.; Duong, T.T.T.; Pham, T.T.H.; Trinh, D.K.; Nguyen, X.H.; Dang, V.-S. Synthesis and study of silver nanoparticles for antibacterial activity against Escherichia coli and Staphylococcus aureus. Adv. Nat. Sci. Nanosci. Nanotechnol. 2018, 9, 025019. [CrossRef]

353. Rai, M.; Yadav, A.; Gade, A. Silver nanoparticles as a new generation of antimicrobials. Biotechnol. Adv. 2009, 27, 76-83. [CrossRef]

354. Lemire, J.A.; Harrison, J.J.; Turner, R.J. Antimicrobial activity of metals: Mechanisms, molecular targets and applications. Nat. Rev. Microbiol. 2013, 11, 371-384. [CrossRef]

355. Lok, C.N.; Ho, C.M.; Chen, R.; He, Q.Y.; Yu, W.Y.; Sun, H.; Tam, P.K.; Chiu, J.F.; Che, C.M. Silver nanoparticles: Partial oxidation and antibacterial activities. J. Biol. Inorg. Chem. 2007, 12, 527-534. [CrossRef]

356. Percival, S.L.; Hill, K.E.; Williams, D.W.; Hooper, S.J.; Thomas, D.W.; Costerton, J.W. A review of the scientific evidence for biofilms in wounds. Wound Repair. Regen. 2012, 20, 647-657. [CrossRef]

357. Rendueles, O.; Ghigo, J.M. Multi-species biofilms: How to avoid unfriendly neighbors. FEMS Microbiol. Rev. 2012, 36, 972-989. [CrossRef]

358. Donlan, R.M.; Costerton, J.W. Biofilms: Survival mechanisms of clinically relevant microorganisms. Clin. Microbiol. Rev. 2002, 15, 167-193. [CrossRef]

359. Mah, T.F.; O'Toole, G.A. Mechanisms of biofilm resistance to antimicrobial agents. Trends Microbiol. 2001, 9, 34-39. [CrossRef]

360. Kakoullis, L.; Papachristodoulou, E.; Chra, P.; Panos, G. Mechanisms of Antibiotic Resistance in Important Gram-Positive and Gram-Negative Pathogens and Novel Antibiotic Solutions. Antibiotics 2021, 10, 415. [CrossRef] 
361. Amanatidou, E.; Matthews, A.C.; Kuhlicke, U.; Neu, T.R.; McEvoy, J.P.; Raymond, B. Biofilms facilitate cheating and social exploitation of $\beta$-lactam resistance in Escherichia coli. NPJ Biofilms Microbiomes 2019, 5. [CrossRef] [PubMed]

362. Kalishwaralal, K.; Barath Mani Kanth, S.; Pandian, S.R.K.; Deepak, V.; Gurunathan, S. Silver nanoparticles impede the biofilm formation by Pseudomonas aeruginosa and Staphylococcus epidermidis. Colloids Sur. B Biointerfaces 2010, 79, 340-344. [CrossRef]

363. Siddique, M.H.; Aslam, B.; Imran, M.; Ashraf, A.; Nadeem, H.; Hayat, S.; Khurshid, M.; Afzal, M.; Malik, I.R.; Shahzad, M.; et al. Effect of Silver Nanoparticles on Biofilm Formation and EPS Production of Multidrug-Resistant Klebsiella pneumoniae. Biomed. Res. Int. 2020, 2020, 6398165. [CrossRef] [PubMed]

364. Hamida, R.S.; Ali, M.A.; Goda, D.A.; Khalil, M.I.; Al-Zaban, M.I. Novel Biogenic Silver Nanoparticle-Induced Reactive Oxygen Species Inhibit the Biofilm Formation and Virulence Activities of Methicillin-Resistant Staphylococcus aureus (MRSA) Strain. Front. Bioeng. Biotechnol. 2020, 8. [CrossRef]

365. Jafari, A.; Nagheli, A.; Alavi Foumani, A.; Soltani, B.; Goswami, R. The Role of Metallic Nanoparticles in Inhibition of Mycobacterium Tuberculosis and Enhances Phagosome Maturation into the Infected Macrophage. Oman Med. J. 2020, 35 , e194. [CrossRef]

366. Li, X.; Sun, L.; Zhang, P.; Wang, Y. Novel Approaches to Combat Medical Device-Associated BioFilms. Coatings 2021, 11, 294. [CrossRef]

367. Liu, Z.; Liu, X.; Ramakrishna, S. Surface engineering of biomaterials in orthopedic and dental implants: Strategies to improve osteointegration, bacteriostatic and bactericidal activities. Biotechnol. J. 2021, e2000116. [CrossRef] [PubMed]

368. Filipović, U.; Dahmane, R.G.; Ghannouchi, S.; Zore, A.; Bohinc, K. Bacterial adhesion on orthopedic implants. Adv. Colloid Interface Sci. 2020, 283, 102228. [CrossRef]

369. Chouirfa, H.; Bouloussa, H.; Migonney, V.; Falentin-Daudré, C. Review of titanium surface modification techniques and coatings for antibacterial applications. Acta Biomater. 2019, 83, 37-54. [CrossRef]

370. Wang, N.; Fuh, J.Y.H.; Dheen, S.T.; Senthil Kumar, A. Functions and applications of metallic and metallic oxide nanoparticles in orthopedic implants and scaffolds. J. Biomed. Mater. Res. B Appl. Biomater. 2021, 109, 160-179. [CrossRef]

371. Sukhanova, A.; Bozrova, S.; Sokolov, P.; Berestovoy, M.; Karaulov, A.; Nabiev, I. Dependence of Nanoparticle Toxicity on Their Physical and Chemical Properties. Nanoscale Res. Lett. 2018, 13, 44. [CrossRef]

372. Alphandéry, E. Natural Metallic Nanoparticles for Application in Nano-Oncology. Int. J. Mol. Sci. 2020, 21, 4412. [CrossRef]

373. Alphandéry, E. Bio-synthesized iron oxide nanoparticles for cancer treatment. Int. J. Pharm. 2020, 586, 119472. [CrossRef] [PubMed]

374. Fdez-Gubieda, M.L.; Alonso, J.; García-Prieto, A.; García-Arribas, A.; Barquín, L.F.; Muela, A. Magnetotactic bacteria for cancer therapy. J. Appl. Phys. 2020, 128, 070902. [CrossRef]

375. Bai, Y.; Qiu, X.; Zhang, Q.; Qiu, S.; Qin, Y.; Wang, T. Green Synthesis of Highly Dispersed Ni/SiO2 Catalysts Using Natural Biomass of Sesbania Powder. Ind. Eng. Chem. Res. 2020, 59, 17399-17407. [CrossRef]

376. Nasrullah, M.; Gul, F.Z.; Hanif, S.; Mannan, A.; Naz, S.; Ali, J.S.; Zia, M. Green and Chemical Syntheses of CdO NPs: A Comparative Study for Yield Attributes, Biological Characteristics, and Toxicity Concerns. ACS Omega 2020, 5, 5739-5747. [CrossRef]

377. Sriranjani, R.; Srinithya, B.; Vellingiri, V.; Brindha, P.; Anthony, S.P.; Sivasubramanian, A.; Muthuraman, M.S. Silver nanoparticle synthesis using Clerodendrum phlomidis leaf extract and preliminary investigation of its antioxidant and anticancer activities. $J$. Mol. Liq. 2016, 220, 926-930. [CrossRef]

378. Misawa, M.; Takahashi, J. Generation of reactive oxygen species induced by gold nanoparticles under X-ray and UV Irradiations. Nanomedicine 2011, 7, 604-614. [CrossRef]

379. Avalos, A.; Haza, A.I.; Mateo, D.; Morales, P. Cytotoxicity and ROS production of manufactured silver nanoparticles of different sizes in hepatoma and leukemia cells. J. Appl. Toxicol. 2014, 34, 413-423. [CrossRef]

380. Flores-López, L.Z.; Espinoza-Gómez, H.; Somanathan, R. Silver nanoparticles: Electron transfer, reactive oxygen species, oxidative stress, beneficial and toxicological effects. Mini review. J. Appl. Toxicol. 2019, 39, 16-26. [CrossRef]

381. Chithrani, B.D.; Ghazani, A.A.; Chan, W.C. Determining the size and shape dependence of gold nanoparticle uptake into mammalian cells. Nano. Lett. 2006, 6, 662-668. [CrossRef]

382. Rajeshkumar, S.; Menon, S.; Kumar, S.V.; Tambuwala, M.M.; Bakshi, H.A.; Mehta, M.; Satija, S.; Gupta, G.; Chellappan, D.K.; Thangavelu, L.; et al. Antibacterial and antioxidant potential of biosynthesized copper nanoparticles mediated through Cissus arnotiana plant extract. J. Photochem. Photobiol. 2019, 197, 111531. [CrossRef] [PubMed]

383. Muthukumar, H.; Manickam, M. Amaranthus spinosus leaf extract mediated FeO nanoparticles: Physicochemical traits, photocatalytic and antioxidant activity. ACS Sustain. Chem. Eng. 2015, 3, 3149-3156. [CrossRef]

384. Babay, S.; Mhiri, T.; Toumi, M. Synthesis, structural and spectroscopic characterizations of maghemite-Fe ${ }_{2} \mathrm{O}_{3}$ prepared by one-step coprecipitation route. J. Mol. Struct. 2015, 1085, 286-293. [CrossRef]

385. Saleh, N.; Kim, H.J.; Phenrat, T.; Matyjaszewski, K.; Tilton, R.D.; Lowry, G.V. Ionic strength and composition a_ect the mobility of surface-modified Fe0 nanoparticles in water-saturated sand columns. Environ. Sci. Technol. 2008, 42, 3349-3355. [CrossRef]

386. Kim, H.J.; Kim, D.G.; Yoon, H.; Choi, Y.S.; Yoon, J.; Lee, J.C. Polyphenol/FeIII complex coated membranes having multifunctional properties prepared by a one-step fast assembly. Adv. Mater. Interfaces 2015, 2, 1500298. [CrossRef] 
387. Yang, L.; Cao, Z.; Sajja, H.K.; Mao, H.; Wang, L.; Geng, H.; Xu, H.; Jiang, T.; Wood, W.C.; Nie, S.; et al. Development of receptor targeted magnetic iron oxide nanoparticles for effcient drug delivery and tumor imaging. J. Biomed. Nanotechnol. 2008, 4, 439-449. [CrossRef] [PubMed]

388. Akhtar, M.S.; Panwar, J.; Yun, Y.S. Biogenic Synthesis of Metallic Nanoparticles by Plant Extracts. ACS Sustain. Chem. Eng. 2013, 1, 591-602. [CrossRef]

389. Gericke, M.; Pinches, A. Biological synthesis of metal nanoparticles. Hydrometallurgy 2006, 83, 132-140. [CrossRef]

390. Suresh, A.K.; Pelletier, D.A.; Wang, W.; Broich, M.L.; Moon, J.W.; Gu, B.; Allison, D.P.; Joy, D.C.; Phelps, T.J.; Doktycz, M.J. Biofabrication of discrete spherical gold nanoparticles using the metal-reducing bacterium Shewanella oneidensis. Acta Biomater. 2011, 7, 2148-2152. [CrossRef]

391. Grzelczak, M.; Pérez-Juste, J.; Mulvaney, P.; Liz-Marzán, L.M. Shape control in gold nanoparticle synthesis. Chem. Soc. Rev. 2008, 37, 1783-1791. [CrossRef] [PubMed]

392. Patil, S.P.; Kumbhar, S.T. Antioxidant, antibacterial and cytotoxic potential of silver nanoparticles synthesized using terpenes rich extract of Lantana camara L. leaves. Biochem. Biophys. Rep. 2017, 10, 76-81. [CrossRef]

393. Elemike, E.E.; Fayemi, O.E.; Ekennia, A.C.; Onwudiwe, D.C.; Ebenso, E.E. Silver Nanoparticles Mediated by Costus afer Leaf Extract: Synthesis, Antibacterial, Antioxidant and Electrochemical Properties. Molecules 2017, 22, 701. [CrossRef]

394. Saratale, R.G.; Benelli, G.; Kumar, G.; Kim, D.S.; Saratale, G.D. Bio-fabrication of silver nanoparticles using the leaf extract of an ancient herbal medicine, dandelion (Taraxacum o_cinale), evaluation of their antioxidant, anticancer potential, and antimicrobial activity against phytopathogens. Environ. Sci. Pollut. Res. 2018, 25, 10392-10406. [CrossRef]

395. Das, D.; Ghosh, R.; Mandal, P. Biogenic synthesis of silver nanoparticles using S1 genotype of Morus alba leaf extract: Characterization, antimicrobial and antioxidant potential assessment. SN Appl. Sci. 2019, 1, 498. [CrossRef]

396. Hamelian, M.; Zangeneh, M.M.; Amisama, A.; Varmira, K.; Veisi, H. Green synthesis of silver nanoparticlesusing Thymus kotschyanus extract and evaluation of their antioxidant, antibacterial and cytotoxic effects. Appl. Organomet. Chem. 2018, 32 , e4458. [CrossRef]

397. Keshari, A.K.; Srivastava, R.; Singh, P.; Yadav, V.B.; Nath, G. Antioxidant and antibacterial activity of silver nanoparticles synthesized by Cestrum nocturnum. J. Ayurveda Integr. Med. 2020, 11, 37-44. [CrossRef]

398. Shanmugasundaram, T.; Radhakrishnan, M.; Gopikrishnan, V.; Pazhanimurugan, R.; Balagurunathan, R. A study of the bactericidal, anti-biofouling, cytotoxic and antioxidant properties of actinobacterially synthesised silver nanoparticles. Colloids Surf. B Biointerfaces 2013, 111, 680-687. [CrossRef]

399. Dasari, S.; Suresh, K.A.; Rajesh, M.; Reddy, C.S.S.; Hemalatha, C.S.; Wudayagiri, R.; Valluru, L. Biosynthesis, characterization, antibacterial and antioxidant activity of silver nanoparticles produced by lichens. J. Bionanosci. 2013, 7, 237-244. [CrossRef]

400. Venkatesan, J.; Kim, S.K.; Shim, S.K. Antimicrobial, antioxidant, and anticancer activities of biosynthesized silver nanoparticles using marine algae Ecklonia cava. Nanomaterials 2016, 6, 235. [CrossRef] [PubMed]

401. Netala, V.R.; Bethu, M.S.; Pushpalatha, B.; Baki, V.B.; Aishwarya, S.; Rao, J.V.; Tartte, V. Biogenesis of silver nanoparticles using endophytic fungus Pestalotiopsis microspora and evaluation of their antioxidant and anticancer activities. Int. J. Nanomed. 2016, 11, 5683-5696. [CrossRef]

402. Manjunath, H.M.; Joshi, C.G.; Danagoudar, A.; Poyya, J.; Kudva, A.K.; Dhananjaya, B.L. Biogenic synthesis of gold nanoparticles by marine endophytic fungus-Cladosporium cladosporioides isolated from seaweed and evaluation of their antioxidant and antimicrobial properties. Process Biochem. 2017, 63, 137-144. [CrossRef]

403. Netala, V.R.; Kotakadi, V.S.; Bobbu, P.; Gaddam, S.A.; Tartte, V. Endophytic fungal isolate mediated biosynthesis of silver nanoparticles and their free radical scavenging activity and anti microbial studies. 3 Biotech 2016, 6, 132. [CrossRef]

404. Saravanakumar, K.; Wang, M.H. Trichoderma based synthesis of anti-pathogenic silver nanoparticles and their characterization, antioxidant and cytotoxicity properties. Microb. Pathog. 2018, 114, 269-273. [CrossRef]

405. Govindappa, M.; Farheen, H.; Chandrappa, C.P.; Rai, R.V.; Raghavendra, V.B. Mycosynthesis of silver nanoparticles using extract of endophytic fungi, Penicillium species of Glycosmis mauritiana, and its antioxidant, antimicrobial, anti-inflammatory and tyrokinase inhibitory activity. Adv. Nat. Sci. Nanosci. Nanotechnol. 2016, 7, 035014. [CrossRef]

406. Nagajyothi, P.C.; Sreekanth, T.V.M.; Lee, J.I.; Lee, K.D. Mycosynthesis: Antibacterial, antioxidant and antiproliferative activities of silver nanoparticles synthesized from Inonotus obliquus (Chaga mushroom) extract. J. Photochem. Photobiol. B 2014, 130, $299-304$. [CrossRef]

407. Popli, D.; Anil, V.; Subramanyam, A.B.; Namratha, M.N.; Ranjitha, V.R.; Rao, S.N.; Rai, R.V.; Govindappa, M. Endophyte fungi, Cladosporium species-mediated synthesis of silver nanoparticles possessing in vitro antioxidant, anti-diabetic and anti-Alzheimer activity. Artif. Cells Nanomed. Biotechnol. 2018, 46, 676-683. [CrossRef]

408. Sriramulu, M.; Sumathi, S. Photocatalytic, antioxidant, antibacterial and anti-inflammatory activity of silver nanoparticles synthesised using forest and edible mushroom. Adv. Nat. Sci. Nanosci. Nanotechnol. 2017, 8, 045012. [CrossRef]

409. Aygün, A.; Özdemir, S.; Gülcan, M.; Cellat, K.; Sen, F. Synthesis and characterization of Reishi mushroom-mediated green synthesis of silver nanoparticles for the biochemical applications. J. Pharm. Bimed. Anal. 2020, 178, 112970. [CrossRef] [PubMed]

410. Poudel, M.; Pokharel, R.; Sudip, K.C.; Awal, S.C.; Pradhananga, R. Biosynthesis of silver nanoparticles using Ganoderma Lucidum and assessment of antioxidant and antibacterial activity. Int. J. Appl. Sci. Biotechnol. 2017, 5, 523-531. [CrossRef]

411. Baygar, T.; Ugur, A. Biosynthesis of silver nanoparticles by Streptomyces griseorubens isolated from soil and their antioxidant activity. IET Nanobiotechnol. 2017, 11, 286-291. [CrossRef] 
412. Ungureanu, C.; Fierascu, I.; Fierascu, R.C.; Costea, T.; Avramescu, S.M.; Călinescu, M.F.; Somoghi, R.; Pirvu, C. In Vitro and In Vivo Evaluation of Silver Nanoparticles Phytosynthesized Using Raphanus sativus L. Waste Extracts. Materials 2021, $14,1845$. [CrossRef] [PubMed]

413. Debnath, R.; Purkayastha, D.D.; Hazra, S.; Ghosh, N.N.; Bhattacharjee, C.R.; Rout, J. Biogenic synthesis of antioxidant, shape selective gold nanomaterials mediated by high altitude lichens. Mater. Lett. 2016, 169, 58-61. [CrossRef]

414. Shakibaie, M.; Forootanfar, H.; Mollazadeh-Moghaddam, K.; Bagherzadeh, Z.; Nafissi-Varcheh, N.; Shahverdi, A.R.; Faramarzi, M.A.J.B.; Biochemistry, A. Green synthesis of gold nanoparticles by the marine microalga Tetraselmis suecica. Biotechnol. Appl. Biochem. 2010, 57, 71-75. [CrossRef] [PubMed]

415. Veeraapandian, S.; Sawant, S.N.; Doble, M. Antibacterial and antioxidant activity of protein capped silver and gold nanoparticles synthesized with Escherichia coli. J. Biomed. Nanotechnol. 2012, 8, 140-148. [CrossRef]

416. Ramamurthy, C.H.; Padma, M.; Samadanam, I.D.; Mareeswaran, R.; Suyavaran, A.; Kumar, M.S.; Premkumar, K.; Thirunavukkarasu, C. The extra cellular synthesis of gold and silver nanoparticles and their free radical scavenging and antibacterial properties. Colloids Surf. B Biointerfaces 2013, 102, 808-815. [CrossRef] [PubMed]

417. Parial, D.; Patra, H.K.; Dasgupta, A.K.; Pal, R. Screening of different algae for green synthesis of gold nanoparticles. Eur. J. Phycol. 2012, 47, 22-29. [CrossRef]

418. Lee, K.D.; Nagajyothi, P.C.; Sreekanth, T.V.M.; Park, S. Eco-friendly synthesis of gold nanoparticles (AuNPs) using Inonotus obliquus and their antibacterial, antioxidant and cytotoxic activities. J. Ind. Eng. Chem. 2015, 26, 67-72. [CrossRef]

419. Markus, J.; Mathiyalagan, R.; Kim, Y.J.; Abbai, R.; Singh, P.; Ahn, S.; Perez, Z.E.J.; Hurh, J.; Yang, D.C. Intracellularsynthesis of goldnanoparticles with antioxidantactivity by probiotic Lactobacillus kimchicus DCY51T isolated from Koreankimchi. Enzym. Microb. Technol. 2016, 95, 85-93. [CrossRef]

420. Oladipo, I.C.; Lateef, A.; Elegbede, J.A.; Azeez, M.A.; Asafa, T.M.; Yekeen, T.A.; Akinboro, A.; Gueguim-Kana, E.B.; Beukes, L.S.; Oluyide, T.O.; et al. Enterococcus species for the one-pot biofabrication of gold nanoparticles: Characterization and nanobiotechnological applications. J. Photochem. Photobiol. B 2017, 173, 250-257. [CrossRef] [PubMed]

421. Singaravelu, G.; Arockiamary, J.; Kumar, V.G.; Govindaraju, K. A novel extracellular synthesis of monodisperse gold nanoparticles using marine alga, Sargassum wightii Greville. Colloids Surf. B Biointerfaces 2007, 57, 97-101. [CrossRef]

422. Kalabegishvili, T.; Kirkesali, E.I.; Rcheulishvili, A.N.; Ginturi, E.; Murusidze, I.; Kuchava, N.; Bagdavadze, N.; Tsertsvadze, G.; Gabunia, V.; Frontasyeva, M.; et al. Synthesis of gold nanoparticles by blue-green algae Spirulina platensis. Adv. Sci. Eng. Med. 2012, 4, 1-7.

423. Veena, S.; Devasena, T.; Sathak, S.S.M.; Yasasve, M.; Vishal, L.A. Green synthesis of gold nanoparticles from Vitex negundo leaf extract: Characterization and in vitro evaluation of antioxidant-antibacterial activity. J. Clust. Sci. 2019, 30, 1591-1597. [CrossRef]

424. Moghaddam, A.B.; Moniri, M.; Azizi, S.; Rahim, R.A.; Ari_, A.B.; Saad, W.Z.; Namvar, F.; Navaderi, M.; Mohamad, R. Biosynthesis of $\mathrm{ZnO}$ nanoparticles by a new Pichia kudriavzevii yeast strain and evaluation of their antimicrobial and antioxidant activities. Molecules 2017, 22, 872. [CrossRef]

425. Chandra, H.; Patel, D.; Kumari, P.; Jangwan, J.S.; Yadav, S. Phyto-mediated synthesis of zinc oxide nanoparticles of Berberis aristata: Characterization, antioxidant activity and antibacterial activity with special reference to urinary tract pathogens. Mater. Sci. Eng. C Mater. Biol. Appl. 2019, 102, 212-220. [CrossRef] [PubMed]

426. Ramya, S.; Shanmugasundaram, T.; Balagurunathan, R. Biomedical potential of actinobacterially synthesized selenium nanoparticles with special reference to anti-biofilm, anti-oxidant, wound healing, cytotoxic and anti-viral activities. J. Trace Elem. Med. Biol. 2015, 32, 30-39. [CrossRef] [PubMed]

427. Torres, S.K.; Campos, V.L.; León, C.G.; Rodríguez-Llamazares, S.M.; Rajos, S.M.; González, M.; Smith, C.; Mondaca, M.A. Biosynthesis of selenium nanoparticles by Pantoea agglomerans and their antioxidant activity. J. Nanopart. Res. 2012, $14,1236$. [CrossRef]

428. El-Zayat, M.M.; Eraqi, M.M.; Alrefai, H.; El-Khateeb, A.Y.; Ibrahim, M.A.; Aljohani, H.M.; Aljohani, M.M.; Elshaer, M.M. The Antimicrobial, Antioxidant, and Anticancer Activity of Greenly Synthesized Selenium and Zinc Composite Nanoparticles Using Ephedra aphylla Extract. Biomolecules 2021, 11, 470. [CrossRef]

429. Ghosh, S.; More, P.; Nitnavare, R.; Jagtap, S.; Chippalkatti, R.; Derle, A.; Kitture, R.; Asok, A.; Kale, S.; Singh, S.; et al. Antidiabetic and antioxidant properties of copper nanoparticles synthesized by medicinal plant Dioscorea bulbifera. J. Nanomed. Nanotechnol. 2015, S6, 007. [CrossRef]

430. Sarkar, J.; Chakraborty, N.; Chatterjee, A.; Bhattacharjee, A.; Dasgupta, D.; Acharya, K. Green synthesized copper oxide nanoparticles ameliorate defence and antioxidant enzymes in Lens culinaris. Nanomaterials 2020, 10, 312. [CrossRef] [PubMed]

431. Dobrucka, R. Antioxidant and catalytic activity of biosynthesized CuO nanoparticles using extract of Galeopsidis herba. J. Inorg. Organomet. Polym. Mater. 2018, 28, 812-819. [CrossRef]

432. Keabadile, O.P.; Aremu, A.O.; Elugoke, S.E.; Fayemi, O.E. Green and Traditional Synthesis of Copper Oxide NanoparticlesComparative Study. Nanomaterials 2020, 10, 2502. [CrossRef]

433. Harshiny, M.; Iswarya, C.N.; Matheswaran, M. Biogenic synthesis of iron nanoparticles using Amaranthus dubius leaves extract as reducing agents. Powder Technol. 2015, 286, 744-749. [CrossRef]

434. Tuzun, B.S.; Fafal, T.; Tastan, P.; Kivcak, B.; Yelken, B.O.; Kayabasi, C.; Susluer, S.Y.; Gunduz, C. Structural characterization, antioxidant and cytotoxic e_ects of iron nanoparticles synthesized using Asphodelus aestivus Brot. aqueous extract. Green Process. Synth. 2020, 9, 153-163. [CrossRef] 
435. Srihasam, S.; Thyagarajan, K.; Korivi, M.; Lebaka, V.R.; Mallem, S.P.R. Phytogenic generation of NiO nanoparticles using Stevia leaf extract and evaluation of their in-vitro antioxidant and antimicrobial properties. Biomolecules 2020, 10, 89. [CrossRef]

436. Uddin, S.; Safdar, L.B.; Anwar, S.; Iqbal, J.; Laila, S.; Abbasi, B.A.; Saif, M.S.; Ali, M.; Rehman, A.; Basit, A.; et al. Green Synthesis of Nickel Oxide Nanoparticles from Berberis balochistanica Stem for Investigating Bioactivities. Molecules 2021, 26, 1548. [CrossRef] [PubMed]

437. Paul, J.J.P.; Sakunthala, M.; Udhaya, I. Green synthesis of Manganese nanoparticles using the aqueous extract of Ctenolepis garcini (Burm. f.) C.B Clarke. Int. J. Bot. Stud. 2017, 2, 71-75.

438. Khan, S.A.; Shahid, S.; Shahid, B.; Fatima, U.; Abbasi, S.A. Green Synthesis of MnO Nanoparticles Using Abutilon indicum Leaf Extract for Biological, Photocatalytic, and Adsorption Activities. Biomolecules 2020, 10, 785. [CrossRef]

439. Fouda, A.; Awad, M.A.; Eid, A.M.; Saied, E.; Barghoth, M.G.; Hamza, M.F.; Awad, M.F.; Abdelbary, S.; Hassan, S.E.-D. An Eco-Friendly Approach to the Control of Pathogenic Microbes and Anopheles stephensi Malarial Vector Using Magnesium Oxide Nanoparticles (Mg-NPs) Fabricated by Penicillium chrysogenum. Int. J. Mol. Sci. 2021, 22, 5096. [CrossRef] [PubMed]

440. Konopko, A.; Kusio, J.; Litwinienko, G. Antioxidant Activity of Metal Nanoparticles Coated with Tocopherol-Like Residues-The Importance of Studies in Homo- and Heterogeneous Systems. Antioxidants 2019, 9, 5. [CrossRef] [PubMed]

441. Nie, Z.; Liu, K.J.; Zhong, C.J.; Wang, L.F.; Yang, Y.; Tian, Q.; Liu, Y. Enhanced radical scavenging activity by antioxidantfunctionalized gold nanoparticles: A novel inspiration for development of new artificial antioxidants. Free Radic. Biol. Med. 2007, 43, 1243-1254. [CrossRef]

442. Esumi, K.; Takei, N.; Yoshimura, T. Antioxidant-potentiality of gold-chitosan nanocomposites. Colloids Surf. B Biointerfaces 2003, 32, 117-123. [CrossRef]

443. Baruwati, B.; Polshettiwar, V.; Varma, R.S. Glutathione promoted expeditious green synthesis of silver nanoparticles in water using microwaves. Green Chem. 2009, 11, 926-930. [CrossRef]

444. Viglianisi, C.; Di Pilla, V.; Menichetti, S.; Rotello, V.M.; Candiani, G.; Malloggi, C.; Amorati, R. Linking an $\alpha$-tocopherol derivative to cobalt $(0)$ nanomagnets: Magnetically responsive antioxidants with superior radical trapping activity and reduced cytotoxicity. Chemistry 2014, 20, 6857-6860. [CrossRef] [PubMed]

445. Mohd Taib, S.H.; Shameli, K.; Moozarm Nia, P.; Etesami, M.; Miyake, M.; Rasit Ali, R.; Abouzari-Lotf, E.; Izadiyan, Z. Electrooxidation of nitrite based on green synthesis of gold nanoparticles using Hibiscus sabdariffa leaves. J. Taiwan Inst. Chem. Eng. 2018, 95, 616-626. [CrossRef]

446. Ouellette, M.; Masse, F.; Lefebvre-Demers, M.; Maestracci, Q.; Grenier, P.; Millar, R.; Bertrand, N.; Prieto, M.; Boisselier, E. Insights into gold nanoparticles as a mucoadhesive system. Sci. Rep. 2018, 8, 14357. [CrossRef] [PubMed]

447. Choi, K.H.; Nam, K.C.; Lee, S.Y.; Cho, G.; Jung, J.S.; Kim, H.J.; Park, B.J. Antioxidant Potential and Antibacterial Efficiency of Caffeic Acid-Functionalized ZnO Nanoparticles. Nanomaterials 2017, 7, 148. [CrossRef]

448. Valgimigli, L.; Baschieri, A.; Amorati, R. Antioxidant activity of nanomaterials. J. Mater. Chem. B 2018, 6, 2036-2051. [CrossRef] [PubMed]

449. Baschieri, A.; Amorati, R.; Benelli, T.; Mazzocchetti, L.; D’Angelo, E.; Valgimigli, L. Enhanced Antioxidant Activity under Biomimetic Settings of Ascorbic Acid Included in Halloysite Nanotubes. Antioxidants 2019, 8, 30. [CrossRef] [PubMed]

450. Massaro, M.; Riela, S.; Guernelli, S.; Parisi, F.; Lazzara, G.; Baschieri, A.; Valgimigli, L.; Amorati, R. A synergic nanoantioxidant based on covalently modified halloysite-trolox nanotubes with intra-lumen loaded quercetin. J. Mater. Chem. B 2016, 4, $2229-2241$. [CrossRef] [PubMed]

451. Manjunath, H.M.; Joshi, C.G. Characterization, antioxidant and antimicrobial activity of silver nanoparticles synthesized using marine endophytic fungus- Cladosporium cladosporioides. Process Biochem. 2019, 82, 199-204. [CrossRef]

452. Catauro, M.; Barrino, F.; Dal Poggetto, G.; Crescente, G.; Piccolella, S.; Pacifico, S. Chlorogenic Acid Entrapped in Hybrid Materials with High PEG Content: A Strategy to Obtain Antioxidant Functionalized Biomaterials? Materials 2019, 12, 148. [CrossRef]

453. Shah, B.R.; Zhang, C.; Li, Y.; Li, B. Bioaccessibility and antioxidant activity of curcumin after encapsulated by nano and Pickering emulsion based on chitosan-tripolyphosphate nanoparticles. Food Res. Int. 2016, 89 (Pt 1), 399-407. [CrossRef]

454. Pu, H.L.; Chiang, W.L.; Maiti, B.; Liao, Z.X.; Ho, Y.C.; Shim, M.S.; Chuang, E.Y.; Xia, Y.; Sung, H.W. Nanoparticles with dual responses to oxidative stress and reduced ph for drug release and anti-inflammatory applications. ACS Nano 2014, 8, $1213-1221$. [CrossRef]

455. Talelli, M.; Barz, M.; Rijcken, C.J.; Kiessling, F.; Hennink, W.E.; Lammers, T. Core-Crosslinked Polymeric Micelles: Principles, Preparation, Biomedical Applications and Clinical Translation. Nano Today 2015, 10, 93-117. [CrossRef]

456. Kwon, G.S.; Kataoka, K. Block copolymer micelles as long-circulating drug vehicles. Adv. Drug Deliv. Rev. 2012, 64, 237-245. [CrossRef]

457. Biswas, S.; Kumari, P.; Lakhani, P.M.; Ghosh, B. Recent advances in polymeric micelles for anti-cancer drug delivery. Eur. J. Pharm. Sci. 2016, 83, 184-202. [CrossRef]

458. Mitchell, M.J.; Billingsley, M.M.; Haley, R.M.; Wechsler, M.E.; Peppas, N.A.; Langer, R. Engineering precision nanoparticles for drug delivery. Nat. Rev. Drug Discov. 2021, 20, 101-124. [CrossRef]

459. El Jundi, A.; Buwalda, S.J.; Bakkour, Y.; Garric, X.; Nottelet, B. Double hydrophilic block copolymers self-assemblies in biomedical applications. Adv. Colloid Interface Sci. 2020, 283, 102213. [CrossRef] 